\begin{abstract}
Universidade de São Paulo
Faculdade de Medicina de Ribeirão Preto

Programa de Pós-Graduação em Genética
\end{abstract}

Regulação da expressão gênica pelo fosfato no fungo filamentoso Neurospora crassa.

Diana Ester Gras

Orientador: Antonio Rossi Filho

Ribeirão Preto 2008 


\author{
Universidade de São Paulo \\ Faculdade de Medicina de Ribeirão Preto \\ Programa de Pós-Graduação em Genética
}

Regulação da expressão gênica pelo fosfato no fungo filamentoso Neurospora crassa.

Diana Ester Gras

Orientador: Antonio Rossi Filho

Tese apresentada ao programa de Pós-Graduação em Genética da Faculdade de Medicina de Ribeirão Preto da Universidade de São Paulo para obtenção do título de Doutor em Ciências, Área de concentração: Genética.

Ribeirão Preto 2008 


\section{GRAS, Diana Ester.}

Regulação da expressão gênica pelo fosfato no fungo filamentoso Neurospora crassa. Ribeirão Preto, 2008.

94 pp. :il.; $30 \mathrm{~cm}$

Tese apresentada à Faculdade de Medicina de Ribeirão Preto, Universidade de São Paulo, como requisito parcial para obtenção do grau de Doutor em Ciências, área de concentração: Genética.

Orientador: Rossi Filho, Antonio.

1. Neurospora crassa, 2. expressão gênica, 3. fosfato inorgânico, 4. nuc-2; 5. mak-2. 
Dedico, A meus pais e a Raúl, pelo amor, carinho e dedicação. A distância somente aumentou a admiração e o amor que sinto por vocês. 


\section{Agradecimentos}

Ao meu orientador, Prof. Dr. Antonio Rossi Filho, pela oportunidade de desenvolver este projeto, pela imensa generosidade, compreensão nos momentos difíceis, excelente orientação, e especialmente, pelo carinho e amizade.

À minha co-orientadora, Profa. Dra. Nilce Maria Martinez Rossi, pela permissão total para uso da estrutura de seu laboratório, pela dedicação constante, valiosas críticas, discussões científicas e sugestões, e pelo carinho dispensado;

Ao Prof. Dr. Eduardo Reis, Ana Tahira e a todos do Laboratório de Genômica e Expressão Gênica em Câncer do Instituto de Química (IQ) da USP, pela colaboração nos ensaios de microarranjos de oligonucleotídeos;

Ao Prof. Dr. Rolf A. Prade, do Department of Microbiology and Molecular Genetics Oklahoma State University (USA), pelo material enviado para os ensaios de microrranjos, pelas frutíferas discussões científicas, e pelos momentos divertidos compartilhados;

À minha querida amiga Nalu, uma grande parceira que não mede esforços para me ajudar. Agradeço pela sua amizade, pela linda família que me deu no Brasil, pelo seu bom humor e palavras de incentivo;

À minha amiga e revisora ortográfica María Sol, pela sincera amizade, pela paciência e companheirismo durante todos estes anos;

Ao meu colega e amigo Henrique que me deu a mão nos primeiros passos desta tese, pela ajuda durante diversos experimentos e pelo trabalho conjunto;

À Rodrigo, Emiliana e Janaina que sempre estiveram disponíveis para me ajudar, pela amizade e momentos inesquecíveis;

Aos amigos e companheiros de laboratório: Luciene, Fernanda Paião, Rodrigo, Henrique, Fernando, Jeny, Nalu, Fernanda Maranhão, Emiliana, Juliana Leal, Janaína, Carlos, Juliana Falcão, Fábio, Vivian, Ernna e Niege, agradeço pelo convívio, colaboração e amizade; 
Aos funcionários Roseli, Mendelson, Marcos e Ana Claudia do Laboratório de Genética e Biologia Molecular de Microrganismos do Departamento de Genética, pela dedicação, auxílio técnico, paciência e amizade;

Ao analista de sistemas do Departamento de Genética Pablo, pelo auxílio durante as análises de bioinformática e amizade;

À funcionária Silvia do Laboratório de Bioquímica e Biologia Molecular de Fungos do Departamento de Bioquímica e Imunologia, pela dedicação, carinho e preocupação em deixar todo o material pronto cada vez que precisei;

As secretárias do Departamento de Genética Maria Aparecida, Susie, Ana Claudia, Silvia e Cleusa pela atenção e auxílio prestados;

À Comissão de Pós-Graduação da Faculdade de Medicina de Ribeirão Preto da Universidade de São Paulo;

À Fundação de Amparo a Pesquisa do Estado de São Paulo (FAPESP) pela bolsa concedida e recursos da reserva técnica (Proc. Nro. 04/07316-4), essenciais para a realização desta tese;

À CAPES, CNPq e FAEPA pelos auxílios concedidos. 


\section{SUMÁRIO}

ÍNDICE DE FIGURAS ................................................................................................. iii

ÍNDICE DE TABELAS ..................................................................................................... vii

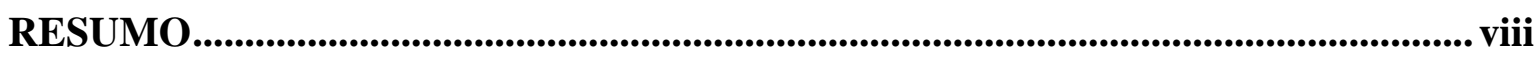

ABSTRACT ….................................................................................................................... $\mathrm{x}$

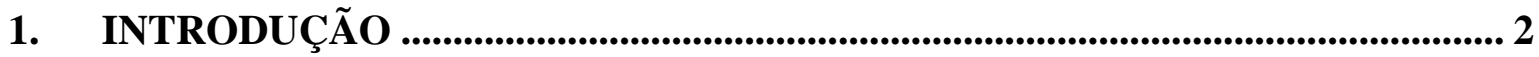

1.1. Fungos como modelos biológicos - resposta adaptativa e aquisição

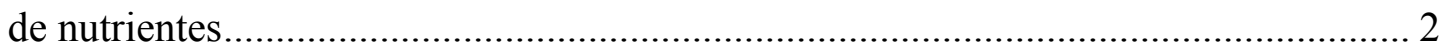

1.2. Técnicas de análise de expressão diferencial de genes................................................. 9

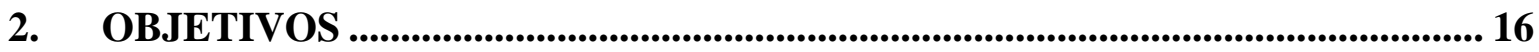

3. MATERIAL E MÉTODOS ................................................................................. 18

3.1. Linhagens de Neurospora crassa ....................................................................... 18

3.2. Manutenção e estoque das linhagens......................................................................... 18

3.3. Construção das bibliotecas de subtração de cDNAs .................................................... 20

3.3.1. Condições de cultivo para os experimentos de expressão gênica ………….... 20

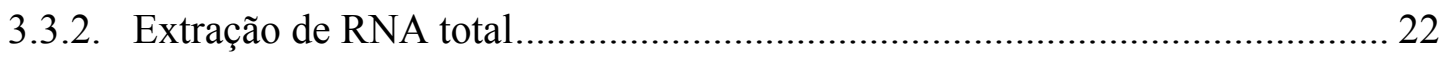

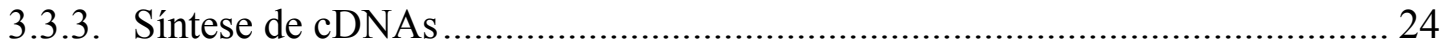

3.3.4. Purificação dos cDNAs dupla fita ………………………………………..... 26

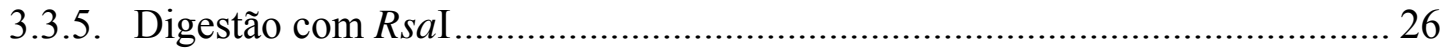

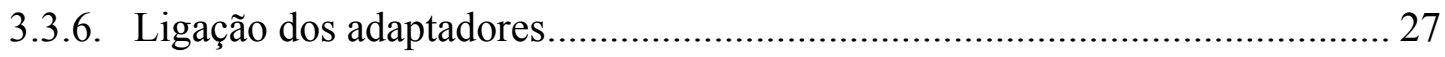

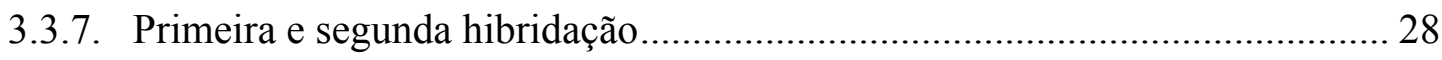

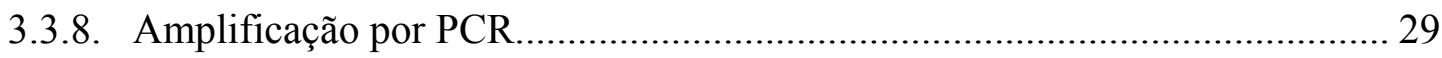

3.3.9. Clonagem dos fragmentos de cDNAs obtidos nas bibliotecas de subtração.. 30

3.3.10. Rastreamento por Northern blot reverso ....................................................... 33

3.3.11. Seqüenciamento das ESTs diferencialmente expressas................................... 35

3.3.12. Análise e anotação das ESTs de $N$. crassa ..................................................... 37

3.3.13. Confirmação dos genes diferencialmente expressos ......................................... 37

3.4. Análise da expressão gênica por microarranjos de oligonucleotídeos ......................... 40

3.4.1. Cultivo em meio líquido de Fries ............................................................... 40

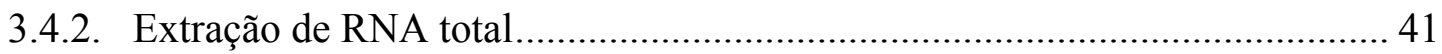


3.4.3. Lâminas de microarranjos de oligonucleotídeos

3.4.4. Marcação das sondas complexas de cDNA com fluorocromos Cy3 e Cy5 ... 42

3.4.5. Quantificação do CyDye incorporado ao cDNA ........................................... 42

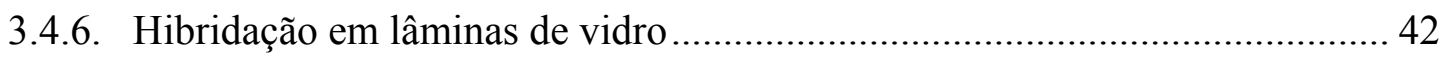

3.4.7. Filtragem e normalização dos dados de expressão gênica ............................. 44

4. RESULTADOS E DISCUSSÃO ................................................................................ 47

4.1. Identificação de genes diferencialmente expressos na linhagem mutante nuc-2A de Neurospora crassa através de SSH ..................................................... 47

4.1.1. Construção das bibliotecas de subtração de cDNAs .................................... 47

4.1.1.1. Confirmação da integridade do RNA total .................................... 48

4.1.1.2. Rastreamento das bibliotecas de subtração ..................................... 50

4.1.2. Análise por bioinformática dos clones selecionados ................................... 52

4.1.3. Validação dos genes reprimidos na linhagem mutante nuc-2A de $N$. crassa

4.1.3.1. Transcritos regulados por nuc-2 em função do nível exógeno de Pi

4.1.4. Validação de genes induzidos na linhagem mutante nuc-2A de $N$.

crassa.....

4.2. Identificação de genes expressos em resposta ao Pi e análise do envolvimento de

MAK-2 no monitoramento do Pi extracelular em Neurospora crassa 68

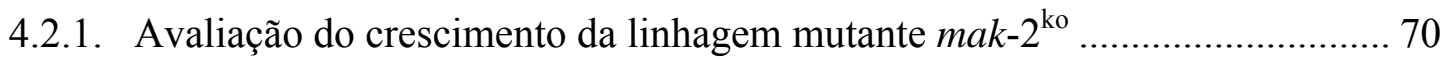

4.2.2. Confirmação da integridade do RNA total .................................................. 72

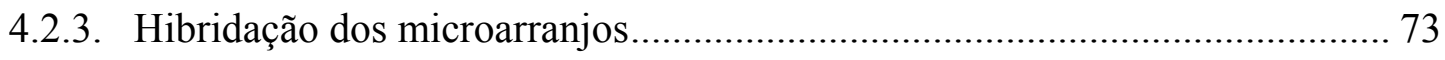

4.2.4. Avaliação da qualidade das hibridações........................................................ 74

4.2.5. Identificação de genes diferencialmente expressos ...................................... 76

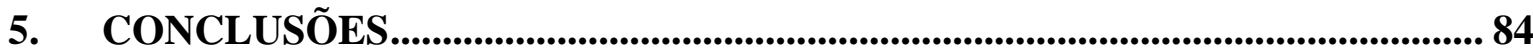

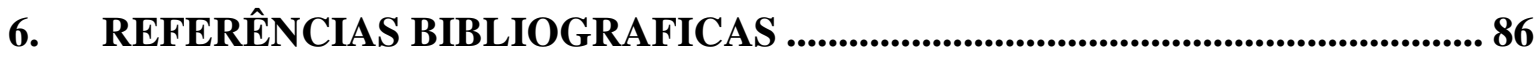

\section{ANEXOS}




\section{ÍNDICE DE FIGURAS}

Figura 1. Modelo da regulação da aquisição de fosfato em N. crassa (Metzenberg, 1979; modificado por Leal et al., 2007). Ativação e inibição são representadas pelos sinais positivos $(+)$ e negativos (-), respectivamente. As linhas pontilhadas representam a ação do Pi ou de genes através de vias metabólicas ainda não elucidadas

4

Figura 2. Representação esquemática da metodologia de biblioteca de subtração de cDNA. Modificada do manual PCR-Select ${ }^{T M} c D N A$ Subtraction kit (BD Biosciences-Clontech, EUA)

Figura 3. Ilustração dos métodos de marcação de sondas complexas de cDNA para microarranjos. A) Método fluorescente usando Cy3 e Cy5 e lâmina de vidro e B) Método radiativo usando ${ }^{33} \mathrm{P}$ e membranas de náilon. Modificada de Sakamoto-Hojo et al. (2003) 13

Figura 4. Modelo de análise do perfil de expressão gênica das linhagens selvagem e mutante $m a k-2^{\mathrm{ko}}$, cultivadas em baixa $(\downarrow)$ e alta $(\uparrow)$ concentrações de Pi 40

Figura 5. Representação esquemática das hibridações realizadas. Amostras da linhagem selvagem em condições de alto Pi $(15 \mathrm{mM})$ e da linhagem selvagem em condições de baixo Pi $(10 \mu \mathrm{M})$ foram marcadas com fluorocromos distintos (Cy3 ou Cy5) e hibridadas na mesma lâmina (Réplica A). Foi realizada também uma segunda hibridação em outra lâmina (Réplica B), na qual os fluorocromos foram invertidos (dye-swap) 
Figura 6. (A) Digestão do cDNA isolado das linhagens selvagem St.L.74A e mutante nuc-2A com enzima RsaI. (1-2) cDNAs da linhagem St.L.74A antes e após a digestão, respectivamente; (3-4) cDNAs da linhagem nuc-2A antes e após a digestão, respectivamente. $\mathrm{M}=$ Padrão de massa molecular: $1 \mathrm{~Kb}$ DNA Ladder (Invitrogen). (B) Produto do PCR supressivo das SSHs. (1) Amplificação de genes induzidos pela proteína NUC-2; (2) Amplificação de genes reprimidos pela proteína NUC-2. $\mathrm{M}=$ Padrão de massa molecular: $1 \mathrm{~Kb}$ Plus DNA Ladder (Invitrogen) 49

Figura 7. Eletroforese em gel de agarose $(1,2 \%)$ dos produtos de PCR, mostrando o tamanho dos insertos de uma amostra de clones oriundos da biblioteca NUC-2 I. $\mathrm{M}=$ Padrão de massa molecular: $1 \mathrm{~Kb}$ DNA Ladder (Invitrogen) 50

Figura 8. Northern blot reverso. Membranas arranjadas com produto de PCR amplificado de 96 clones positivos no primeiro rastreamento da biblioteca NUC-2 I, hibridadas com sonda St.L.74A: cDNA subtraído a partir da linhagem St.L.74A cultivada sob baixo Pi; e com sonda nuc-2A: cDNA subtraído a partir da linhagem nuc-2A cultivada sob baixo Pi. 51

Figura 9. Northern blot reverso. Membranas arranjadas com produto de PCR amplificado de 66 clones positivos no primeiro rastreamento da biblioteca NUC-2 R, hibridadas com sonda St.L.74A: cDNA subtraído a partir da linhagem St.L.74A cultivada sob baixo Pi; e com sonda nuc-2A: cDNA subtraído a partir da linhagem nuc-2A cultivada sob baixo Pi. 52 
Figura 10. Confirmação por Northern blot dos genes reprimidos na linhagem mutante nuc-2A. (1) RNA da linhagem selvagem cultivada em condições Pi-limitante; (2) RNA da linhagem mutante nuc-2A cultivada em condições de Pilimitante. RNA ribossomal foi visualizado com brometo de etídio para comparação das quantidades utilizadas. Os gráficos indicam a intensidade relativa dos sinais de hibridação das marcações mostradas por Northern blot de alguns genes expressos na linhagem selvagem (barra 1) e mutante nuc-2A (barra 2), como estabelecido por análise densiométrica. 58

Figura 11. Confirmação da expressão dos genes induzidos na linhagem mutante nuc-2A. (A) Análise por Northern blot virtual. (1) cDNA da linhagem selvagem; (2) cDNA da linhagem mutante nuc-2A. (B) Análise por Northern blot. (1) RNA da linhagem selvagem cultivada em condições de baixo Pi; (2) RNA da linhagem mutante nuc-2A cultivada em condições de baixo Pi; (3) RNA da linhagem selvagem cultivada em condições de alto Pi. As bandas de RNA ribossomal foram mostradas para controle da quantidade de RNA colocada em cada poço

Figura 12. Análise da expressão do gene mak-2 por Northern blot. As bandas de RNA ribossomal foram mostradas para controle da quantidade de RNA colocada em cada poço 70

Figura 13. Fenótipos das linhagens selvagem (St.L.74A) e mutante $m a k-2^{\text {ko }}$ de N. crassa

Figura 14. Cultivo das linhagens selvagem (St.L.74A) e mutante $m a k-2^{\mathrm{ko}}$ por 5 horas a $30^{\circ} \mathrm{C}$ em meio liquido de Fries 72 
Figura 15. Eletroforese pela tecnologia Agilent mostrando o fracionamento das amostras de RNA total. (1-4) RNA da linhagem St.L.74A cultivada em condições de Pi-limitante; (5-8) RNA da linhagem St.L.74A cultivada em condições de Pisaturante; (9-12) RNA da linhagem mutante mak-2 ${ }^{\mathrm{ko}}$ cultivada em condições de Pi-limitante. $\mathrm{M}=$ Padrão de massa molecular 73

Figura 16. Imagem representativa das hibridações de microarranjos de N. crassa. Lâmina onde a linhagem selvagem cultivada com baixa concentração de Pi foi marcada com Cy3 dUTP (verde) e a linhagem selvagem cultivada com alta concentração de Pi foi marcada com Cy5 dUTP (vermelho)

Figura 17. Genes diferencialmente expressos como mostrado pelo programa SAM. Resultados das comparações entre a distância observada d(i) e esperada $d_{E}(i)$ dos dados referentes aos experimentos de microarranjos da linhagem St.L.74A cultivada em condições de Pi-limitante $(10 \mu \mathrm{M})$ ou Pi-saturante $(15 \mathrm{mM})$. A linha azul contínua indica a região onde $d(i)=d_{E}(i)$. As linhas tracejadas são cortes a uma distância $\Delta$ da linha contínua. Os pontos verdes representam genes que se afastam da linha $\mathrm{d}(\mathrm{i})=\mathrm{d}_{\mathrm{E}}(\mathrm{i})$ a uma distância $<\Delta$; já os pontos vermelhos representam genes que se afastam da linha $d(i)=d_{E}(i)$, mas a uma distancia $>\Delta$

Figura 18. Genes diferencialmente expressos como mostrado pelo programa SAM. Resultados das comparações entre a distância observada d(i) e esperada $d_{E}(i)$ dos dados referentes aos experimentos de microarranjos entre as linhagens selvagem e mutante mak-2 $2^{\mathrm{ko}}$ cultivadas em condições de Pi-limitante $(10 \mu \mathrm{M})$ e $\mathrm{pH}$ ácido $(5,4)$. A linha azul contínua indica a região onde $\mathrm{d}(\mathrm{i})=\mathrm{d}_{\mathrm{E}}(\mathrm{i})$. As linhas tracejadas são cortes a uma distância $\Delta$ da linha contínua. Os pontos verdes representam genes que se afastam da linha $d(i)=d_{E}(i)$ a uma distância $<\Delta$; já os pontos vermelhos representam genes que se afastam da linha $\mathrm{d}(\mathrm{i})=$ $\mathrm{d}_{\mathrm{E}}(\mathrm{i})$, mas a uma distancia $>\Delta$ 78 


\section{ÍNDICE DE TABELAS}

Tabela 1. Estratégia usada para a construção das bibliotecas subtrativas de cDNA ...... 47

Tabela 2. Genes com expressão diminuída na linhagem mutante nuc-2A cultivada em Pi-limitante $(10 \mu \mathrm{M})$ e pH ácido (pH 5,4)

Tabela 3. Genes com elevada expressão na linhagem mutante nuc-2A cultivada em Pilimitante $(10 \mu \mathrm{M})$ e pH ácido $(\mathrm{pH} 5,4)$ 56

Tabela 4. Matriz de coeficiente de correlação de Pearson das medidas de intensidade de todos os experimentos marcados com Cy5. Em preto, as correlações entre réplicas biológicas, e em cinza, as correlações entre amostras diferentes...... 75

Tabela 5. Matriz de coeficiente de correlação de Pearson das medidas de intensidade de todos os experimentos marcados com $\mathrm{Cy} 3$. Em preto, as correlações entre réplicas biológicas, e em cinza, as correlações entre amostras diferentes...... 76 


\section{RESUMO}

\section{Regulação da expressão gênica pelo fosfato no fungo filamentoso Neurospora crassa.}

A regulação da expressão gênica é vital para todos os organismos se adaptarem rapidamente às mudanças ambientais. Estes mecanismos adaptativos são altamente complexos e a maioria deles não está completamente esclarecida. $\mathrm{O}$ fosfato inorgânico (Pi), um nutriente essencial para todos os organismos, é requerido em importantes processos celulares como a biosíntese de ácidos nucléicos e a sinalização metabólica. $\mathrm{O}$ sistema de aquisição de Pi no fungo filamentoso Neurospora crassa inclui pelo menos quatro genes regulatórios: nuc-2, preg, pgov e nuc-1. Em condições limitantes de Pi, NUC2, uma proteína com domínio de repetição de anquirina, inibe o funcionamento do complexo PREG-PGOV, ativando assim o fator de transcrição NUC-1 e a expressão de genes envolvidos na captação de fosfato, como fosfatases, fosfato permeases e nucleases. Visando entender a funcionalidade do gene $n u c-2$ na regulação da expressão gênica em resposta aos níveis de Pi exógeno, foram construídas duas bibliotecas de subtração de cDNA entre as linhagens selvagem St.L.74A e nuc-2A de N. crassa, cultivadas em Pilimitante. Obtivemos 52 transcritos induzidos e 16 reprimidos pela proteína NUC-2. A categorização funcional destas sequências revelou genes envolvidos em diversos processos celulares, como transporte, regulação transcricional, transdução de sinal, metabolismo, síntese protéica e desenvolvimento. Entre os genes modulados negativamente pela proteína NUC-2, foi identificado um gene que codifica a proteína MAK-2 (mitogen-activated protein kinase-2), envolvida em vias de sinalização intracelular. O papel funcional deste gene no monitoramento do $\mathrm{Pi}$ extracelular foi avaliado por microarranjos de 
oligonucleotídeos, comparando as linhagens selvagem e mutante mak-2, cultivadas em baixa concentração de Pi. Foram identificados 4.214 genes regulados pela proteína MAK2, dentre eles a ciclina codificada pelo gene preg. Além disto, genes regulados em função da concentração de Pi foram identificados, mostrando o envolvimento de 3.174 transcritos. Os resultados obtidos neste trabalho revelam novos aspectos moleculares envolvidos na adaptação à disponibilidade de Pi extracelular, sugerindo que o gene mak-2 constitui um novo componente da via de sinalização e monitoramento de fosfato em $N$. crassa. 


\section{ABSTRACT \\ Regulation of gene expression by phosphate in the filamentous fungus Neurospora crassa.}

Gene expression regulation is crucial for all organisms to rapidly adapt to environmental changes. These adaptive mechanisms are highly complex and most of them have not been completely elucidated. The inorganic phosphate (Pi), an essential nutrient for all organisms, is required for important cellular processes, such as nucleic acids biosynthesis and metabolic signaling. The Pi acquisition system in the filamentous fungus Neurospora crassa includes at least four regulatory genes: nuc-2, preg, pgov and nuc-1. Under limiting $\mathrm{Pi}$ conditions, NUC-2, an ankyrin-like repeat protein, inhibits the functioning of the PREG-PGOV complex, allowing the activation of the transcription factor NUC-1 and the expression of genes involved in phosphate acquisition, such as phosphatases, phosphate permeases and nucleases. Aiming at a better comprehension of the nuc-2 functionality in gene expression regulation in response to exogenous Pi levels, two cDNA subtraction libraries were constructed comparing N. crassa wild type St.L.74A and nuc-2A strains, grown under Pi starvation. We obtained 52 NUC-2 up- and 16 downregulated genes. Functional categorization of these sequences revealed genes involved in several cellular processes, such as cellular transport, transcriptional regulation, metabolism, protein synthesis and development. Among the NUC-2 negatively modulated genes, we identified the MAK-2 (mitogen-activated protein kinase-2) protein coding gene, involved in the intracellular signaling pathway. The functional role of this gene in the extracellular Pi sensing was evaluated by oligonucleotide microarrays, comparing wild type and mak-2 strains responses under Pi starvation. We identified 4.214 MAK-2 regulated genes, among them the cyclin coding gene, preg. Furthermore, 3.174 genes 
regulated in response to Pi levels were identified. In a nutshell, the results obtained in this work reveal novel molecular aspects of the adaptation to extracellular Pi availability, suggesting that the mak-2 gene constitutes a novel component of the N. crassa phosphate sensing and signaling pathway. 
INTRODUÇÃO 


\section{I NTR O D U Ç Ã O}

\subsection{Fungos como modelos biológicos - resposta adaptativa e aquisição de nutrientes}

Varias espécies de fungos têm sido alvos de estudos genéticos, bioquímicos e de biologia molecular, tornando-se, ao longo do tempo modelos biológicos de organismos eucariotos para o estudo de mecanismos envolvidos na divisão e diferenciação celular, regulação da expressão gênica, adaptabilidade ao ambiente, entre outros processos celulares. A facilidade de manipulação genética e o curto ciclo de vida, aliados às exigências nutricionais simples, disponibilidade de ferramentas genômicas e moleculares e, principalmente ao genoma recentemente seqüenciado e analisado, têm definido a escolha de Neurospora crassa como referência para fungos filamentosos e outros eucariotos multicelulares (Davis, 2000; Galagan et al., 2003).

A adaptação às mudanças ambientais como temperatura, salinidade, valores extremos de $\mathrm{pH}$, além de oscilações na disponibilidade de nutrientes como fontes de carbono, nitrogênio e fosfato, têm um papel fundamental na sobrevivência dos microrganismos. N. crassa e outros fungos modelos, como Saccharomyces cerevisiae e Aspergillus nidulans, são utilizados no estudo da resposta adaptativa à limitação de fosfato inorgânico e variações do pH extracelular (Peleg et al., 1996a; Denison, 2000; Nozawa et al., 2000a; Wu et al., 2004; Mouillon e Persson, 2006; Silva et al., 2008). A regulação molecular dessas respostas adaptativas revelou-se extremamente complexa, envolvendo vários genes que monitoram a disponibilidade de fosfato inorgânico, bem como as alterações de pH extracelular, sinalizando para a síntese de macromoléculas necessárias para manutenção da homeostase celular (Kang e Metzenberg, 1990; Huang et al., 2001; Knight et al., 2004; Waters et al., 2004). 
O fosfato inorgânico (Pi) é um nutriente essencial para todos os organismos, sendo necessário tanto para a estrutura celular como para o transporte de energia, síntese de ácidos nucléicos e crescimento celular (Paytan e McLaughlin, 2007). Assim, a assimilação de fosfato do ambiente, em procariotos e em eucariotos primitivos, é um dos processos mais importante de aquisição de nutrientes (Furukama et al., 1987). Quando N. crassa é cultivado em meio contendo quantidades limitantes de Pi, ou com ácidos nucléicos como única fonte de Pi, diversas enzimas são sintetizadas com a finalidade de disponibilizar mais fosfato para a célula (Lehman et al., 1973; Lowendorf e Slayman, 1975). Nestas condições o fungo sintetiza mais de 10 enzimas intracelulares e/ou extracelulares Pi-repressíveis que incluem nucleases, fosfatases e permeases (Hasunuma, 1983).

Os mecanismos genéticos e moleculares que coordenam a síntese das enzimas envolvidas no sistema de aquisição de Pi foram estabelecidos em $N$. crassa através de estudos genéticos e bioquímicos, e incluem pelo menos quatro genes regulatórios: nuc-1, nuc-2, preg e pgov (Metzenberg, 1979). De acordo com esse modelo, a ação do produto do gene nuc-1 permite a expressão de genes estruturais envolvidos na captação de Pi. A ação de NUC-1 é antagonizada pelos produtos dos genes preg e pgov, os quais são antagonizados pelo produto do gene nuc-2. NUC-2 é o componente que transmite o sinal de ativação desse circuito regulatório e sua ação é inativada pelo Pi ou um co-repressor derivado dele. Sendo assim, em baixa concentração de Pi, NUC-2 inibe o funcionamento do complexo PREG-PGOV, ativando assim o fator de transcrição NUC-1 e a expressão de fosfatases ácida e alcalina, fosfato permeases e nucleases, entre outras (Figura 1) (Metzenberg, 1979; Peleg et al., 1996 a,b; Leal et al., 2007). 


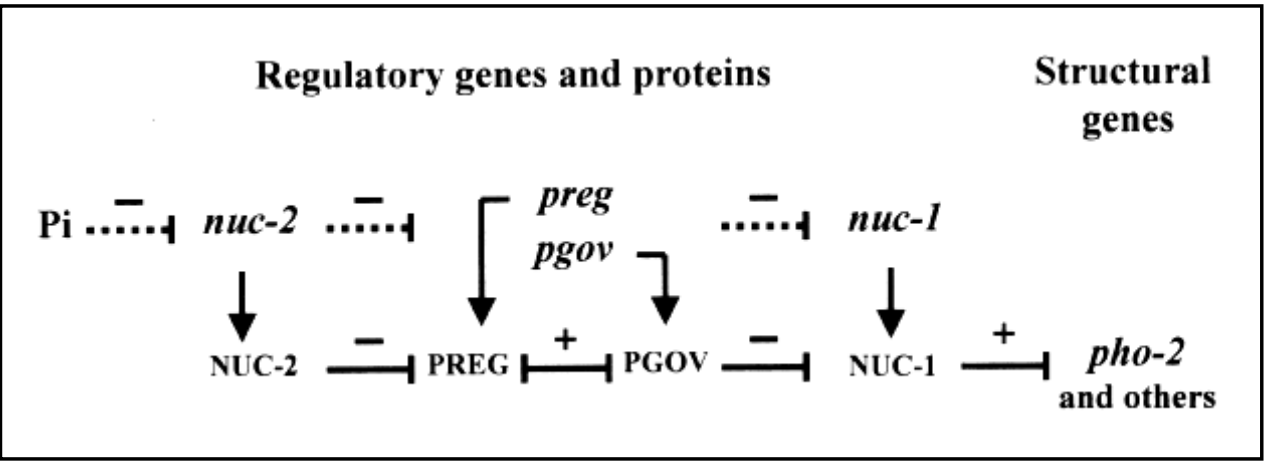

Figura 1. Modelo da regulação da aquisição de fosfato em N. crassa (Metzenberg, 1979; modificado por Leal et al., 2007). Ativação e inibição são representadas pelos sinais positivos (+) e negativos (-), respectivamente. As linhas pontilhadas representam a ação do Pi ou de genes através de vias metabólicas ainda não elucidadas.

Uma regulação hierárquica deste tipo implica que: i) uma mutação no gene nuc-2 exiba o mesmo fenótipo que uma mutação nuc-1, incluindo a impossibilidade de utilizar ácidos nucléicos (DNA ou RNA) como fonte de fosfato; ii) em presença de uma concentração suficiente de $\mathrm{Pi}$, o mutante $\mathrm{preg}^{\mathrm{c}}$ (linhagem que expressa constitutivamente fosfatases) sintetize e secrete as mesmas enzimas que a linhagem selvagem quando cultivada sob quantidades limitantes de Pi. Além disso, outros fatores fisiológicos, podem afetar a expressão e/ou a secreção das enzimas envolvidas na aquisição de fosfato. Alguns estudos mostraram que o pH extracelular é determinante para a secreção das fosfatases Pirepressíveis, como a fosfatase alcalina, codificada pelo gene pho-2 (Grotelueschen et al., 1994), a qual é retida no micélio em pH 5,4 e secretada quando o pH do meio é 8,0 (Nahas et al., 1982; Nozawa et al., 2002b).

As proteínas NUC-2, PREG e NUC-1 apresentam similaridade, respectivamente, com as proteínas $\mathrm{PHO} 81, \mathrm{PHO} 80, \mathrm{PHO} 4$ e $\mathrm{PHO} 2$ pertencentes ao sistema de aquisição de Pi de S. cerevisiae, sendo que NUC-1 tem similaridade com PHO4 e PHO2 (Persson et al., 2003; Oshima, 1991; Kang e Metzenberg, 1990). A proteína PGOV ainda não foi 
caracterizada funcionalmente, porém é sugerido que a mesma apresenta similaridade à quinase dependente de ciclina (CDK) PHO85, a qual forma um complexo com a ciclina PHO80, responsável pela fosforilação de PHO4 e PHO2 (Kang e Metzenberg, 1993; Liu et al., 2000; Mouillon et al., 2006). Em A. nidulans, entre os genes identificados como homólogos àqueles pertencentes ao sistema de aquisição de Pi em $N$. crassa e $S$. cerevisiae, somente dois deles, An-Pho80 e palcA, possuem uma função conservada em relação a seus ortólogos preg e nuc-1 em $N$. crassa e pho80 e pho4 em S. cerevisiae, respectivamente (Wu et al., 2004).

O gene nuc-1 é expresso constitutivamente, independente das concentrações de Pi. A atividade da proteína NUC-1, composta por 842 aminoácidos, é positivamente regulada em condições de Pi-limitante, promovendo a ativação de pho-2 (fosfatase alcalina Pirepressível) (Grotelueschen et al., 1994), pho-4 e pho-5 (fosfato permeases) (Mann et al., 1989; Versaw, 1995). A região carboxi-terminal de NUC-1 possui um domínio funcional contendo um motivo de ligação ao DNA do tipo hélice-volta-hélice (helix-loop-helix HLH), presente em um grande número de fatores de transcrição envolvidos numa variedade de processos celulares, incluindo diferenciação, desenvolvimento, proliferação celular e resposta ao estresse (Peleg e Metzenberg, 1994; Chen e Lopes, 2007). Proteínas HLH ligam-se às seqüências consenso 5'-CANNTG-3' (seqüência típica CACGTG) presentes no DNA, formando homodímeros ou heterodímeros em combinações com outras proteínas HLH (Peleg e Metzenberg, 1994; Chen e Lopes, 2007). NUC-1 é considerada uma proteína HLH atípica, pois apresenta algumas diferenças estruturais dos outros fatores de transcrição HLH. NUC-1 apresenta um domínio adicional de dimerização constituído por um motivo zíper, identificado também em outras proteínas HLH, as quais foram classificadas como proteínas HLH/Z (Dang e Lee, 1989). Porém, o motivo zíper 
identificado em NUC-1 apresenta repetições de alanina e metionina, e não resíduos de leucina como normalmente encontrados nas proteínas HLH/Z. Além disso, a região entre as duas hélices de NUC-1 (região de "volta" ou loop) é maior que aquela observada em outras proteínas HLH. Sugere-se que essa região maior de "volta", constituída por muitos aminoácidos carregados, possua um papel na funcionalidade de NUC-1, provavelmente através de interações eletrostáticas (Peleg e Metzenberg, 1994). Ademais, análises de proteínas NUC-1 mutantes sugerem que os domínios de hélice II e zíper são essenciais para a dimerização da proteína, enquanto que o domínio de hélice I está envolvido na ligação ao DNA (Peleg e Metzenberg, 1994). Outros dois prováveis domínios funcionais foram identificados em NUC-1, estando um deles presente na região potencialmente envolvida na interação com os fatores regulatórios negativos PREG/PGOV (Kang e Metzenberg, 1993). O outro corresponde a regiões ricas em glutamina e prolina, as quais devem participar na ativação transcricional (Kang e Metzenberg, 1990).

Similar a nuc-1, o gene preg, que codifica uma proteína de 483 aminoácidos, não é transcricionalmente regulado pelo Pi. A proteína PREG foi caracterizada como uma ciclina, proteínas funcionalmente conservadas desde leveduras até humanos, que atuam na regulação do ciclo celular e na transcrição, entre outros processos celulares, ativando e adicionando especificidade às CDKs (Andrews e Measday, 1998; Waters et al. 2004; Wu et al. 2004). A análise molecular de PREG revelou a presença de aminoácidos carregados negativamente agrupados preferencialmente na região carboxi-terminal (aminoácidos 433 ao 472), como também a presença de dois resíduos Ser, potenciais regiões de fosforilação. Além disso, foi observada uma alta similaridade de aminoácidos entre as regiões carboxiterminal de PREG (aminoácidos 274 ao 412) e da ciclina PHO80 (aminoácidos 35 ao 173) de S. cerevisiae. Mutações em PHO80 sugerem que essa ciclina interage e regula 
negativamente PHO4 através dessa região conservada. Linhagens mutantes $\operatorname{preg}^{\mathrm{c}}$ de $N$. crassa apresentam mutações de perda de função, caracterizadas por mudanças na matriz de leitura ou substituições de aminoácidos na região conservada entre PREG e PHO80, sugerindo que essa região seja responsável pela interação entre PREG e NUC-1 (Kang e Metzenberg, 1993).

A ligação entre NUC-1 e o complexo ciclina-CDK (PREG-PGOV) ocorre somente quando os níveis de Pi estão altos e, provavelmente essa interação deve promover o seqüestro de NUC-1 para o citosol. Esta interação parece não estar associada à fosforilação de NUC-1 pois, em contraste com o descrito para as proteínas PHO4 e PHO80 de S. cerevisiae, não foram encontradas evidências quanto à fosforilação de NUC-1 por PREG em N. crassa (Peleg et al., 1996b). Outros dois mecanismos de inibição de NUC-1 por PREG foram propostos (Kang e Metzenberg, 1993). Um desses mecanismos baseia-se na dissociação (ou inibição da formação) do dímero que NUC-1 forma para ligar-se ao DNA. O domínio regulatório de NUC-1 apresenta poucos resíduos carregados positivamente, o que gera uma repulsão eletrostática entre o domínio regulatório de NUC-1 e a região ácida carboxi-terminal de PREG. Devido à essa repulsão, a região ácida de PREG forma uma $\alpha$ hélice estendida e rígida que parece não permitir uma interação específica da ciclina com o fator de transcrição NUC-1. Portanto, a dissociação do dímero deve ocorrer devido à repulsão eletrostática entre duas proteínas PREG ligadas aos dois componentes monoméricos. O outro mecanismo sustenta a idéia de que PREG liga-se a NUC-1 formando um complexo, o que deve provocar a dissociação de NUC-1 do DNA devido à repulsão eletrostática entre o complexo carregado negativamente e os grupamentos fosfato presentes na estrutura do DNA. Para os dois mecanismos serem possíveis, é necessário que a interação de PREG com NUC-1 fosse mais forte que a ligação entre os dois polipeptídeos 
NUC-1 no dímero, e mais forte que a interação de NUC-1 ao DNA (Kang e Metzenberg, 1993).

O gene nuc-2 é transcricionalmente regulado em função da disponibilidade de $\mathrm{Pi}$, uma vez que os níveis de transcritos nuc-2 aumentam aproximadamente 15 vezes quando o Pi é limitante. No entanto, análises de expressão de nuc-2 na linhagem mutante nuc- $1^{\mathrm{c}}$ (o complexo PREG-PGOV não inibe a função de NUC-1) mostraram que os níveis de RNAs mensageiros (RNAm) de nuc-2 em condições de Pi-saturante eram similares ao observado na linhagem selvagem cultivada em Pi-limitante, sugerindo que, pelo menos nessa linhagem mutante, a síntese ou a estabilidade dos transcritos de nuc-2 não responde à privação de Pi, e sim a uma proteína NUC-1 ativa (Peleg et al., 1996a).

NUC-2 é uma proteína de 1.066 aminoácidos, e possui um domínio funcional que contém seis repetições de anquirina (Peleg et al., 1996a). Esta proteína apresenta alta similaridade com a seqüência de PHO81, um inibidor de quinase dependente de ciclina (CDKI), o qual forma um complexo estável com PHO80-PHO85 independente dos níveis de Pi. Quando o Pi é limitante, PHO81 inibe esse complexo permitindo o acúmulo de PHO4 não fosforilado no núcleo e conseqüentemente, a ativação de genes envolvidos no sistema de aquisição de Pi (Huang et al., 2001). Os resíduos conservados entre NUC-2 e PHO81 estão presentes principalmente em duas regiões: na porção amino-terminal e nas regiões de repetições de anquirina, localizadas na porção carboxi-terminal e provavelmente envolvidas na interação entre NUC-2 e o complexo PREG-PGOV em condições de Pilimitante (Peleg et al., 1996a).

O domínio protéico de anquirina repetida é um dos mais abundantes na natureza, sendo encontrado em uma ampla variedade de organismos (Andrade et al., 2001). Cada motivo de anquirina apresenta aproximadamente 33 aminoácidos formando uma estrutura 
L-shaped consistente de $2 \alpha$ hélices antiparalelas seguidas por um $\beta$-harpin. Os harpins de diferentes motivos repetidos se empacotam formando um $\beta$-folha antiparalelo (Gorina e Pavletich, 1996). Estes domínios protéicos são extremamente importantes já que participam numa variedade de funções biológicas relevantes, entre elas, inibidores de CDK, reguladores da transcrição, reguladores do desenvolvimento, organizadores do citoesqueleto e toxinas (Sedgwick e Smerdom, 1999; Rubtsov e Lopina, 2000; Andrade et al., 2001; Bennett e Chen, 2001; Mohler et al., 2002; Mosavi et al., 2004).

Embora diversos trabalhos levaram a um progresso na compreensão da resposta adaptativa dos fungos aos níveis de Pi disponível no ambiente, os mecanismos envolvidos na regulação da expressão gênica são complexos, e a maioria deles, assim como os genes regulados por este sistema, ainda não estão totalmente esclarecidos.

\subsection{Técnicas de análise de expressão diferencial de genes}

As proteínas são os componentes de trabalho ativo da maquinaria celular, ao passo que o DNA armazena as informações para sua síntese, a qual é mediada pelos respectivos RNAm. A expressão gênica é essencial para que as células desempenhem diversas funções, incluindo produção de energia, biosíntese de macromoléculas, divisão, manutenção da arquitetura celular, resposta a estímulos do meio e diferenciação. $\mathrm{O}$ conhecimento dos genes expressos por um genoma, bem como seus níveis de expressão em determinada condição, fornecem informações importantes sobre diferentes processos celulares, auxiliando na elucidação da função de genes já caracterizados ou não (Horak e Snyder, 2002). Assim, a genômica funcional é uma das estratégias mais utilizadas atualmente na descoberta e na compreensão de mecanismos moleculares envolvidos em diversos processos biológicos (Martin e Pardee, 2000; Liang e Pardee, 2003), inclusive na 
adaptação dos microrganismos às mudanças no ambiente (Ogawa et al., 2000; Silva et al., 2008).

Várias técnicas foram desenvolvidas para identificar genes diferencialmente expressos, como, análise serial da expressão gênica (serial analysis of gene expression SAGE) (Velculescu et al., 1995), microarranjos de cDNA (cDNA microarrays) (Schena et al., 1995), differential display de RNA mensageiro por reação em cadeia da polimerase (mRNA differentially display reverse trasncription polimerase chain reaction - DDRTPCR) (Liang e Pardee, 1992), e metodologias baseadas na subtração de cDNAs, destacando-se entre elas a hibridação subtrativa supressiva (suppression subtractive hybridization - SSH) (Diatchenko et al., 1996). Cada uma destas técnicas apresenta vantagens e desvantagens. O DDRT-PCR tem como vantagem o fato de ser um processo relativamente rápido, além de permitir comparar mais de duas condições e trabalhar com pequena quantidade de amostra inicial. Entretanto, esta metodologia apresenta um alto índice de falsos positivos, tendo como alvo, geralmente, mRNA de abundância média. Por este motivo, em geral a análise é restrita a apenas uma parcela dos cDNAs. O SAGE permite a avaliar muitas amostras ao mesmo tempo, no entanto exige seqüencimento automatizado em larga escala para se chegar às seqüências pouco expressas, e conhecimento das sequências genômicas para o processo de anotação e identificação das sequências obtidas.

A técnica de SSH é fundamentada no método de PCR supressivo e tem como objetivo isolar e identificar cDNAs com expressão diferencial em uma população de interesse combinando normalização e subtração. O passo de normalização consiste em equalizar a abundância de cDNAs na população teste e o passo de subtração exclui as seqüências comuns entre as duas populações de cDNA (teste e controle). Uma das 
principais vantagens desta metodologia é a possibilidade de identificar transcritos raros, conseqüência do passo de normalização. Outra vantagem é a elevada concentração de cDNAs equalizados, obtida pelo PCR supressivo, o que facilita a clonagem dos cDNAs diferencialmente expressos (Huang et al., 2007). Os passos principais desta técnica são: (i) ambas populações de mRNA são convertidos em cDNA; (ii) os cDNAs de ambas as condições são digeridos com a enzima RsaI; (iii) o cDNA da condição teste é dividido em duas alíquotas, às quais são ligados dois tipos de adaptadores (1 e 2R); (iv) os cDNAs das condições teste e controle são hibridados e as seqüências híbridas são removidas, e assim os cDNAs restantes (não hibridados) constituem os genes expressos unicamente na condição que se quer analisar; (v) estes cDNAs são amplificados por PCR supressivo, enriquecendo a população dos genes diferencialmente expressos na condição teste (Huang et al., 2007) (Figura 2). 


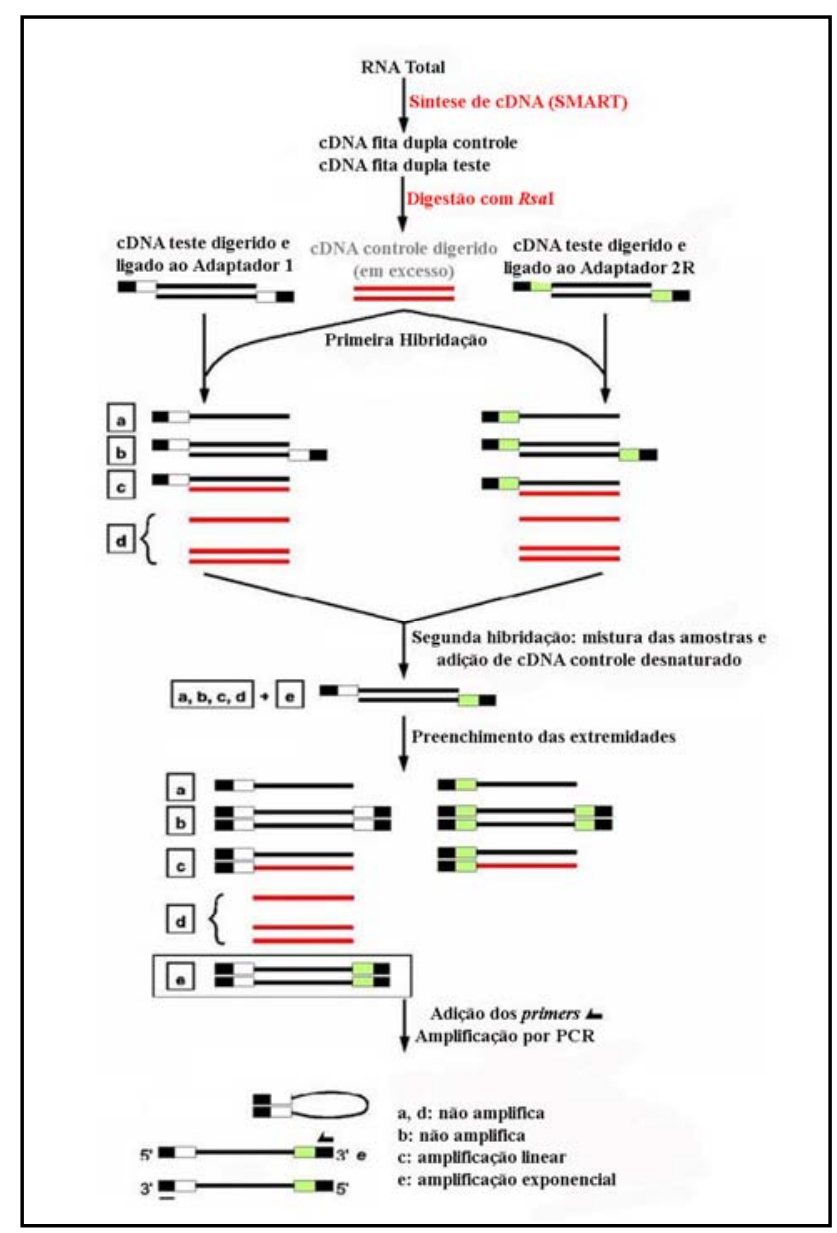

Figura 2. Representação esquemática da metodologia de biblioteca de subtração de cDNA. Modificada do manual PCR-Select ${ }^{T M}$ cDNA Subtraction kit (BD Biosciences-Clontech, EUA).

Outra ferramenta muito difundida para estudos de expressão gênica é a tecnologia de microarranjos de cDNA que permite a caracterização da expressão de milhares de genes. Entretanto, identifica apenas seqüências já conhecidas, além de ser uma metodologia relativamente cara (Soares, 1997; Kozian et al., 1999). Aliando-se a disponibilidade das bibliotecas de cDNA com a robótica de alta precisão na deposição de pequenas amostras em superfícies sólidas, tornou-se possível a preparação dos microarranjos de clones de cDNA, produtos de PCR e oligonucleotídeos em membranas de 
náilon, ou em lâminas de vidro. As sondas utilizadas nas hibridações com os microarranjos (sondas de cDNA derivadas das amostras de RNA em estudo) podem ser marcadas com radioatividade $\left({ }^{33} \mathrm{P}\right)$ quando utiliza-se como plataforma membranas de náilon ou com fluorocromos (Cy3 e Cy5) quando utiliza-se lâminas de vidro (Figura 3).

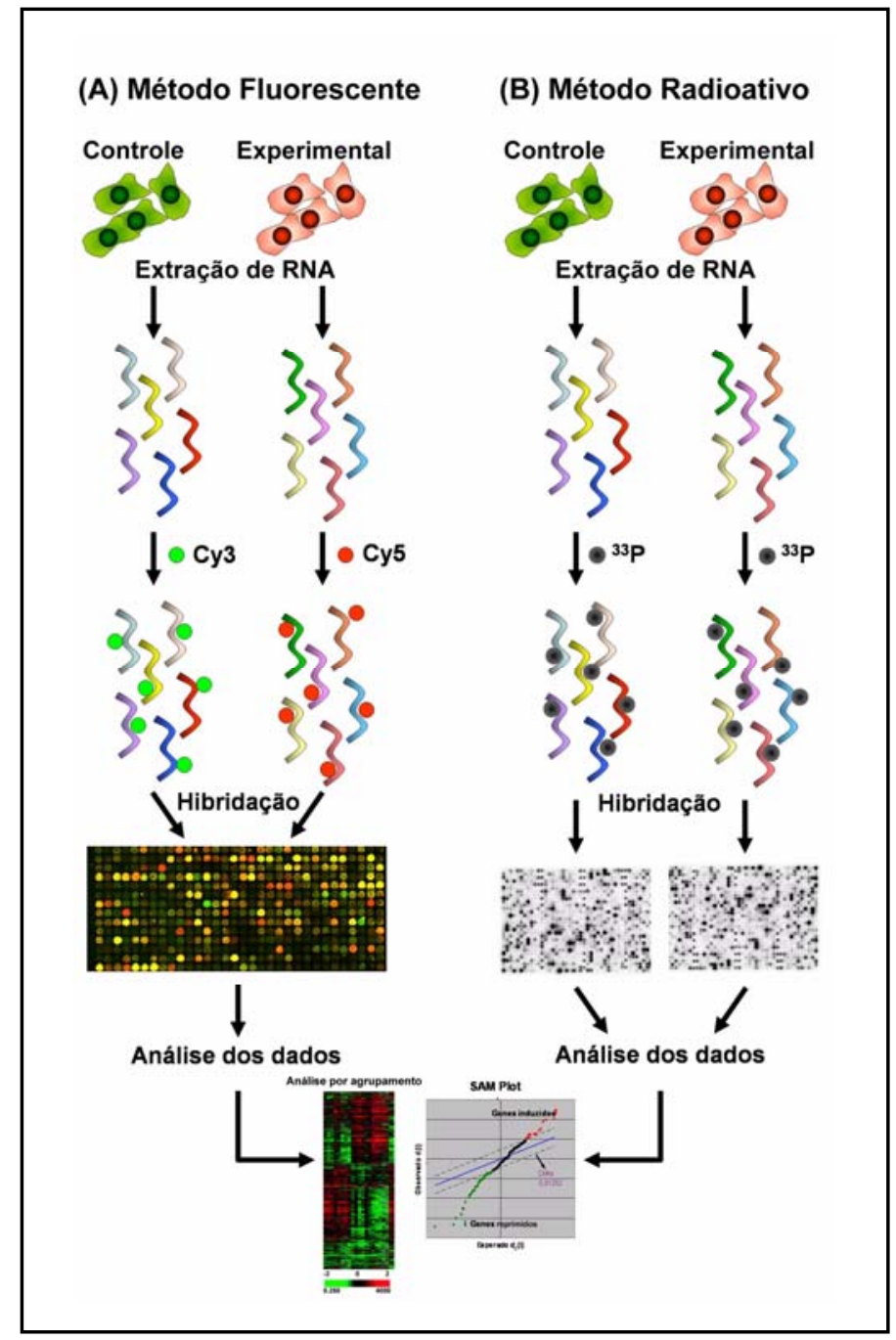

Figura 3. Ilustração dos métodos de marcação de sondas complexas de cDNA para microarranjos. A) Método fluorescente usando Cy3 e Cy5 e lâmina de vidro e B) Método radiativo usando ${ }^{33} \mathrm{P}$ e membranas de náilon. Modificada de Sakamoto-Hojo et al. (2003). 
A utilização de técnicas de análise de expressão gênica diferencial, tem levado a uma maior compreensão da biologia e adaptabilidade de diversos microrganismos. A construção de bibliotecas de subtração de cDNAs tem sido uma importante ferramenta utilizada em estudos de expressão gênica para identificação de genes envolvidos na resposta adaptativa ao $\mathrm{pH}$ em A. nidulans e no dermatófito Trichophyton rubrum (Silveira et al., 2007; Silva et al., 2008). Estudos utilizando estas técnicas também possibilitaram a identificação de genes envolvidos na utilização de queratina como fonte de nutrientes, e em resposta à presença de agentes citotóxicos em T. rubrum (Maranhão et al. 2007; Paião et al., 2007, Segato et al., 2008). Recentemente, Leal et al. (2007) isolaram transcritos diferencialmente expressos na linhagem mutante $\operatorname{preg}^{\mathrm{c}}$ de $N$. crassa através da utilização da técnica de DDRT-PCR. Análises por microarranjos de cDNA permitiram a identificação de novos genes envolvidos no sistema de aquisição do Pi em S. cerevisiae (Ogawa et al., 2000). Em N. crassa, esta metodologia vem sendo utilizada no estudo dos genes do ciclo circadiano (Correa et al., 2003) e dos mecanismos moleculares envolvidos na esporulação, extensão e ramificação das hifas (Kasuga e Glass, 2008). Desta maneira, estas abordagens vêm sendo extremamente importantes na elucidação de diversos processos celulares, seja em fungos patogênicos ou de interesse biotecnológico, bem como na compreensão dos mecanismos de adaptação ao ambiente. 


\section{OB JETIVOS}

O objetivo geral deste trabalho foi avaliar os mecanismos moleculares envolvidos na resposta adaptativa do fungo filamentoso Neurospora crassa à disponibilidade de Pi.

\section{Objetivos específicos}

- Identificar transcritos diferencialmente expressos na linhagem mutante nuc-2A de $N$. crassa, em condições de Pi-limitante, através da metodologia de biblioteca subtrativa supressiva, e validar os resultados por Northern blot virtual e Northern blot.

- Identificar genes de $N$. crassa regulados pela disponibilidade de Pi extracelular, através de microarranjos de oligonucleotídeos.

- $\quad$ Avaliar o papel funcional do gene mak-2, um dos transcritos regulados por nuc-2, no sensoriamento do Pi extracelular através de microarranjos de oligonucleotídeos. 


\section{MATERIAL E MÉTODOS}




\section{MATERIAL E MÉTODOS}

\subsection{Linhagens de Neurospora crassa}

Foram utilizadas as linhagens St.L.74A (\#2489), nuc-2A (\#1996) e mak-2 (\#11482) de N. crassa, obtidas do Fungal Genetics Stock Center (FGSC), School of Biological Sciences. University of Missouri, EUA.

\subsection{Manutenção e estoque das linhagens}

Para repiques periódicos, frascos de Erlenmeyers contendo $30 \mathrm{ml}$ de meio sólido de Vogel (1956) inclinado foram inoculados com uma pequena porção de hifas e esporos das linhagens selvagem ou mutantes de $N$. crassa. Após inoculação, as culturas foram mantidas em estufa a $30^{\circ} \mathrm{C}$ por 72 horas e posteriormente foram deixadas à temperatura e luz ambiente por 5 dias para favorecer a formação de conídios. As culturas assim obtidas podem ser estocadas por até 30 dias a $4^{\circ} \mathrm{C}$, sendo renovadas após esse período.

Para armazenamento por longos períodos, os conídios foram misturados em leite em pó diluído a $5 \%(\mathrm{~m} / \mathrm{v})$ e transferidos para tubos de $1,5 \mathrm{ml}$ contendo sílica gel seca e esterilizada. Quando necessário, alguns grânulos de sílica eram semeados em meio sólido de Vogel e incubados para o crescimento das linhagens, evitando-se assim repiques sucessivos. 
Meio mínimo sólido de Vogel (Vogel, 1956).

Sais de Vogel 50X

$2 \mathrm{ml}$

Sacarose $(44 \mathrm{mM})$

$1,5 \mathrm{~g}$

Biotina

$143 \mu 1$

Elementos traço

$143 \mu 1$

Agar

$1,5 \mathrm{~g}$

Água destilada (q.s.p.)

$100 \mathrm{ml}$

$\mathrm{O}$ pH do meio foi ajustado para 5,4 e o meio autoclavado a 1 atmosfera de pressão por 20 minutos.

Sais de Vogel 50X (Vogel, 1956).

Citrato de sódio pentahidratado

$15 \mathrm{~g}$

Fosfato de potássio monobásico

$5 \mathrm{~g}$

Nitrato de amônio

$10 \mathrm{~g}$

Sulfato de magnésio heptahidratado

$1 \mathrm{~g}$

Cloreto de cálcio dihidratado

$0,5 \mathrm{~g}$

Água destilada (q.s.p.)

$100 \mathrm{ml}$

Foi adicionado de 2 a $3 \mathrm{ml}$ de clorofórmio como agente antimicrobiano e estocado a $4^{\circ} \mathrm{C}$.

\section{Solução de elementos traço.}

Ácido cítrico monohidratado

$$
\begin{aligned}
& 5 \mathrm{~g} \\
& 5 \mathrm{~g} \\
& 1 \mathrm{~g} \\
& 0,25 \mathrm{~g} \\
& 0,05 \mathrm{~g} \\
& 0,05 \mathrm{~g} \\
& 0,05 \mathrm{~g} \\
& 100 \mathrm{ml}
\end{aligned}
$$$$
\mathrm{ZnSO}_{4} \cdot \mathrm{H}_{2} \mathrm{O}
$$$$
\mathrm{Fe}\left(\mathrm{NH}_{4}\right) 2\left(\mathrm{SO}_{4}\right)_{6} \cdot 6 \mathrm{H}_{2} \mathrm{O}
$$$$
\mathrm{CuSO}_{4} \cdot \mathrm{H}_{2} \mathrm{O}
$$$$
\mathrm{MnSO}_{4} \cdot \mathrm{H}_{2} \mathrm{O}
$$$$
\mathrm{H}_{3} \mathrm{BO}_{3}
$$

$\mathrm{NaMoO}_{4} \cdot \mathrm{H}_{2} \mathrm{O}$

Água destilada (q.s.p.)

Foi adicionado de 2 a $3 \mathrm{ml}$ de clorofórmio como agente antimicrobiano e estocado a $4^{\circ} \mathrm{C}$. 


\subsection{Construção das bibliotecas de subtração de cDNAs (SSH)}

Com o intuito de estudar o papel regulatório do produto do gene nuc-2 em resposta a limitação de Pi exógeno foram construídas duas bibliotecas através de hibridação subtrativa de populações de cDNA seguida de amplificação por PCR dos genes diferencialmente expressos (PCR supressivo), utilizando-se o kit PCR-Select cDNA Subtraction da BD Biosciences Clontech.

\subsubsection{Condições de cultivo para os experimentos de expressão gênica}

Os conídios das linhagens selvagem St.L.74A (\#2489) e mutante nuc-2A (\#1996), cultivadas em meio sólido de Vogel, foram coletados em $15 \mathrm{ml}$ água destilada esterilizada. Para remoção do micélio, essa suspensão foi filtrada em lã de vidro esterilizada e o número de conídios estimado pela contagem em câmara de Neubauer ao microscópio. A suspensão de conídios foi inoculada em meio líquido de Fries (Crocken e Nick, 1963), numa concentração final de $10^{6}$ conídios/ml de meio. As linhagens foram cultivadas a $30^{\circ} \mathrm{C} \mathrm{sob}$ agitação por 5 horas nas condições de baixo Pi $(10 \mu \mathrm{M})$ e pH 5,4. Após esse período, os micélios das linhagens selvagem e mutante foram colhidos por filtração, lavados com água tratada com dietil pirocarbonato (DEPC) (Sambrook et al., 1989), prensados entre folhas de papel filtro para remover o excesso de água, congelados em nitrogênio líquido e armazenados $\mathrm{a}-80^{\circ} \mathrm{C}$ até extração de RNA total. 
Meio líquido de Fries (Crocken e Nick, 1963).

Solução Fries 10X

$10 \mathrm{ml}$

Sacarose

$1,5 \mathrm{~g}$

Solução de biotina

$20 \mu 1$

Solução de elementos traços

$10 \mu 1$

Fosfato de Potássio

$10 \mu \mathrm{M}$

Citrato de Sódio

$50 \mathrm{mM}$

Cloreto de Potássio

$10 \mathrm{mM}$

Água destilada (q.s.p.)

$100 \mathrm{ml}$

$\mathrm{O}$ pH do meio foi ajustado para 5,4 e o meio autoclavado a 1 atmosfera de pressão por 20 minutos.

\section{Solução Fries 10X.}

Nitrato de amônio

$1 \mathrm{~g}$

Sulfato de magnésio heptahidratado

$0,5 \mathrm{~g}$

Cloreto de cálcio dihidratado

$0,1 \mathrm{~g}$

Hidróxido de potássio

$0,4 \mathrm{~g}$

Água destilada (q.s.p.)

$1.000 \mathrm{ml}$

\section{Solução de estoque de biotina.}

Biotina

$5 \mathrm{mg}$

Etanol 50\% (v/v)

$100 \mathrm{ml}$

As soluções foram estocadas a $4^{\circ} \mathrm{C}$, sendo renovas a cada 6 meses. 


\subsubsection{Extração de RNA total}

O RNA total foi extraído utilizando o kit illustra RNAspin mini (GE Healthcare). Aproximadamente $100 \mathrm{mg}$ de micélio foram macerados em um almofariz esterilizado com auxílio de nitrogênio líquido. Após maceração completa, as amostras foram transferidas para tubos de 1,5 ml, acrescentando-se $350 \mu 1$ de tampão RA1 (GE Healthcare) e 3,5 $\mu \mathrm{L} \beta$ mercaptoetanol, misturando vigorosamente. O lisado foi filtrado no NucleoSpin Filter por centrifugação. Posteriormente, a amostra foi transferida para um novo tubo, ao qual adicionaram-se $350 \mu \mathrm{l}$ de etanol 70\%. Em seguida, o filtrado foi transferido para outra coluna (com membrana de sílica) e centrifugado por 30 segundos a 8.000 x $\mathrm{g}$, para promover a ligação do RNA à mesma. A seguir, aplicou-se $350 \mu 1$ de tampão MDB (GE Healthcare) à coluna, seguida da aplicação de $90 \mu \mathrm{L}$ de DNAse. A reação foi mantida à temperatura ambiente por 15 minutos, interrompida com a adição de $200 \mu$ de tampão RA2 (GE Healthcare) e centrifugada por 1 minuto a $10.000 \times \mathrm{g}$. A coluna foi lavada por duas vezes consecutivas com $600 \mu \mathrm{l}$ e $250 \mu \mathrm{l}$ de tampão RA3 (GE Healthcare), respectivamente. Para eluir o RNA preso à coluna, adicionaram-se $50 \mu 1$ de água livre de RNAse e centrifugou-se as amostras por 1 minuto a $10.000 \times \mathrm{g}$.

A concentração do RNA foi determinada por espectrofotometria, pela absorbância das preparações a $260 \mathrm{~nm}$, utilizando $1 \mathrm{DO}_{260}=40 \mu \mathrm{g} / \mathrm{ml}$ de RNA como valor padrão. O grau de pureza foi estimado pela relação DO 260/280 nm, que deve ser próxima a 2 para ácidos nucléicos. Para avaliar a integridade do RNA extraído, todas as amostras foram analisadas através de eletroforese em gel de agarose sob condições desnaturantes. (Sambrook et al., 1989). As amostras foram mantidas a $-80^{\circ} \mathrm{C}$ até a construção das bibliotecas de cDNA. 
Gel para RNA (Sambrook et al., 1989).

Formaldeído

$10 \mathrm{ml}$

Agarose $1,5 \%(\mathrm{~m} / \mathrm{v})$ fundida

$1,5 \mathrm{~g}$

Tampão MOPS 5X

$20 \mathrm{ml}$

Água tratada com DEPC (q.s.p.) $100 \mathrm{ml}$

\section{Tampão de migração (MOPS 5X).}

MOPS pH 7,0

$0,1 \mathrm{M}$

Acetato de sódio

$40 \mathrm{mM}$

EDTA pH 8,0

$5 \mathrm{mM}$

Este tampão foi preparado com água livre de RNAse e mantido em frasco escuro à temperatura ambiente.

\section{Preparo das amostras de RNA.}

Em um microtubo de 1,5 ml foram misturados $3 \mu 1$ de RNA, $2 \mu 1$ de tampão de corrida $5 \mathrm{X}, 3,5 \mu \mathrm{l}$ de formaldeído, $10 \mu \mathrm{l}$ de formamida e $2 \mu \mathrm{l}$ de tampão de carregamento [tampão de corrida 1X, glicerol 30\% (v/v) e azul de bromofenol contendo brometo de etídeo $(1 \mu \mathrm{g} / \mu \mathrm{l})]$. As amostras foram incubadas a $65^{\circ} \mathrm{C}$ por 15 minutos e resfriadas rapidamente em gelo. A seguir, foram aplicadas em gel desnaturante e submetidas à eletroforese por $4 \mathrm{~V} / \mathrm{cm}$ em tampão de corrida $1 \mathrm{X}$.

\section{Água livre de RNAse (Sambrook et al., 1989).}

Para evitar a contaminação com RNAse, a água deionizada utilizada no preparo de soluções para RNA foi tratada com DEPC a $0,1 \%$ (v/v) e incubada a $37^{\circ} \mathrm{C}$ por $18-20$ horas. Após esse tempo, foi autoclavada por 30 minutos a 1 atmosfera de pressão. 


\subsubsection{Síntese de cDNAs}

Os RNAs extraídos das linhagens St.L.74A e nuc-2A de $N$. crassa cultivadas sob condições de Pi-limitante $(10 \mu \mathrm{M})$ e pH 5,4 foram usados para síntese de cDNAs, utilizando-se o SMART PCR cDNA Synthesis kit (BD Biosciences Clontech), conforme instruções do fabricante.

O kit SMART PCR cDNA Synthesis faz uso da atividade transferase terminal da enzima Transcriptase Reversa (RT) para ancorar iniciadores na porção $5^{\prime}$ terminal de todos os cDNAs sintetizados. Esta atividade faz com que, ao chegar à porção $5^{\prime}$ final do mRNA, a enzima catalise a adição de uma pequena repetição de citosinas na fita de cDNA sintetizada. Isto se deve ao fato do kit conter um iniciador que, por possuir uma região rica em guaninas, se pareia ao poli-C adicionado que passa a servir como molde para a RT. Desta forma, uma região do iniciador é adicionada ao cDNA. A seguir, usando-se um iniciador para esta região e para a porção de poli-A do RNA mensageiro, os cDNAs completos sintetizados são amplificados por Long Distance PCR (LD-PCR), na fase exponencial de reação. Os cDNAs incompletos, os RNAs ribossômicos e o DNA genômico não são amplificados, pois não possuem sítios de pareamento para estes iniciadores, garantindo um cDNA completo de alta qualidade.

Para a reação de síntese de cDNAs de cada amostra foram combinados em um único tubo os seguintes reagentes:

$\begin{array}{ll}\text { RNA total }(1 \mu \mathrm{g}) & 1-3 \mu \mathrm{l} \\ \text { 3'BD Smart CDS Primer IIA }(12 \mu \mathrm{M}) & 1 \mu \mathrm{l} \\ \text { BD Smart IIA oligonucleotide }(12 \mu \mathrm{M}) & 1 \mu \mathrm{l} \\ \text { Água deionizada esterilizada (q.s.p.) } & 5 \mu \mathrm{l}\end{array}$


As amostras foram incubadas a $72^{\circ} \mathrm{C}$ por 2 minutos, esfriadas em gelo e centrifugadas brevemente. A seguir adicionou-se a cada amostra os seguintes reagentes:

$\begin{array}{ll}\text { 5X First-Strand Buffer } & 2 \mu \mathrm{l} \\ \text { DTT (20 mM) } & 1 \mu \mathrm{l} \\ \text { 50X dNTPs (10 mM de cada) } & 1 \mu \mathrm{l} \\ \text { BD PowerScript reverse transcriptase } & 1 \mu \mathrm{l}\end{array}$

As reações foram incubadas a $42^{\circ} \mathrm{C}$ por 1 hora, colocadas em gelo e diluídas com $40 \mu 1$ de TE (10mM Tris-HCl; 1mM EDTA pH 8,0).

Após a síntese e diluição dos cDNAs procedeu-se ao LD-PCR, para o qual foi preparada a seguinte mistura de reação:

$\begin{array}{ll}\text { 10X BD advantage 2 PCR } & 10 \mu \mathrm{l} \\ \text { 50X dNTPs (10 mM de cada) } & 2 \mu \mathrm{l} \\ \text { 5' PCR Primer IIA (12 } \mu \mathrm{M}) & 2 \mu \mathrm{l} \\ \text { 50X BD advantage 2 Polymerase Mix } & 2 \mu \mathrm{l} \\ \text { Água deionizada } & 74 \mu \mathrm{l}\end{array}$

A seguir foram incorporados os cDNAs previamente diluídos (1:10). Os parâmetros de amplificação foram: $95^{\circ} \mathrm{C}$ por 1 minuto, seguido de ciclos de 15 segundos a $95^{\circ} \mathrm{C}, 65^{\circ} \mathrm{C}$ por 30 segundos e $68^{\circ} \mathrm{C}$ por 6 minutos. O número de ciclos de amplificação foi otimizado para cada uma das amostras com o objetivo de obter cDNA fita dupla sem que a PCR atingisse o platô, pois a manutenção da heterogeneidade quantitativa dos genes expressos nas amostras deve ser mantida, a fim de que não se perca as diferenças quantitativas entre as moléculas de cDNA nas diferentes condições experimentais. Para isso, foram montadas 2 reações de PCR por amostra, sendo que uma reação foi usada no processo de otimização 
e outra foi utilizada para gerar o cDNA necessário para posterior construção da SSH. Após 15 ciclos, um tubo de cada amostra foi guardado a $4^{\circ} \mathrm{C}$ e um único tubo foi utilizado para determinar o número ótimo de ciclos. Alíquotas de $5 \mu \mathrm{l}$ do produto da amplificação retiradas nos ciclos 15, 18, 21, 24 e 27 foram submetidas à eletroforese em gel de agarose 1,2\% para determinação do número ideal de ciclos requerido para cada amostra experimental.

\subsubsection{Purificação dos cDNAs dupla fita}

Após o LD-PCR, as amostras foram purificadas na coluna BD CHROMA SPIN 1000. Para isso, em cada amostra foi adicionado igual volume de fenol:clorofórmio:álcool isoamílico (25:24:1), a mistura foi homogeneizada vigorosamente e centrifugada a 10.000 x $g$ por 10 minutos. Posteriormente, a fase superior foi removida e transferida para um novo tubo contendo $700 \mu \mathrm{l}$ de n-butanol; misturada por inversão e centrifugada por 1 minuto a $10.000 \times \mathrm{g}$. Por último, a fase aquosa orgânica (fase superior, n-butanol) foi descartada, e a fase inferior aplicada à coluna BD CHROMA SPIN 1000.

As amostras de cDNA purificadas foram quantificadas determinando-se a absorbância a $260 \mathrm{~nm}$ considerando-se como valor padrão $1 \mathrm{DO}_{260}=50 \mu \mathrm{g} / \mathrm{ml}$ de cDNA. Os cDNAs purificados foram analisados por eletroforese em gel de agarose $1,2 \%$.

\subsubsection{Digestão com RsaI}

Os cDNAs purificados foram digeridos com a enzima RsaI com o objetivo de reduzir a complexidade dos fragmentos e gerar o sítio para ligar posteriormente os adaptadores (1 e 2R). A digestão foi realizada usando: 
cDNA fita dupla

Tampão da enzima (10X)

Albumina sérica bovina acetilada $(10 \mu \mathrm{g} / \mu \mathrm{l})$

Rsa I (10U/ $\mu \mathrm{l})$

Água deionizada esterilizada (q.s.p.)
$350 \mu 1$

$40 \mu 1$

$4 \mu 1$

$2 \mu 1$

$400 \mu 1$

A reação foi incubada a $37^{\circ} \mathrm{C}$ por 3 horas. Posteriormente, $5 \mu$ da reação foram separados para a análise da eficiência da digestão em gel de agarose $1,5 \%(\mathrm{~m} / \mathrm{v})$. Ao restante da reação foram adicionados $2,5 \mu \mathrm{l}$ de EDTA/Glicogênio 20X. As amostras digeridas foram purificadas e secas em SpeedVac por 20 minutos a $37^{\circ} \mathrm{C}$; e o precipitado ressuspendido em $7 \mu$ de água deionizada esterilizada.

\subsubsection{Ligação dos adaptadores}

A ligação dos adaptadores ao cDNA da condição teste é um passo essencial para o funcionamento adequado da subtração. As amostras de cDNA teste foram divididas em duas porções, sendo cada uma ligada a um adaptador diferente (1 ou 2R). Cada um dos adaptadores tem distintos iniciadores, e uma única extremidade fosforilada, a fim de permitir a ligação direcional aos fragmentos de cDNA. Para a ligação dos adaptadores foram preparadas a seguintes misturas de reação.

$\begin{array}{lll}\text { Reagentes } & \text { Tubo 1 (adaptador 1) } & \text { Tubo 2 (adaptador 2R) } \\ \text { cDNA teste diluído (1:5) } & 2 \mu \mathrm{l} & 2 \mu \mathrm{l} \\ \text { Tampão de ligação } & 2 \mu \mathrm{l} & 2 \mu \mathrm{l} \\ \text { Adaptador 1 } & 2 \mu \mathrm{l} & - \\ \text { Adaptador 2R } & - & 2 \mu \mathrm{l} \\ \text { T4 DNA ligase } & 1 \mu \mathrm{l} & 1 \mu \mathrm{l} \\ \text { Água deionizada } & 3 \mu \mathrm{l} & 3 \mu \mathrm{l} \\ \text { Volume final } & 6 \mu \mathrm{l} & 6 \mu \mathrm{l}\end{array}$


Os tubos foram incubados a $16^{\circ} \mathrm{C}$ por 18 horas. A ligação foi interrompida com $1 \mu 1$ de EDTA/Glicogênio 20X, e a DNA ligase foi inativada por aquecimento a $72^{\circ} \mathrm{C}$ por 5 minutos.

\subsubsection{Primeira e segunda hibridação}

A hibridação subtrativa foi realizada em duas etapas. Na primeira hibridação os cDNAs foram desnaturados a $95^{\circ} \mathrm{C}$, adicionando-se o cDNA da condição controle em excesso a cada uma das amostras de cDNA da condição teste ligadas a um dos adaptadores. A temperatura foi então reduzida a $68^{\circ} \mathrm{C}$ e as amostras hibridadas durante 8 horas, ocorrendo uma renaturação parcial. Devido à cinética de hibridação ser de segunda ordem, as moléculas abundantes sofrem reanelamento mais rápido, ocorrendo uma equalização entre as moléculas de fita simples. Ao mesmo tempo, as moléculas de fita simples com expressão diferencial são enriquecidas em relação às não diferencialmente expressas, as quais tendem a formar híbridos com o cDNA da condição controle, pelo fato deste estar super representado.

\section{Reagentes}

cDNA controle

cDNA teste ligado ao adaptador 1

cDNA teste ligado ao adaptador $2 \mathrm{R}$

Tampão de hibridação 4X

Volume final

\section{Hibridização 1 Hibridização 2}

$1,5 \mu \mathrm{l}$

$1,5 \mu 1$

$1,5 \mu 1$

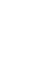

$1,5 \mu 1$

$1 \mu l$

$1 \mu l$

$4 \mu l$

$4 \mu l$

A segunda hibridação subtrativa foi realizada misturando as duas amostras da primeira hibridação com a adição de mais cDNA da condição controle desnaturado, incubando a $68^{\circ} \mathrm{C}$ por 18 horas. Decorrido o tempo de incubação, foram acrescentados 200 $\mu l$ de tampão de diluição, e as amostras foram mantidas por mais 7 minutos a $68^{\circ} \mathrm{C}$ e 
estocadas a $-20^{\circ} \mathrm{C}$ até o momento do uso. Durante essa etapa, somente as moléculas fita simples equalizadas e diferencialmente expressas devem reassociar-se, formando híbridos com adaptadores terminais diferentes (provenientes das duas amostras de cDNA da condição teste).

\subsubsection{Amplificação por PCR}

A amplificação dos fragmentos diferencialmente expressos foi realizada por PCRNested. No PCR primário foi utilizado o PCR Primer 1 para amplificação dos cDNAs. A região mais externa dos adaptadores 1 e $2 \mathrm{R}$ possuem seqüências idênticas que permitem $\mathrm{o}$ pareamento do PCR primer 1, após o preenchimento das extremidades dos fragmentos de cDNA. As moléculas contendo o mesmo adaptador nas duas pontas não são amplificadas adequadamente pois, devido à sua complementariedade, ocorre uma tendência destas pontas parearem entre si (efeito supressivo). No PCR secundário, utilizou-se uma alíquota diluída do PCR primário (3:100) e iniciadores com sítios de pareamento na região mais interna dos adaptadores.

O PCR primário foi incubado por 5 minutos a $75^{\circ} \mathrm{C}$ para extensão dos adaptadores, seguidos de 35 ciclos de 30 segundos a $94^{\circ} \mathrm{C}, 30$ segundos a $66^{\circ} \mathrm{C}$ e 1 minuto a $72^{\circ} \mathrm{C}$, e uma extensão final de 10 minutos a $72^{\circ} \mathrm{C}$. Para o PCR secundário, foram utilizadas as mesmas condições de amplificação, variando a temperatura de pareamento de $66^{\circ} \mathrm{C}$ para $68^{\circ} \mathrm{C}$ e o número de ciclos de amplificação de 35 para 18. Para a visualização do produto do PCRNested (bandas correspondentes a genes diferencialmente expressos), as amostras foram aplicadas em gel de agarose $2 \%$ e submetidas à eletroforese. Os fragmentos resultantes foram recortados em faixas de massa molecular (400-600 pb; 600-800 pb; 800-1.000 pb). Em seguida, os cDNAs foram purificados em colunas GFX PCR DNA and Gel Band 
Purification (GE Healthcare) e eluídos em $50 \mu 1$ de água esterilizada. Estas colunas são feitas de matriz de fibra de vidro, às quais o DNA se liga na presença de agentes caotrópicos, permitindo sua purificação com remoção de proteínas, nucleotídeos, sais e fragmentos pequenos de DNA, tais como iniciadores.

\subsubsection{Clonagem dos fragmentos de cDNAs obtidos nas bibliotecas de subtração}

Os cDNAs resultantes da purificação foram ligados em vetor pGEM-T Easy Vector

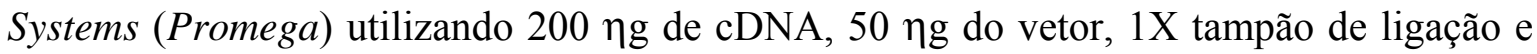
5U da T4 DNA ligase. As ligações foram realizadas em um volume final de $10 \mu \mathrm{l}$ e incubadas por 18 horas a $16^{\circ} \mathrm{C}$. Em seguida, os plasmídios recombinantes foram utilizados para transformar células competentes de Escherichia coli por heat shock. O protocolo para obtenção de células competentes é descrito a seguir:

\section{Preparo de células competentes.}

A cepa de E. coli MOS Blue foi inoculada em $5 \mathrm{ml}$ de meio LB líquido contendo tetraciclina (15 $\mu \mathrm{g} / \mathrm{ml})$, a partir de uma célula que foi previamente estriada do estoque, e cultivada por 18 horas a $37^{\circ} \mathrm{C}$. Uma alíquota de $3 \mathrm{ml}$ desta cultura foi inoculada em $250 \mathrm{ml}$ de meio LB com tetraciclina e cultivada por mais $2-3$ horas, a $37^{\circ} \mathrm{C}$ até a obtenção de uma $\mathrm{DO}_{600}$ de $0,5-0,6$. A cultura foi então colocada em banho de gelo por 30 minutos e recolhida por centrifugação $\left(4.000 \times \mathrm{g}\right.$ por 10 minutos a $\left.4^{\circ} \mathrm{C}\right)$. A seguir, as células foram ressuspendidas em $125 \mathrm{ml}$ de tampão I (10 mM Tris- $\mathrm{HCl} ; 50 \mathrm{mM} \mathrm{CaCl} 2 \mathrm{pH} 7,5)$, incubadas em gelo por 15 minutos e centrifugadas $\left(4.000 \times \mathrm{g}\right.$ por 10 minutos a $\left.4^{\circ} \mathrm{C}\right) . \mathrm{O}$ precipitado foi ressuspendido em 3,5 ml de tampão II (10 mM Tris- $\mathrm{HCl} ; 50 \mathrm{mM} \mathrm{CaCl} 2$; $15 \%$ glicerol $\mathrm{pH} 7,5)$ e dividido em alíquotas de $200 \mu \mathrm{l}$. Por último, as células 
competentes, foram congeladas em nitrogênio líquido e estocadas a $-80^{\circ} \mathrm{C}$ até utilização. Os tampões e materiais utilizados na preparação foram mantidos a $4{ }^{\circ} \mathrm{C}$.

\section{Transformação por heat shock.}

Os plasmídios recombinantes foram utilizados para transformar a cepa pMOS Blue de E. coli (endA1 hsdR17 supE44 recA1 gyrA96 relA1 lac [F', pro $\mathrm{AB}$, lac 1, Z $\Delta \mathrm{M} 15$, Tn10 (Tetr)]). Uma alíquota de $200 \mu 1$ de células competentes foi descongelada em banho de gelo e recebeu a adição de DNA transformante (10-50 ๆg). Após 30 minutos em gelo, as bactérias foram colocadas por 40 segundos a $42^{\circ} \mathrm{C}$ e transferidas para o gelo por 2 minutos. A seguir, foram resuspendidas em $800 \mu \mathrm{l}$ de meio Luria Bertani (LB) sem antibiótico e incubadas por 1 hora a $37^{\circ} \mathrm{C}$ sob agitação. Finalmente, as bactérias foram plaqueadas em LB-agar contendo $50 \mu \mathrm{g} / \mathrm{ml}$ de ampicilina, $50 \mathrm{mg} / \mathrm{ml}$ de X-gal e $0,2 \mathrm{mg} / \mathrm{mL}$ de IPTG e cultivadas por 18 horas a $37^{\circ} \mathrm{C}$.

As colônias bacterianas brancas (transformadas) foram selecionadas e incubadas em meio LB contendo $50 \mu \mathrm{g} / \mathrm{ml}$ de ampicilina por 18 horas a $37^{\circ} \mathrm{C}$ sob agitação, em microplacas de 96 poços. Uma alíquota destas bactérias foi congelada a $-80^{\circ} \mathrm{C}$, em glicerol $70 \%$. 
Meio de Luria Bertani - LB (Sambrook et al., 1989).

Triptona $10 \mathrm{~g}$

Extrato de levedura $5 \mathrm{~g}$

Cloreto de potássio $0,2 \mathrm{~g}$

Cloreto de sódio $0,6 \mathrm{~g}$

Água destilada (q.s.p.) $1.000 \mathrm{ml}$

$\mathrm{O}$ pH do meio foi ajustado em 7,4 e autoclavado. Quando necessário, adicionou-se ágar $(1,5 \%)$ ao meio antes da autoclavagem.

Solução de X-Gal (5-Bromo-4-Cloro-3-Indolil-B-D-galactosideo) (Sambrook et al., 1989).

A solução estoque de X-gal foi preparada dissolvendo $20 \mathrm{mg}$ deste composto em $1 \mathrm{~mL}$ de N,N'-dimetilformamida. Esta solução foi divida em alíquotas que foram estocadas a $-20^{\circ} \mathrm{C}$ ao abrigo da luz para prevenir fotodegradação.

\section{Solução de IPTG (Isopropil- $\beta$-D-l- tiogalactopiranosídeo) (Sambrook et al., 1989).}

A solução estoque de IPTG foi preparada dissolvendo $2 \mathrm{~g}$ de IPTG em $10 \mathrm{ml}$ de água destilada. Esta solução foi esterilizada por filtração através de um filtro esterilizado de $25 \mu \mathrm{m}$ (Corning). A solução foi dividida em alíquotas e mantida a $-20^{\circ} \mathrm{C}$. 


\subsubsection{Rastreamento dos cDNAs diferencialmente expressos por Northern blot reverso (Dilks et al., 2003)}

Esta metodologia foi utilizada para rastrear as ESTs (Expressed Sequence Tags) diferencialmente expressas por $N$. crassa. Os clones provenientes das duas $\mathrm{SSH}$ foram amplificados por PCR utilizando oligonucleotídeos que se pareiam aos adaptadores 1 e $2 \mathrm{R}$. Os produtos de PCR foram arranjados em membranas de náilon, em duplicatas, e hibridados, separadamente, contra populações de cDNA provenientes das duas condições a serem comparadas: teste e controle de cada biblioteca. Os clones que tiveram sinal de hibridação mais intenso quando o cDNA da condição teste foi usada como sonda, em relação ao controle, foram selecionados para seqüenciamento.

\section{Amplificação por PCR.}

Amostras de $2 \mu \mathrm{l}$ dos clones bacterianos contendo fragmentos de cDNA, crescidos em microplacas de 96 poços, foram amplificados por PCR usando 1X tampão Taq, 1,5 mM de $\mathrm{MgCl}_{2}, 200 \mu \mathrm{M}$ de dNTP, 0,2 $\mu \mathrm{M}$ de cada primer 1 e $2 \mathrm{R}(10 \mu \mathrm{M})$ e $1 \mathrm{U}$ de Taq DNA polimerase. $\mathrm{O}$ volume final foi completado para $20 \mu \mathrm{l}$ com água deionizada esterilizada. A reação foi submetida durante 2 minutos a $95^{\circ} \mathrm{C}$ para lise inicial das bactérias, seguido de 32 ciclos de 30 segundos a $95^{\circ} \mathrm{C}, 68^{\circ} \mathrm{C}$ por 45 segundos, $72^{\circ} \mathrm{C}$ por um minuto, e uma extensão final a $72^{\circ} \mathrm{C}$ por 10 minutos. $\mathrm{O}$ produto da reação foi fracionado em gel de agarose $1,2 \%$, em tampão TAE 1X (40 mM Tris base; 1\% ácido acético; 1 mM EDTA, pH 8,0). 


\section{Construção de macroarranjos de cDNA.}

Aproximadamente $500 \eta \mathrm{g}$ (4 $\mu 1$ do produto de PCR) foram denaturados acrescentando-se $4 \mu \mathrm{L}$ de $\mathrm{NaOH}$ 0,6N. A seguir, o cDNA amplificado foi diluído com 100 $\mu \mathrm{L}$ de tampão TE e aplicado sobre membranas de náilon $\mathrm{N}-\mathrm{Hybond}^{+}$(GE Healthcare) utilizando sistema de transferência a vácuo. As membranas foram incubadas a $80^{\circ} \mathrm{C}$ por 15 minutos, e expostas à luz UV por 2 minutos para a fixação do cDNA.

\section{Marcação da sonda de cDNA.}

O kit Gene Images Random Prime Labelling Module (GE Healthcare) foi utilizado para a marcação da sonda de cDNA. O produto do PCR Nested da biblioteca de subtração de cDNA, foi diluído para $200 \eta \mathrm{g}$, denaturado por 5 minutos a $95^{\circ} \mathrm{C}$ e colocado em gelo. Em um tubo de $1,5 \mathrm{ml}$ previamente gelado, foram adicionados os seguintes reagentes, mantendo a ordem a seguir: água deionizada esterilizada para um volume final de $50 \mu l, 10 \mu 1$ de

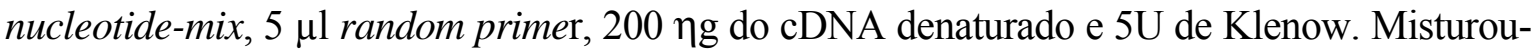
se suavemente e incubou-se a reação por 1 hora a $37^{\circ} \mathrm{C}$. A reação foi interrompida pela adição de $20 \mathrm{mM}$ de EDTA e mantida a $-20^{\circ} \mathrm{C}$ no escuro até o momento do uso.

\section{Hibridação e lavagem das membranas.}

As membranas foram préhibridadas em solução de hibridação (5X SSC, 0,1\% SDS, $5 \%$ dextran sulfato, líquido bloqueador diluído 20 vezes) a $60^{\circ} \mathrm{C}$ por 2-3 horas. A seguir, a sonda marcada e previamente denaturada foi adicionada e a hibridação foi realizada a $60^{\circ} \mathrm{C}$ por 18 horas. Após este período, seguiram-se duas lavagens por 15 minutos a $60^{\circ} \mathrm{C}$, a primeira com uma solução de 1 X SSC e $0,1 \%$ SDS e a segunda com uma solução de 0,5 X SSC e $0,1 \%$ SDS. A seguir, incubou-se as membranas com uma solução de líquido 
bloqueador e tampão $\mathrm{A}(100 \mathrm{mM}$ Tris- $\mathrm{HCl} \mathrm{pH} 9,5 ; 300 \mathrm{mM} \mathrm{NaCl})(1: 10)$ durante 1 hora à temperatura ambiente. Para detecção da marcação foi utilizado o kit Gene Image CDP-Star Detection Module (GE Healthcare). O anticorpo anti-fluoresceína conjugado com fosfatase alcalina (anti-fluorescein alkaline phosphatase (AP) conjugate) foi diluído em tampão A contendo BSA $0,5 \%(\mathrm{~m} / \mathrm{v})$. As membranas foram incubadas neste tampão por 2-3 horas à temperatura ambiente, e posteriormente foram lavadas por três vezes, para remover o excesso de conjugado, com uma solução $0,3 \%$ de tween $20(\mathrm{v} / \mathrm{v})$ preparada com buffer A. O reagente de detecção foi colocado sobre as membranas $\left(30-40 \mu 1 / \mathrm{cm}^{2}\right)$ e as mesmas foram expostas a um filme auto-radiográfico por cerca de 1 hora à temperatura ambiente.

\subsubsection{Seqüenciamento das ESTs diferencialmente expressas}

\section{Extração de DNA plasmidial em microplaca.}

O DNA plasmidial dos clones de interesse obtidos a partir da SSH (após rastreamento por Northern blot reverso) foi extraído para a realização do seqüenciamento dos genes diferencialmente expressos por N. crassa.

Para isso, os clones selecionados foram inoculados em $1 \mathrm{~mL}$ de LB com ampicilina $(50 \mu \mathrm{g} / \mathrm{ml})$ e tetraciclina $(15 \mathrm{mg} / \mathrm{ml})$ em microplaca contendo 96 poços e cultivados a $37^{\circ} \mathrm{C}$ por 22 horas sob vigorosa agitação. Após o crescimento, a microplaca foi centrifugada a $2.500 \times \mathrm{g}$ por 6 minutos. O sobrenadante foi descartado e $240 \mu \mathrm{l}$ de solução I (50mM glicose; 25mM Tris-HCl; 10mM EDTA $\mathrm{pH} 8,0$ ) foram adicionados em cada poço. A microplaca foi submetida à agitação vigorosa por 5 minutos e novamente centrifugada a $2.500 \mathrm{x} g$ por 6 minutos. O sobrenadante foi descartado e $85 \mu 1$ de uma mistura contendo 17,6 $\mathrm{ml}$ de solução I e 1,1 ml de RNAse $(10 \mathrm{mg} / \mathrm{ml})$ foram adicionados em cada poço. 
Após 10 minutos de incubação, as suspensões foram transferidas para uma placa tipo ELISA e $60 \mu 1$ de solução II (1\% SDS; 0,2 M NaOH) foram adicionados em cada poço. A placa foi homogeneizada por inversão e mantida à temperatura ambiente por 10 minutos. Após este período, $60 \mu \mathrm{l}$ de acetato de potássio $3 \mathrm{M}$ foram adicionados em cada poço e a placa novamente homogeneizada por inversão e mantida à temperatura ambiente por 10 minutos. Em seguida, a placa foi incubada a $90^{\circ} \mathrm{C}$ por 30 minutos e resfriada em gelo por 5 minutos. As amostras foram transferidas para uma placa Millipore acoplada a uma placa tipo ELISA e este sistema foi centrifugado por 6 minutos a 2.500 x g. O sistema foi desmontado e o DNA plasmidial presente no filtrado foi precipitado com $110 \mu \mathrm{de}$ isopropanol. A placa foi centrifugada por 45 minutos a $2.500 \mathrm{x} \mathrm{g}$, o precipitado foi lavado com etanol $70 \%$ e centrifugado por 10 minutos a $2.500 \times \mathrm{g}$. O DNA plasmidial foi seco a $65^{\circ} \mathrm{C}$ por 15 minutos e ressuspendido em $25 \mu$ de água esterilizada.

\section{Seqüenciamento automatizado de DNA.}

As reações de seqüencimento foram realizadas com o kit ABI Prism Big Dye Terminator Cycle Sequencing, utilizando 200 a $400 \eta \mathrm{g}$ de DNA plasmidial, 5 pmol de oligonucleotídeo M13F e $2 \mu 1$ do reagente Big Dye. As amostras foram denaturadas por 2 minutos a $96^{\circ} \mathrm{C}$, seguidos de 40 ciclos de 30 segundos a $96^{\circ} \mathrm{C}, 30$ segundos a $52^{\circ} \mathrm{C}$ e 4 minutos a $60^{\circ} \mathrm{C}$, e 10 minutos a $72^{\circ} \mathrm{C}$ para extensão final.

Após a ciclagem, as amostras foram precipitadas acrescentando-se $2 \mu \mathrm{l}$ de uma solução contendo 1,5 M acetato de sódio e $250 \mathrm{mM}$ EDTA, e em seguida $80 \mu \mathrm{l}$ de etanol absoluto. As amostras foram incubadas por 20 minutos no escuro à temperatura ambiente e centrifugadas a $2.500 \times \mathrm{g}$ por 45 minutos, a $4^{\circ} \mathrm{C}$. O sobrenadante foi descartado, o precipitado lavado com $150 \mu \mathrm{l}$ etanol $70 \%(\mathrm{v} / \mathrm{v})$ gelado e centrifugado a $2.500 \mathrm{x} g$ por 10 
minutos, a $4^{\circ} \mathrm{C}$. Depois de secas, as amostras foram ressuspendidas com 2,5 $\mu 1$ de loading color, e 0,7 $\mu$ f foram aplicados em gel de poliacrilamida para serem analisadas, e seqüenciadas automaticamente no ABI Prism 377 DNA Sequencer (Perkin Elmer).

\subsubsection{Análise e anotação das ESTs de $N$. crassa}

A análise da qualidade das seqüências das ESTs foi realizada através do programa Phred (Ewing et al., 1998; Ewing e Green, 1998), que atribui um valor de qualidade para cada base. A retirada das seqüências referentes ao vetor de clonagem e aos adaptadores utilizados na construção das SSHs foi realizada através do programa cross-match (Ewing et al., 1998). O agrupamento das seqüências foi realizado através do programa CAP3 (Huang e Madan, 1999), e a anotação das ESTs foi feita utilizando-se os algoritmos BLASTx (Altschul et al., 1997), através da comparação com seqüências depositadas no banco de dados de proteínas do National Center of Biotechnology Information (http://www.ncbi.nlm.nih.gov/blast/), e BLASTn comparando com sequências de $N$. crassa previamente depositadas (Galagan et al., 2003) (http://www.broad.mit.edu/annotation/genome/neurospora/Home.html)

A categorização funcional das ESTs foi feita mediante a base de dados MIPS FunCat (Munich Information Center for Protein; http://mips.gsf.de) (Mewes et al., 1997; Mewes et al., 2002; Ruepp et al., 2006).

\subsubsection{Confirmação dos genes diferencialmente expressos}

Uma vez validado o processo de subtração, através de Northern blot reverso, foi possível selecionar os clones de interesse para confirmar a expressão diferencial destes genes através de ensaios do tipo Northern blot virtual e Northern blot. 


\section{Validação por Northern blot virtual.}

Northern Blot virtual (Franz et al., 1999) foi utilizado como a primeira metodologia para validação de genes. Esta técnica foi desenvolvida pela Clontech (BD SMART ${ }^{\mathrm{TM}} \mathrm{mRNA}$ Amplification Kit) e consiste na produção de cDNA fita simples seguida da amplificação de todo o conjunto de cDNAs presente na amostra, resultando em cDNA fita dupla, a partir de pequenas quantidades de RNA total.

Para cada amostra utilizou-se $1 \mu \mathrm{g}$ de RNA total, $12 \mu \mathrm{M}$ do primer BD CDC II e $12 \mu \mathrm{M}$ do primer BD Smart II A, completando-se o volume para $5 \mu 1$ com água milliQ. Após incubação a $70^{\circ} \mathrm{C}$ por 2 minutos, foram adicionados a cada amostra, tampão da transcriptase a uma concentração final de $1 \mathrm{X}$, DTT 0,5mM, $200 \mu \mathrm{M}$ de cada dNTP e $200 \mathrm{U}$ da transcriptase BD Power Script Reverse Transcriptase. A seguir, os tubos foram incubados a $42^{\circ} \mathrm{C}$ por 1 hora. $\mathrm{O}$ produto da primeira reação foi diluído com TE para um volume final de $40 \mu 1$ e incubado a $72^{\circ} \mathrm{C}$ por 15 minutos. A reação de PCR foi montada acrescentando-se a $1 \mu 1$ de cDNA fita simples (diluído 1:10), tampão BD Advantage 1X, $200 \mu \mathrm{M}$ de cada dNTP, $12 \mu \mathrm{M}$ do 5' PCR Primer II A e BD Advantage 2 Polimerase Mix a $1 \mathrm{X}$, para um volume final de $100 \mu 1$.

O produto da reação foi analisado em gel de agarose $1,2 \%$. O gel foi fotografado e a seguir mergulhado em $\mathrm{HCl} 0,2 \mathrm{~N}$ por 10 minutos, a fim de promover a depurinação. A seguir, o gel foi transferido para solução denaturante, onde foi mantido por 30 minutos, e finalmente incubou-se o gel por duas vezes consecutivas em solução neutralizante, por 15 e 30 minutos, respectivamente. A membrana de náilon $\mathrm{N}-H y b o n d^{+}$(GE Healthcare) foi umedecida em 2X SSC por 5 minutos e o sistema de transferência foi montado. 


\section{Validação por Northern blot.}

Para a realização deste ensaio foi feita uma nova extração de RNA total nas mesmas condições de crescimento utilizadas anteriormente. Esta extração foi necessária devido à degradação do RNA extraído originalmente, mas também para verificar a reprodutibilidade do experimento. Os micélios foram macerados em nitrogênio líquido, sendo o isolamento do RNA total de cada amostra realizado com o reagente Trizol ${ }^{\circledR}$ (Invitrogen) de acordo com as instruções do fabricante.

Os RNAs extraídos foram resolvidos em gel de agarose denaturante com formaldeído até que o corante azul de bromofenol mostrasse uma migração de aproximadamente $8 \mathrm{~cm}$. Foram carregados $15 \mu \mathrm{g}$ de cada RNA por poço, quantificado no GeneQuant $^{\mathrm{TM}}$ pro RNA/DNA calculator (GE Healthcare). O gel contendo os RNAs foi fotografado e em seguida tratado com $\mathrm{NaOH} 50 \mathrm{mM}$ por 20 minutos e $20 \mathrm{X}$ SSC por 45 minutos, e a seguir transferido para membrana de náilon $\mathrm{N}-$ Hybond $^{+}$(GE Healthcare).

A normalização da quantidade de RNA carregado por poço foi realizada por visualização das bandas de RNA ribossomal no gel. A marcação da sonda com radioisótopo $\alpha-\mathrm{CTP}^{32}$ (> 3000 ci, GE Healthcare $)$ foi realizada a partir de hexaoligonucleotídio aleatório e enzima Klenow, a $37^{\circ} \mathrm{C}$ por 2 horas. A sonda foi então purificada para remover os nucleotídeos não incorporados utilizando uma coluna de Sephadex G-50. A pré-hibridação e hibridação foram realizadas a $65^{\circ} \mathrm{C}$, e as lavagens seguiram o protocolo padrão (Sambrook et al., 1989). A aquisição das imagens de hibridação foram realizadas em um leitor de fósforo radioativo (Cyclone Plus Phosphor Imager, Perkin Elmer). 


\subsection{Análise da expressão gênica por microarranjos de oligonucleotídeos}

Com o intuito de estudar o envolvimento do gene mak-2 (MAP quinase 2) no monitoramento do $\mathrm{Pi}$ extracelular, realizamos experimentos de microarranjos de oligonucleotídeos comparando as linhagens selvagem St.L.74A (FGSC\#2489) e mutante mak-2 ${ }^{\mathrm{ko}}$ (FGSC\#11482, com o gene inativado) cultivadas em diferentes níveis de Pi, conforme esquema mostrado na Figura 4.

Os experimentos de microarranjos foram realizados no Laboratório de Genômica e Expressão Gênica em Câncer do Instituto de Química (IQ) da USP, sob a coordenação do Prof. Dr. Eduardo Moraes Rego Reis.

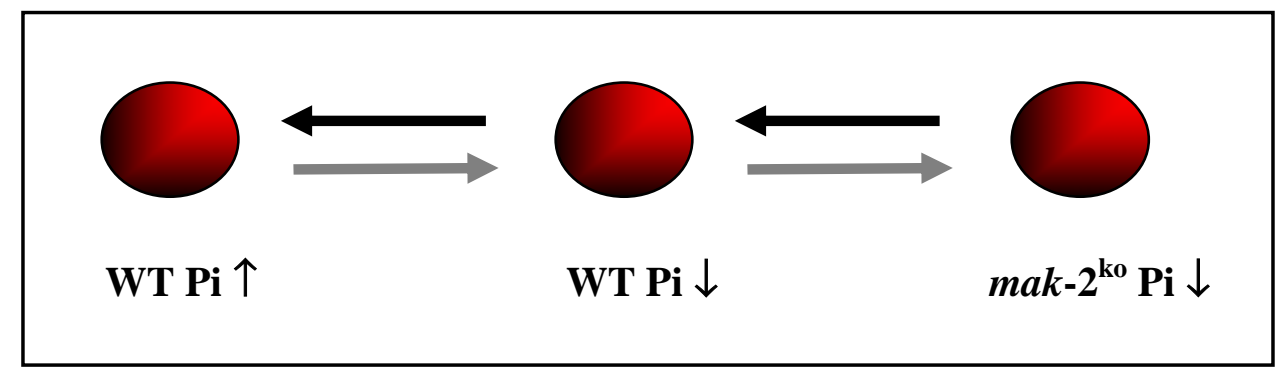

Figura 4. Modelo de análise do perfil de expressão gênica das linhagens selvagem e mutante $m a k-2^{\mathrm{ko}}$, cultivadas em baixa $(\downarrow)$ e alta $(\uparrow)$ concentrações de Pi.

\subsubsection{Cultivo em meio líquido de Fries (Crocken e Nyck, 1963)}

Para as análises de expressão gênica diferencial por microarranjos foram realizados 4 cultivos independentes, para cada condição utilizada neste estudo. Para isso, os conídios das linhagens selvagem e mutante $m a k-2^{\mathrm{ko}}$, crescidas no meio sólido de Vogel, foram colhidos em $15 \mathrm{ml}$ de água destilada esterilizada. Para remoção das hifas, a suspensão foi filtrada através de lã de vidro esterilizada e o número de conídios foi estimado pela contagem em câmara de Neubauer ao microscópio. A suspensão de conídios foi inoculada 
em meio líquido de Fries (Crocken e Nyck, 1963), numa concentração final de $10^{6}$ conídios/mL de meio. As linhagens selvagem e mutante $m a k-2^{\mathrm{ko}}$ foram então cultivadas a $30^{\circ} \mathrm{C}$ sob agitação por 5 horas, nas condições de Pi-limitante $(10 \mu \mathrm{M})$ ou Pi-saturante $(15$ mM). O pH do meio foi ajustado para 5,4. Após esse período, os micélios de cada condição foram recolhidos por filtração, lavados com água tratada com DEPC (Sambrook et al., 1989), prensados entre folhas de papel filtro para remover o excesso de água, congelados em nitrogênio líquido e armazenados a $-80^{\circ} \mathrm{C}$ até extração de RNA total.

\subsubsection{Extração de RNA total}

RNA total foi extraído usando o kit illustra RNAspin mini (GE Healthcare) como descrito no item 3.3.2. Após tratamento com DNAse e purificação com o kit RNAeasy (Qiagen), a qualidade do RNA total foi verificada pela tecnologia Agilent (Bioanalyser 2.100, Agilent Technologies) que inclui a separação eletroforética num chip miniaturizado. A concentração e pureza do RNA foram quantificadas através da leitura de absorbância a 260 e $280 \mathrm{~nm}$.

\subsubsection{Lâminas de microarranjos de oligonucleotídeos}

As lâminas de microarranjos foram obtidas do FGSC, (http://www.fgsc.net/NeurosporaCrassaMicroarrays.htm). As mesmas são constituídas de 10.910 seqüências de oligonucleotídeos de 70 bases, sendo que 10.526 correspondem a ORFs (Open Reading Frames) preditas de $N$. crassa e 384 correspondem a regiões teloméricas ou intergênicas utilizadas no processo de normalização dos dados. 


\subsubsection{Marcação das sondas complexas de cDNA com fluorocromos Cy3 e Cy5}

Amostras de RNA foram convertidas a cDNA e marcadas utilizando o kit ChipShot $^{\mathrm{TM}}$ Indirect Labeling and Clean-Up System (Promega) que envolve a preparação e adequação do cDNA em dois passos. No primeiro passo ocorre a síntese da primeira fita de cDNA com a incorporação de nucleotídeos amino-alil dUTP modificados, com posterior degradação da cadeia de RNAm e purificação do cDNA para remoção de nucleotídeos livres e oligômeros. No segundo passo, o cDNA é marcado com formas reativas de ésteres NHS Cy3 e Cy5 (GE Healthcare) que se ligam aos nucleotídeos modificados e após um processo de purificação para eliminação dos CyDye não incorporados, a sonda está pronta para a hibridação.

\subsubsection{Quantificação do CyDye incorporado ao cDNA}

Após a purificação do cDNA marcado, foi feito o monitoramento da incorporação dos fluorocromos através da leitura em espectrofotômetro (NanoDrop ${ }^{\circledR}$ ND-1000). Foi utilizado $1 \rho$ mol de sonda marcada para cada $\mu 1$ de solução de hibridação.

\subsubsection{Hibridação em lâminas de vidro}

As sondas de cDNA marcadas com Cy3 e Cy5 foram misturadas e secas em speedvac a $30^{\circ} \mathrm{C}$. Imediatamente antes da hibridação, as mesmas foram resuspendidas num volume total de $50 \mu 1$ de solução de hibridação (Microarray hybridization buffer-Corning), incubados a $92^{\circ} \mathrm{C}$ por 5 minutos para denaturação do cDNA e centrifugados por 2 minutos a $10.000 \times \mathrm{g}$. A hibridação das lâminas de microarranjos com as sondas marcadas, e todas as etapas de lavagem foram realizadas conforme as instruções do fabricante. 
Cada uma das 4 réplicas biológicas foi hibridada em duplicata utilizando-se o sistema inverso de incorporação de nucleotídeos conjugados aos fluorocromos Сy3 e Сy5 dyes (dye-swap). A inversão de corantes para marcação da mesma amostra, foi utilizada a fim de controlar possíveis artefatos resultantes da incorporação preferencial de um dos análogos fluorescentes. Como estamos fazendo comparações entre amostras idênticas, espera-se que obtenhamos medidas consistentes, isto é, sem variações. Portanto, sinais de hibridação correspondentes à expressão de um mesmo gene, cuja energia tenha sido diferente entre a mesma amostra marcada com os diferentes fluorocromos, serão eliminados das análises futuras (Figura 5). Como cada microarranjo contem 4 réplicas para cada sonda, foram geradas 8 réplicas das medidas de intensidade de cada transcrito, para cada amostra analisada.

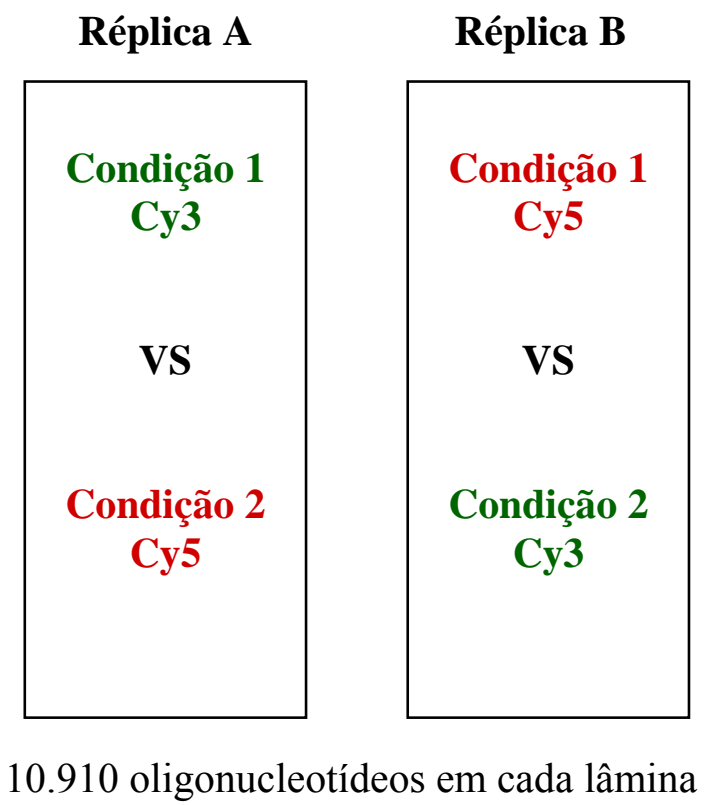

Figura 5. Representação esquemática das hibridações realizadas. Amostras da linhagem selvagem em condições de alto Pi $(15 \mathrm{mM})$ e da linhagem selvagem em condições de baixo $\mathrm{Pi}(10 \mu \mathrm{M})$ foram marcadas com fluorocromos distintos (Cy3 ou Cy5) e hibridadas na mesma lâmina (Réplica A). Foi realizada também uma segunda hibridação em outra lâmina (Réplica B), na qual os fluorocromos foram invertidos (dye-swap). 


\subsubsection{Filtragem e normalização dos dados de expressão gênica}

Após a hibridação, as imagens dos microarranjos foram obtidas usando o GenePix 4000B scanner (Axon Instruments, CA). As intensidades de fluorescência de Cy3 e Cy5 de cada sonda foram extraídas usando o programa GenePixPro6 (Axon Instruments, CA). Esse programa, além de transformar as informações das imagens em valores numéricos, também analisa a qualidade dos pontos e calcula o ruído (background). Dois parâmetros foram considerados para o controle de qualidade neste programa: os pontos de boa qualidade apresentam valores superiores e/ou igual a 1 valor do background mais 2 valores de desvio padrão. Para cada lâmina, as intensidades de Cy3 e Cy5, subtraídas do background, foram normalizadas. A normalização retira os erros experimentais sistemáticos para balancear a intensidade dos fluorocromos. Esses erros podem ocorrer devido à diferença de incorporação dos corantes, efeitos espaciais na lâmina e diferenças durante a aquisição das imagens nos dois canais (Quackenbush, 2002). Para esses ajustes, utilizou-se o algoritmo LOWESS (local weight regression).

Posteriormente, o programa SAM (Significance Analysis of Microarrays) (Tusher et al., 2001) foi utilizado para a identificação dos genes diferencialmente expressos. O programa SAM representa uma evolução dos softwares de análise estatística para a tecnologia de microarranjos e encontra-se disponível no endereço (http://wwwstat.stanford.edu/ tibs/SAM/). A ferramenta SAM busca identificar genes diferencialmente expressos com significância estatística entre conjuntos de experimentos de microarranjo, através de permutações repetidas dos dados de expressão de cada transcrito, entre as amostras de dois ou mais grupos que estão sendo comparados. Para cada gene, o valor real da correlação, medida entre os grupos (valor observado), é comparado a um valor de correlação obtido através de permutações dos dados (valor esperado ao acaso) para checar 
o valor estatístico associado ao conjunto de transcritos encontrado como diferencialmente expresso entre duas condições analisadas. Se o valor de correlação excede o valor esperado, a diferença de expressão é considerada significativa. O programa também calcula uma taxa de falsa descoberta (False Discovery Rate - FDR), que expressa a porcentagem de falso-positivos dentro do grupo de transcritos considerados diferencialmente expressos. A ferramenta permite ainda a seleção de conjuntos de transcritos usando limiares de FDR definidos pelo usuário. 


\section{RESULTADOS E DISCUSSÃ O}

\subsection{Identificação de genes diferencialmente expressos na linhagem mutante nuc-2A de Neurospora crassa através de SSH}

\subsubsection{Construção das bibliotecas de subtração de cDNAs}

Visando entender a funcionalidade do gene nuc-2 como um componente da via de transdução de sinal em resposta aos níveis de Pi exógeno, foram construídas duas bibliotecas de subtração de cDNAs. A primeira biblioteca tem o objetivo de identificar os genes induzidos pela proteína NUC-2 (Biblioteca NUC-2 I), utilizando os RNAm da linhagem selvagem de $N$. crassa isolados após o crescimento em condições de baixo Pi $(10 \mu \mathrm{M})$ e pH ácido $(\mathrm{pH} 5,4)$ como teste, e os RNAm da linhagem mutante $n u c-2 \mathrm{~A}$, cultivada nas mesmas condições, como controle. Na segunda biblioteca utilizamos os RNAm da linhagem mutante nuc-2A de $N$. crassa isolados após crescimento em condições de baixo Pi $(10 \mu \mathrm{M})$ e pH ácido $(\mathrm{pH} 5,4)$ como teste, e os RNAm da linhagem selvagem como controle, construída com o objetivo de identificar os genes reprimidos pela proteína NUC-2 de N. crassa (Biblioteca NUC-2 R). A estratégia usada para a construção das bibliotecas está descrita na Tabela 1.

Tabela 1. Estratégia usada para a construção das bibliotecas subtrativas de cDNA.

\begin{tabular}{|c|c|c|}
\hline \multirow{2}{*}{ Bibliotecas } & \multicolumn{2}{|c|}{ Teste } \\
\hline \multirow{2}{*}{ NUC-2 I } & $\begin{array}{c}\text { Linhagem St.L.74A cultivada em } \\
\text { Pi limitante e pH 5,4 }\end{array}$ & $\begin{array}{c}\text { Linhagem } n u c-2 A \text { cultivada em Pi } \\
\text { limitante e pH 5,4 }\end{array}$ \\
\hline \multirow{2}{*}{ NUC-2 R } & $\begin{array}{c}\text { Linhagem } \text { nuc-2A cultivada em } \\
\text { Pi limitante e pH 5,4 }\end{array}$ & $\begin{array}{c}\text { Linhagem St.L.74A cultivada em } \\
\text { Pi limitante e pH 5,4 }\end{array}$ \\
\hline
\end{tabular}




\subsubsection{Confirmação da integridade do RNA total}

Um dos métodos de avaliação da qualidade do RNA total obtido é a quantificação da razão dos valores de espectrometria medidos a 260 e $280 \mathrm{~nm}$. Uma razão próxima a 2 indica uma ótima eficiência de extração de RNA já que há pouca contaminação com proteínas. As amostras de RNA total utilizadas na construção das SSH apresentaram uma razão 260/280 entre 1,9 e 2,0 indicando que nosso protocolo de extração de RNA é eficaz para obtenção de RNA livre de proteínas. Por outro lado, para avaliar a degradação do RNA total extraído foi definido como critério que as amostras deveriam apresentar uma razão de intensidade das bandas de RNA ribossomal $28 \mathrm{~S}$ e $18 \mathrm{~S}$ próxima a 2 , que indica uma preparação de RNA com ausência de degradação.

Para a síntese dos cDNAs das condições teste e controle foi utilizado $1 \mu \mathrm{g}$ de RNA total das linhagens selvagem St.L.74A e mutante $n u c-2 \mathrm{~A}$ de $N$. crassa, cultivadas por 5 horas a $30^{\circ} \mathrm{C}$ sob agitação. Após a síntese dos cDNAs fita dupla, realizou-se a digestão com a enzima RsaI. A Figura 6A apresenta os fracionamentos dos cDNAs em gel de agarose, antes e depois da digestão. Pode-se observar que, antes da digestão, a maioria dos fragmentos apresentou um tamanho entre 0,5-3 Kb e, após da digestão, entre 0,2-1,5 Kb. 


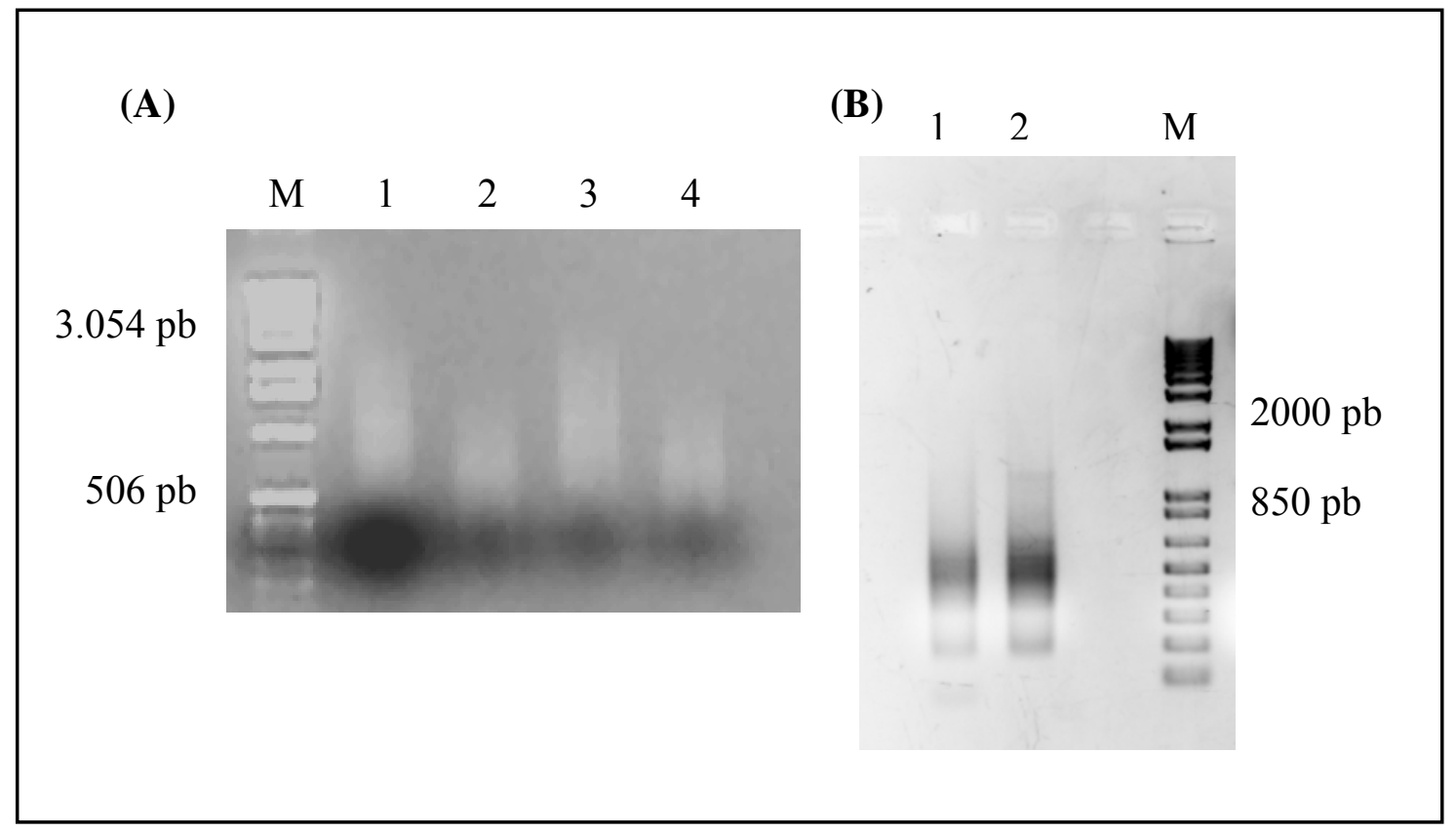

Figura 6. (A) Digestão do cDNA isolado das linhagens selvagem St.L.74A e mutante nuc2A com enzima RsaI. (1-2) cDNAs da linhagem St.L.74A antes e após a digestão, respectivamente; (3-4) cDNAs da linhagem nuc-2A antes e após a digestão, respectivamente. $\mathrm{M}=$ Padrão de massa molecular: $1 \mathrm{~Kb}$ DNA Ladder (Invitrogen). (B) Produto do PCR supressivo das SSHs. (1) Amplificação de genes induzidos pela proteína NUC-2; (2) Amplificação de genes reprimidos pela proteína NUC-2. M = Padrão de massa molecular: $1 \mathrm{~Kb}$ Plus DNA Ladder (Invitrogen).

Após a digestão, foram ligados adaptadores ( 1 e 2R) ao cDNA da condição teste, e realizadas as hibridações subtrativas para remoção das sequências expressas nas duas condições. Os transcritos diferencialmente expressos foram enriquecidos por PCR-Nested, utilizando os adaptadores ligados à região terminal dos fragmentos de cDNA da condição teste. Ao final, o produto do PCR supressivo foi submetido à eletroforese em gel de agarose, onde foram visualizados os fragmentos dos genes diferencialmente expressos (Figura 6B). Apenas fragmentos de maior massa molecular, compreendidos entre $300 \mathrm{e}$ $1.200 \mathrm{pb}$, foram recuperados do gel, purificados e clonados. 
No total, foram obtidos 600 clones da biblioteca NUC-2 I (teste = linhagem St.L.74A) e 362 clones da biblioteca NUC-2 R (teste = linhagem nuc-2A) que foram rastreados quanto à presença de insertos. A amplificação dos clones por PCR revelou que os fragmentos clonados apresentaram entre 200 e 1.000 pb (Figura 7).

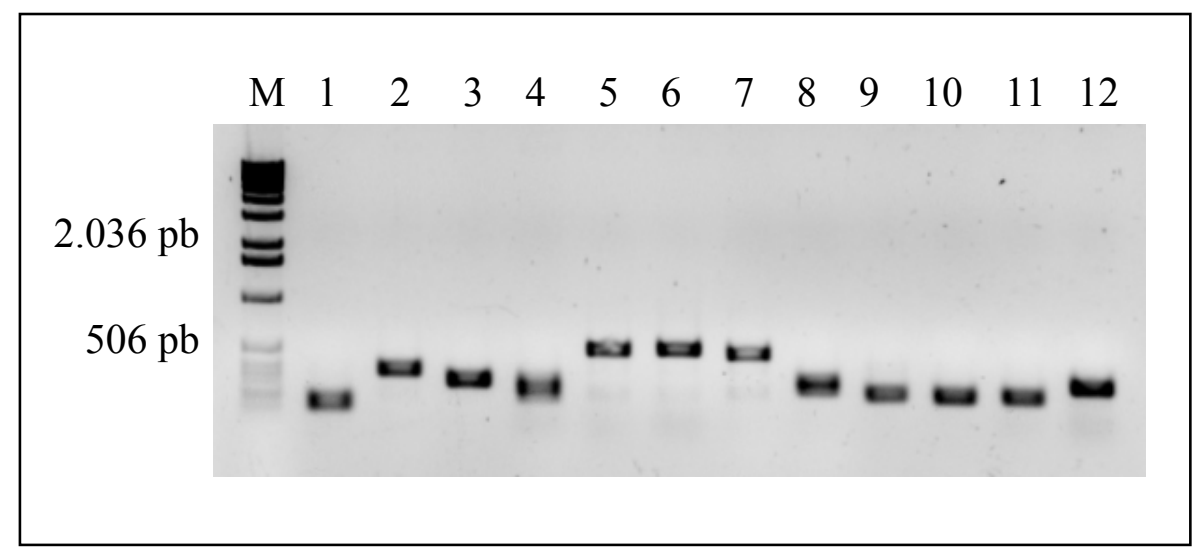

Figura 7. Eletroforese em gel de agarose $(1,2 \%)$ dos produtos de PCR, mostrando o tamanho dos insertos de uma amostra de clones oriundos da biblioteca NUC-2 I. M = Padrão de massa molecular: $1 \mathrm{~Kb}$ DNA Ladder (Invitrogen).

\subsubsection{Rastreamento das bibliotecas de subtração}

Com o objetivo de reduzir o número de clones falso positivos foi realizado um rastreamento das bibliotecas através de Northern blot reverso (Dilks et al., 2003). Para isso, quantidades iguais de cDNA amplificado dos clones isolados de cada biblioteca subtrativa foram transferidas para duas membranas de náilon e posteriormente, as mesmas foram hibridadas contra os cDNAs das condições teste e controle. O cDNA obtido por hibridação subtrativa foi utilizado como sonda, permitindo a detecção de mRNAs raros ou poucos expressos, o que não seria possível utilizando como sonda o cDNA total das linhagens. Dos 962 clones rastreados nas bibliotecas de subtração, 162 (16,8\%) tiveram sua expressão diferencial confirmada, enquanto que os restantes apresentaram sinal de 
hibridação equivalente quando comparadas as sondas da linhagem St.L.74A menos nuc-2A e nuc-2A menos St.L.74A. Os clones positivos foram selecionados considerando a presença ou ausência de sinal, assim como a diferença na intensidade para cada clone. Após um segundo ensaio de Northern blot reverso, utilizando somente os clones positivos no primeiro rastreamento, foram selecionados 96 (Figura 8) e 24 (Figura 9) clones de cDNA como reprimidos e induzidos, respectivamente, na linhagem mutante nuc-2A de $N$. crassa cultivada em condições de Pi-limitante $(10 \mu \mathrm{M})$ e pH ácido $(\mathrm{pH} 5,4)$.

Sonda St.L.74A

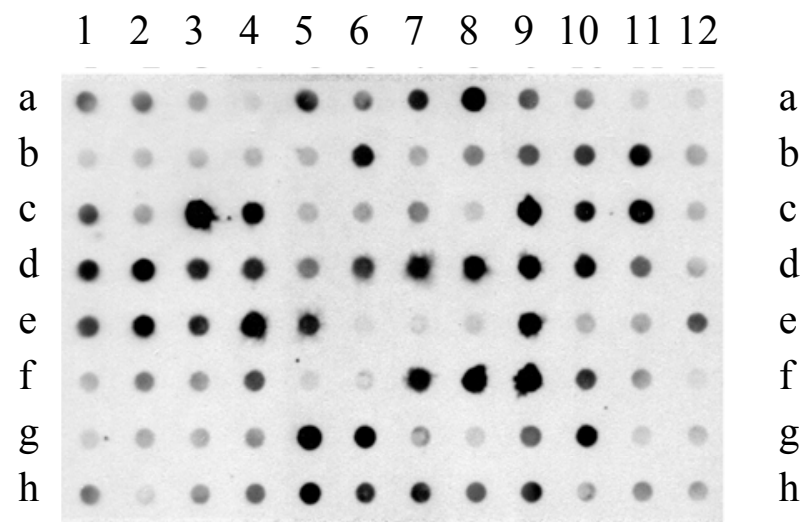

\section{Sonda nuc-2A}

$\begin{array}{lllllllllllll}1 & 2 & 3 & 4 & 5 & 6 & 7 & 8 & 9 & 10 & 11 & 12\end{array}$

a

b

$\mathrm{c}$

d

g

$\mathrm{h}$

Figura 8. Northern blot reverso. Membranas arranjadas com produto de PCR amplificado de 96 clones positivos no primeiro rastreamento da biblioteca NUC-2 I, hibridadas com sonda St.L.74A: cDNA subtraído a partir da linhagem St.L.74A cultivada sob baixo Pi; e com sonda nuc-2A: cDNA subtraído a partir da linhagem nuc-2A cultivada sob baixo Pi. 


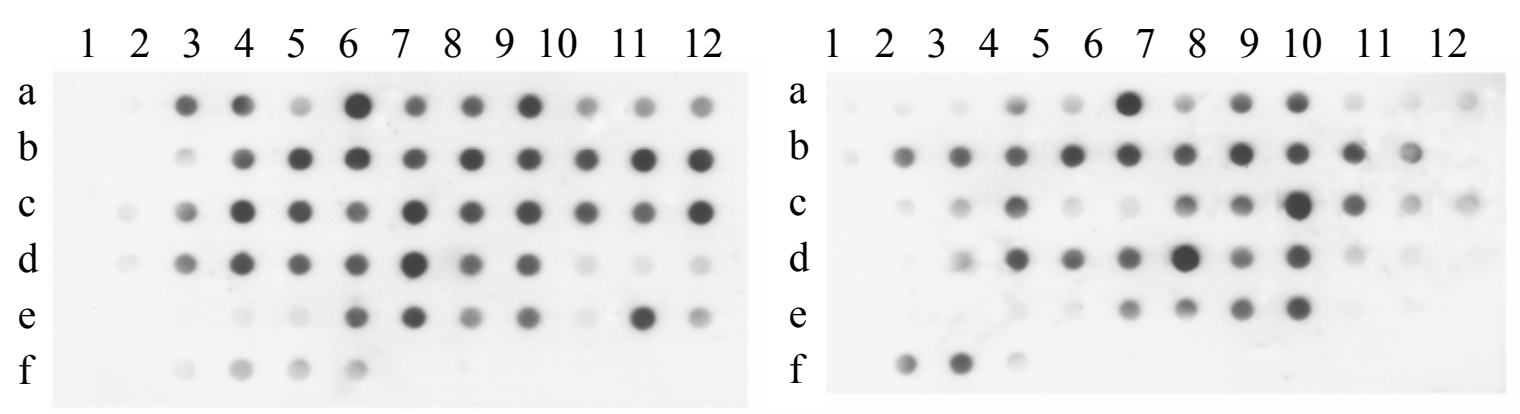

Figura 9. Northern blot reverso. Membranas arranjadas com produto de PCR amplificado de 66 clones positivos no primeiro rastreamento da biblioteca NUC-2 R, hibridadas com sonda St.L.74A: cDNA subtraído a partir da linhagem St.L.74A cultivada sob baixo Pi; e com sonda $n u c-2 \mathrm{~A}$ : cDNA subtraído a partir da linhagem nuc-2A cultivada sob baixo Pi.

\subsubsection{Análise por bioinformática dos clones selecionados}

As seqüências dos clones diferencialmente expressos foram primeiramente processadas pelos programas Phred e cross-match para verificação de qualidade e retirada do vetor. Após essas análises, foram excluídas todas as seqüências de má qualidade, sendo aceitas somente seqüências contendo mais de 50 bases com qualidade Phred acima de 20 . A anotação destas seqüências foi realizada com base nos bancos de dados de proteínas NR do NCBI, e no banco de dados do genoma de N. crassa. Estas análises identificaram 68 ESTs únicas, das quais, 52 correspondem a genes reprimidos na linhagem mutante $n u c-2 \mathrm{~A}$ (Tabela 2); as 16 ESTs restantes constituem genes induzidos na linhagem mutante $n u c-2 \mathrm{~A}$ (Tabela 3). Estas análises também mostraram que 5 sequências da biblioteca NUC-2 I, representando $8 \%$ das seqüências desta biblioteca, não apresentam similaridade com as ESTs depositadas no banco de dados de $N$. crassa. Sendo assim, as mesmas podem constituir novas ESTs de $N$. crassa. Entretanto, como em nosso trabalho as sequências 
foram obtidas após o cultivo da linhagem mutante $n u c-2 \mathrm{~A}$ de $N$. crassa em condições de baixo $\mathrm{Pi}$, podemos sugerir que essas ESTs com função desconhecida estão sendo de alguma forma reguladas pelo gene $n u c-2$.

Após estas comparações, as seqüências foram anotadas funcionalmente de acordo com as 20 principais categorias estabelecidas no FunCat (Mewes et al., 1997, 2002). Por se tratar de um esquema estruturalmente hierárquico e eficiente para anotação de dados gerados por estudos de genomas, transcriptomas e proteomas (Ruepp et al., 2006), este sistema de anotação tem sido amplamente utilizado para atribuir uma descrição funcional às seqüências de ESTs de diferentes fungos (Andrade et al., 2006, Guo et al., 2008, Silva et al., 2008). Através da classificação funcional dos genes reprimidos na linhagem mutante nuc-2A cultivada em Pi-limitante e pH ácido (biblioteca NUC-2 I), foi visto que $30 \%$ dos transcritos participam da síntese de proteínas, $21 \%$ codificam enzimas envolvidas no metabolismo celular, $6 \%$ desempenham funções relacionadas à transcrição, e 4\% participam do transporte celular (Tabela 2). A classificação funcional dos genes induzidos na linhagem mutante $n u c-2 \mathrm{~A}$ (biblioteca NUC-2 R) revelou que 51\% dos transcritos negativamente modulados foram classificados como envolvidos na síntese de proteínas. Entre os demais genes identificados, $13 \%$ participam no transporte celular, e $30 \%$ correspondem a transcritos que participam da comunicação celular e transdução de sinal, biogênese de componentes celulares, ciclo celular e processamento de DNA, metabolismo e endereçamento de proteínas (Tabela 3). 
Tabela 2. Genes com expressão diminuída na linhagem mutante nuc-2A cultivada em Pilimitante $(10 \mu \mathrm{M})$ e $\mathrm{pH}$ ácido (pH 5,4).

\begin{tabular}{|c|c|c|c|}
\hline $\mathbf{I D}^{\mathrm{a}}$ & $\begin{array}{l}\text { Nro. de } \\
\text { clones }\end{array}$ & Descrição & MIPS \\
\hline NCU08332 & 2 & Proteína hexagonal-1 (Hex-1) & 41 \\
\hline NCU03050 & 1 & Complexo ARP $2 / 3$, subunidade $34 \mathrm{kDa}$ & 14 \\
\hline NCU04924 & 1 & Fosfatidil sintase & 1 \\
\hline NCU06043 & 1 & Proteína hipotética similar a GPR-FUN34 & 1 \\
\hline NCU07930 & 1 & Adenosilhomocisteinase & 1 \\
\hline NCU00951 & 1 & Pirofosfatase inorgânica & 1 \\
\hline NCU02509 & 4 & Proteína ribossomal 60S L11 & 12 \\
\hline NCU02707 & 2 & Proteína ribossomal 60S L16a & 12 \\
\hline NCU03988 & 2 & Proteína ribossomal 60S L18 & 12 \\
\hline NCU10042 & 2 & Enolase & 1 \\
\hline NCU00258 & 2 & Proteína ribossomal 40S S7 & 12 \\
\hline NCU08940 & 1 & Citocromo $\mathrm{C}$ redutase & 2 \\
\hline NCU07829 & 1 & Proteína ribossomal 60S L7 & 12 \\
\hline NCU08500 & 1 & Proteína ribossomal 40S S8 & 12 \\
\hline NCU03302 & 1 & Proteína ribossomal 60S L36 & 12 \\
\hline NCU03565 & 1 & Proteína ribossomal 60S L26 & 12 \\
\hline NCU01633 & 1 & Transportador de hexose & 20 \\
\hline NCU00147 & 1 & Proteína hipotética similar a SIPL-ARD & 99 \\
\hline NCU01948 & 1 & Proteína ribossomal 60S L21 & 12 \\
\hline NCU03004 & 1 & Piruvato desidrogenase & 1 \\
\hline NCU09475 & 1 & Proteína ribossomal 40S S5 & 12 \\
\hline NCU08195 & 1 & Arginil-tRNA sintetase & 12 \\
\hline NCU02729 & 1 & Proteína repetida WD & 11 \\
\hline NCU02010 & 1 & 2- Isopropilmalato sintase & 1 \\
\hline NCU03827 & 1 & Proteína ribossomal 40S S9 & 12 \\
\hline NCU01068 & 1 & Proteína hipotética conservada & 99 \\
\hline NCU02274 & 1 & Serina hidroximetiltransferase & 1 \\
\hline NCU04542 & 1 & Proteína predita & 99 \\
\hline
\end{tabular}




\begin{tabular}{|c|c|c|c|}
\hline NCU04552 & 1 & Proteína ribossomal 40S S26 & 12 \\
\hline NCU01635 & 1 & Histona $\mathrm{H} 3$ & 11 \\
\hline NCU06207 & 1 & C-5 esterol desaturase & 1 \\
\hline NCU09331 & 1 & Proteína BRT1 & 34 \\
\hline NCU04779 & 1 & Proteína ribossomal 60S L8 & 12 \\
\hline NCU06090 & 1 & $\begin{array}{l}\text { Relacionada com RRP14 - envolvida em } \\
\text { processamento do RNA ribossomal }\end{array}$ & 99 \\
\hline NCU02380 & 1 & Treonil-tRNA sintetase & 12 \\
\hline NCU08502 & 1 & Proteína ribossomal 40S S6 & 12 \\
\hline NCU01195 & 2 & NADH desidrogenase & 1 \\
\hline NCU04603 & 1 & Proteína predita relacionada ao alérgeno rasp f7 & 1 \\
\hline NCU02514 & 1 & ATP-sintase & 20 \\
\hline NCU01523 & 1 & GTP - Proteína de união ypt3 & 30 \\
\hline NCU05231 & 1 & Proteína hipotética & 99 \\
\hline NCU11339 & 1 & Proteína predita & 99 \\
\hline NCU00212 & 1 & Histona $\mathrm{H} 4$ & 11 \\
\hline NCU01991 & 1 & Proteína predita & 99 \\
\hline NCU01559 & 1 & Proteína predita & 99 \\
\hline NCU05667 & 1 & Proteína predita & 99 \\
\hline \multirow[t]{6}{*}{ NCU02066 } & 1 & Proteína de reparo RAD4 & 10 \\
\hline & 1 & Mitochondria, assembly 3 (20731-20584) & 99 \\
\hline & 1 & Contig 7 (759234-759438) & 99 \\
\hline & 1 & Contig 1 (1304801-1304929) & 99 \\
\hline & 1 & Contig 1 (1650053-1650170) & 99 \\
\hline & 1 & Contig 15 (117148-117217) & 99 \\
\hline
\end{tabular}

\footnotetext{
a Identificação dos genes no banco de dados de N. crassa (Broad Institute).

${ }^{\mathrm{b}}$ Classificação funcional utilizando o banco de dados MIPS: (1) metabolismo; (2) energia; (10) ciclo celular e processamento de DNA; (11) transcrição; (12) síntese de proteínas; (14) endereçamento de proteínas (dobramento, modificação e endereçamento); (20) transporte celular; (30) comunicação celular e transdução de sinal; (34) Interação com o ambiente; (41) desenvolvimento; (43) diferenciação celular; (99) proteínas não classificadas.
} 
Tabela 3. Genes com elevada expressão na linhagem mutante nuc-2A cultivada em Pilimitante $(10 \mu \mathrm{M})$ e $\mathrm{pH}$ ácido (pH 5,4).

\begin{tabular}{|c|c|c|c|c|}
\hline $\mathbf{I D}^{\mathrm{a}}$ & Clones $^{\mathbf{b}}$ & $\begin{array}{l}\text { Nro. de } \\
\text { clones }\end{array}$ & Descrição & MIPS $^{\mathrm{c}}$ \\
\hline NCU04553 & A7/F6 & 2 & Ubiquitina - Proteína ribossomal 40S S27 & 14 \\
\hline NCU02571 & A3 & 1 & Acetiltransferase Acetyl-CoA & 1 \\
\hline NCU08964 & A4 & 1 & Proteína ribossomal 60S L10 & 12 \\
\hline NCU07857 & A9 & 1 & Proteína ribossomal 60S L34 & 12 \\
\hline NCU08389 & A10 & 1 & Proteína ribossomal 60S L20 & 12 \\
\hline NCU09477 & A12 & 1 & Proteína carregadora de ATP/ADP & 20 \\
\hline NCU08620 & $\mathrm{C} 4$ & 1 & Proteína ribossomal 40S S16 & 12 \\
\hline NCU02393 & $\mathrm{C} 5$ & 1 & MAP quinase (mak-2) & 30 \\
\hline NCU03038 & $\mathrm{C} 6$ & 1 & Proteína ribossomal 40S S13 & 12 \\
\hline NCU00413 & $\mathrm{C} 8$ & 1 & Proteína ribossomal 60S L2 & 12 \\
\hline NCU03806 & $\mathrm{C} 12$ & 1 & Proteína ribossomal 60S L28 & 12 \\
\hline NCU07380 & D3 & 1 & Fator de iniciação eIF3d & 10 \\
\hline NCU00957 & A11 & 1 & Proteína da matriz extracelular & 42 \\
\hline NCU04736 & $\mathrm{C} 3$ & 1 & Cálcio-ATPase & 20 \\
\hline NCU02003 & $\mathrm{C} 7$ & 1 & Fator de elongação 1 alfa & 12 \\
\hline NCU02853 & E6 & 1 & Proteína hipotética & 99 \\
\hline \multicolumn{5}{|c|}{$\begin{array}{l}\text { a Identificação dos genes no banco de dados de N. crassa (Broad Institute). } \\
\text { b Identificação dos clones positivos mostrados na Figura 9. } \\
{ }^{\mathrm{c}} \text { Classificação funcional utilizando o banco de dados MIPS: (1) metabolismo; (10) ciclo } \\
\text { celular e processamento de DNA; (12) síntese de proteínas; (14) endereçamento de } \\
\text { proteínas (dobramento, modificação e endereçamento); (20) transporte celular; (30) } \\
\text { comunicação celular e transdução de sinal; (42) Biogênese de componentes celulares; (99) } \\
\text { proteínas não classificadas. }\end{array}$} \\
\hline
\end{tabular}




\subsubsection{Validação de genes reprimidos na linhagem mutante nuc-2A de $N$. crassa}

Para a confirmação da expressão diferencial dos clones selecionados após o rastreamento da biblioteca NUC-2 I foram realizados experimentos de Northern blot de 8 genes arbitrariamente escolhidos entre as 52 ESTs identificadas. A comparação da seqüência destes clones com proteínas depositadas no GeneBank e no banco de dados de N. crassa, revelaram similaridade com NADH desidrogenase (NCU01195), ATP-sintase (NCU02514), Proteína hexagonal-1 (HEX-1) (NCU08332), Transportador de hexose (NCU01633), Piruvato desidrogenase (NCU03004), Adenosilhomocisteinase (NCU07930), Histona H3 (NCU01635) e Histona H4 (NCU00212).

Para a realização deste ensaio, RNA de cada condição experimental foram submetidos à eletroforese em gel de agarose, transferidos para membrana de náilon e posteriormente hibridadas com as sondas do cDNA do clone a ter sua expressão diferencial confirmada. Para todas as sondas marcadas foi possível verificar a expressão diferencial, uma vez que as sondas destes genes hibridaram com maior intensidade contra as amostras de RNA extraído da linhagem selvagem St.L.74A cultivada em Pi limitante, quando comparada à linhagem mutante nuc-2A (Figura 10). 
NADH desidrogenase

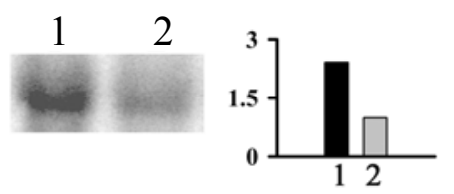

ATP sintase

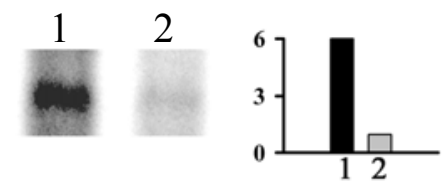

Histona 4

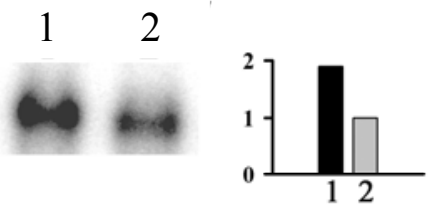

Transportador de hexose

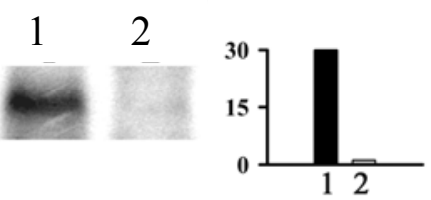

Proteína hexagonal-1 (HEX-1)

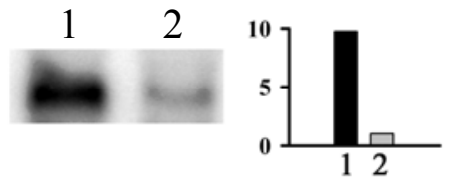

Piruvato desidrogenase

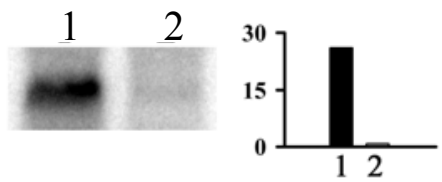

Adenosilhomocisteinase

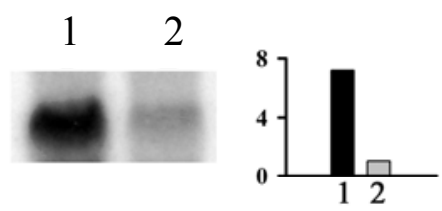

Histona 3

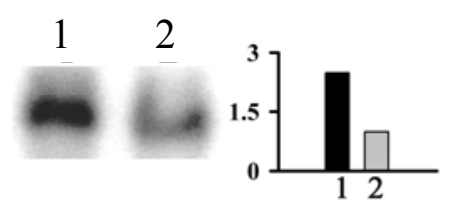

Figura 10. Confirmação por Northern blot dos genes reprimidos na linhagem mutante nuc-2A. (1) RNA da linhagem selvagem cultivada em condições Pi-limitante; (2) RNA da linhagem mutante nuc-2A cultivada em condições de Pi-limitante. RNA ribossomal foi visualizado com brometo de etídio para comparação das quantidades utilizadas. Os gráficos indicam a intensidade relativa dos sinais de hibridação das marcações mostradas por Northern blot de alguns genes expressos na linhagem selvagem (barra 1) e mutante $n u c-2 \mathrm{~A}$ (barra 2), como estabelecido por análise densiométrica. 


\section{Expressão diferencial de genes envolvidos na transcrição: Histonas 3 e 4.}

O perfil de expressão dos mRNAs das histonas H3 (NCU01635) e H4 (NCU00212) obtidos na SSH NUC-2 I foi validado por Northern blot. Os resultados demonstraram que a linhagem mutante nuc-2A cultivada em Pi-limitante, apresenta uma diminuição nos níveis de expressão dos genes que codificam as histonas 3 e 4 (H3 e H4) quando comparada à linhagem selvagem St.L.74A.

O genoma de eucariotos é organizado em uma estrutura conhecida como cromatina, constituída da molécula de DNA genômico e proteínas. As proteínas mais abundantes associadas com o DNA de eucariotos são as histonas, uma família de proteínas altamente conservadas ao longo da evolução, dentre as quais, podemos mencionar H1, H2A, H2B, $\mathrm{H} 3 \mathrm{e}$ e H4. O filamento de DNA (contendo aproximadamente $146 \mathrm{pb}$ ) contorna, por duas vezes, um octâmero de histonas (composto de 2 unidades de H2A; H2B; H3 e H4), numa estrutura conhecida como nucleossomo (Fletcher e Hansen, 1996; Wolffe e Hayes, 1999; Millar e Grunstein, 2006). Em cada um destes nucleossomos liga-se a histona H1, responsável por manter esta estrutura enovelada, permitindo a compactação do DNA e formação do cromossomo. Em S. cerevisiae, foi observado que a depleção da histona H4 induz alterações na expressão de aproximadamente $25 \%$ dos genes desta levedura (Wyrick et al., 1999). Por outro lado, Han et al. (1998) reportaram que mutantes de $S$. cerevisiae com os genes da histona H4 inativos apresentaram uma forte ativação transcricional do gene pho-5 sugerindo que o nucleossomo atua como um regulador negativo da fosfatase ácida.

Sendo assim, parece evidente que a diminuição nos níveis de expressão das histonas $\mathrm{H} 3$ e $\mathrm{H} 4$ na linhagem mutante $n u c-2 \mathrm{~A}$ de $N$. crassa em condições de baixo Pi, pode ser um dos mecanismos utilizados pelo fungo para regular a transcrição durante o processo de adaptação às mudanças do meio ambiente. Além disso, a redução na expressão 
destes transcritos na linhagem nuc-2A sugere uma regulação positiva, direta ou indireta, por $n u c-2$.

\section{Expressão de genes envolvidos no processo de conversão de energia.}

Nossos resultados também mostraram que vários transcritos envolvidos no processo de fosforilação oxidativa apresentam uma diminuição nos níveis de expressão na linhagem mutante nuc-2A, em relação à linhagem selvagem St.L.74A. Esse importante processo biológico é responsável pela síntese de ATP a partir da energia liberada pelo transporte de elétrons na cadeia respiratória.

O nível de expressão da enzima NADH desidrogenase (NCU01195) foi 1,8 vezes menor no mutante nuc-2A quando comparado com a linhagem selvagem. Sabe-se que esse gene codifica uma proteína pertencente à cadeia de transporte de elétrons, e é responsável pelo aumento de prótons no espaço intermembrana da mitocôndria. Observamos ainda por Northern blot reverso que a expressão do gene que codifica a citocromo $\mathrm{C}$ redutase (NCU08940) foi reduzida na linhagem mutante. O citocromo C é uma outra enzima que faz parte do transporte de elétrons da cadeia respiratória.

Alem disso, verificamos que o nível de expressão dos transcritos da ATP-sintase também foi menor na linhagem mutante nuc-2A de $N$. crassa cultivada em baixo Pi. ATPsintase é uma proteína transmembrana multi-subunidades com uma massa molecular de $450 \mathrm{kDa}$, que catalisa a síntese de ATP a partir de ADP e fosfato inorgânico na mitocôndria, através do fluxo dos prótons em favor do gradiente eletroquímico gerado. Em células eucarióticas foi relatado que um aumento de Pi intracelular pode ser conseqüência do gradiente eletroquímico gerado na membrana plasmática através da $\mathrm{H}^{+}$-ATPase ou ATP-sintase (Giots et al., 2003; Mouillon e Persson, 2006). Portanto, nossos resultados 
sugerem que uma redução na expressão de vários genes envolvidos no processo de fosforilação oxidativa na linhagem mutante nuc-2A parece ser uma das estratégias utilizadas por $N$. crassa para captar Pi extracelular, e que a expressão destes genes depende da sinalização por NUC-2.

\section{Corpos de Woronin.}

Os corpos de Woronin são vesículas densas associadas ao poro septal, essenciais para prevenir a perda excessiva de citoplasma após uma injúria celular e evitar o comprometimento do desenvolvimento (Markham e Collinge, 1987; Soundararajan et al., 2004; Tey et al., 2005). Caracterizados como peroxissomos especializados, os corpos de Woronin possuem como componente principal a proteína HEX-1, recentemente identificada em N. crassa e outros fungos filamentosos, incluindo Magnaporthe grisea, Trichoderma reesei e Aspergillus oryzae (Tenney et al., 2000; Jedd e Chua, 2000; Soundararajan et al., 2004; Curach et al., 2004; Maruyama et al., 2005). Experimentos de Western blot em $N$. crassa demonstraram que HEX-1 é uma proteína de 19 kDa. Além disso, a análise da proteína HEX-1 purificada indicou que 16 resíduos são clivados, formando um polipeptídeo de $17 \mathrm{kDa}$ (Tenney et al., 2000).

O gene que codifica a HEX-1 (NCU08332), componente principal dos corpos de Woronin, foi identificado na biblioteca NUC-2 I. Os resultados de Northern blot demonstraram que a linhagem mutante nuc-2A cultivada em Pi limitante, apresenta uma diminuição nos níveis de expressão de hex-1 quando comparada à linhagem selvagem St.L.74A. Mediante ensaios de microarranjos foi também observado um aumento dos níveis deste transcrito na linhagem selvagem St.L.74A cultivada em concentrações limitantes Pi. O efeito da limitação de nutrientes na expressão de hex-1, como observado 
aqui para limitação de $\mathrm{Pi}$, foi demonstrado também em $M$. grisea, porém em relação à limitação de nitrogênio. Neste fitopatógeno o aumento nos níveis do transcrito hex-1 foi regulado pela privação de nitrogênio e pelas condições ambientais encontradas na planta hospedeira durante a infecção. Além disso, a inativação do gene hex-1 em M. grisea afetou a eficiência da patogenicidade e a sobrevivência do patógeno durante a privação de nitrogênio. Estes estudos, concomitante com os obtidos em N. crassa, sugerem que os corpos de Woronin desempenham um importante papel na adaptação dos fungos a condições ambientais adversas (Soundararajan et al., 2004). É importante ressaltar que em N. crassa o gene hex-1 é regulado transcricionalmente por nuc-2, em função da limitação de Pi.

\section{Transportador de açúcar.}

Outro gene negativamente regulado na linhagem mutante nuc-2A foi o transportador de hexose (NCU01633). Os transportadores são proteínas transmembrana envolvidas na captação de nutrientes e secreção celular. Essas proteínas exercem um importante papel fisiológico, transportando aminoácidos, açúcares, íons, lipídios, cofatores e outros substratos essenciais. Os sistemas de transporte mais freqüentes nos organismos podem ser divididos em dois grupos: transportadores $\mathrm{ABC}$ (ATP-binding cassette) e transportadores MFS (Major Facilitator Superfamily). O primeiro grupo corresponde a transportadores ativos de íons inorgânicos, açúcares e polipeptídios em resposta a hidrólise de ATP. Por sua parte, os transportadores MFS captam somente pequenos solutos em resposta ao gradiente osmótico da célula. O transportador de hexose, altamente reprimido na linhagem mutante $n u c-2 \mathrm{~A}$, constitui um transportador MFS. 
Em S. cerevisiae foi observado que a presença de glicose no meio é requerida para um efetivo monitoramento de Pi extracelular, sugerindo uma integração da informação proveniente destes diferentes sistemas de monitoramento (Giots et al., 2003). Este fato sugere que a expressão deste transportador na linhagem selvagem de $N$. crassa em condições de baixo Pi pode estar relacionada com a captação de glicose necessária para uma adaptação eficaz dos fungos em condições adversas. Além disso, a acentuada redução na expressão deste transportador na linhagem nuc-2A sugere que as vias de sinalização do fosfato e da glicose possam estar sobrepostas também em $N$. crassa.

\subsubsection{Transcritos regulados pelo gene nuc-2 em função do nível exógeno de Pi}

Para verificar se os genes positivamente regulados pela proteína NUC-2 se correlacionam com os transcritos modulados pela concentração de Pi, foram confrontados os resultados obtidos nos ensaios de $\mathrm{SSH}$ e microarranjos. Nestes experimentos foi comparado o perfil de expressão gênica da linhagem selvagem St.L.74A cultivada em condições de Pi-limitante e Pi-saturante, em meio ácido. Os resultados obtidos mostraram que $77 \%$ dos transcritos com níveis de expressão diminuídos na linhagem mutante nuc-2A de N. crassa, também se apresentaram modulados pelo nível exógeno de Pi. Entretanto, apenas 13\% desses genes (de NCU08332 até NCU00951 da Tabela 2) foram induzidos em condições de baixo Pi, e 64\% (de NCU02509 até NCU08502 da Tabela 2) foi induzido em condições de Pi-saturante. Embora o restante dos genes não tenha sido regulado em função do $\mathrm{Pi}$, nossos experimentos de $\mathrm{SSH}$ indicaram que eles são regulados pela proteína NUC-2. De fato, Leal et al. (2007) mostraram que os genes nuc-1 e preg atuam direta ou indiretamente na modulação de outros transcritos além daqueles conhecidos como envolvidos na aquisição de $\mathrm{Pi}$, destacando genes implicados no metabolismo de nucleotídeos. Sendo assim, os nossos resultados sugerem que, igual ao anteriormente 
proposto para os genes nuc-1 e preg, o gene nuc-2 também possa estar envolvido em outros processos metabólicos. Nossos dados sugerem ainda que o gene nuc-2 além de reprimir genes em concentrações limitantes de $\mathrm{Pi}$, participa na regulação de transcritos em condições de alto fosfato.

\subsubsection{Validação dos genes induzidos na linhagem mutante nuc-2A de $N$. crassa}

Para confirmação da expressão diferencial dos transcritos selecionados após o rastreamento da biblioteca NUC-2 R foram realizados experimentos de Northern blot virtual e Northern blot de 4 genes escolhidos arbitrariamente entre as 16 ESTs identificadas (Figura 10). A comparação da seqüência destes clones no programa BLASTx do GeneBank, revelou homologia com ubiquitina - proteína ribossomal 40S S27 (clone A7/F6, NCU04553), proteína ribossomal 40S S16 (clone C4, NCU08620), proteína ribossomal 40S S13 (clone C6, NCU03038) e fator de iniciação eIF3d (clone D3, NCU07380).

Para a realização do experimento de Northern blot virtual, $3 \mu \mathrm{g}$ de cDNA obtido de cada condição experimental foram transferidos para membrana de náilon e posteriormente, as mesmas foram hibridadas com a sonda de cDNA do clone a ser confirmado. A normalização da quantidade de cDNA de cada amostra foi realizada por hibridação das membranas com o gene constitutivo da $\beta$-tubulina de $N$. crassa (Figura 11a). Os resultados obtidos por Northern blot virtual foram validados por experimentos de Northern blot. Entretanto, nestes experimentos, a expressão dos genes foi analisada também na linhagem selvagem cultivada em condições de Pi-saturante $(15 \mathrm{mM})$, com o intuito de verificar se a linhagem $n u c-2 \mathrm{~A}$ responde da mesma maneira que a linhagem selvagem cultivada em Pi suficiente (Figura 11b). 


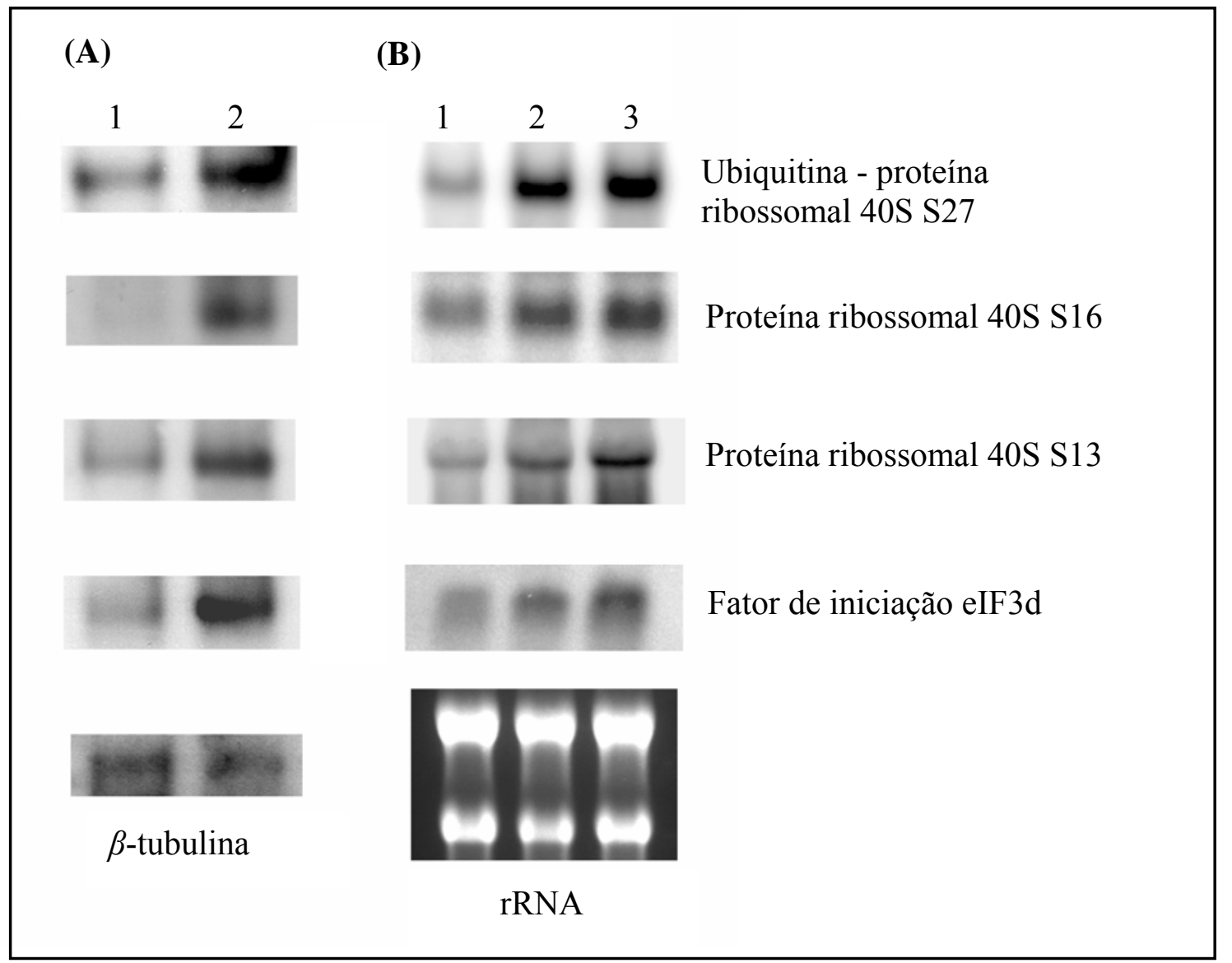

Figura 11. Confirmação da expressão dos genes induzidos na linhagem mutante nuc-2A. (A) Análise por Northern blot virtual. (1) cDNA da linhagem selvagem; (2) cDNA da linhagem mutante nuc-2A. (B) Análise por Northern blot. (1) RNA da linhagem selvagem cultivada em condições de baixo Pi; (2) RNA da linhagem mutante nuc-2A cultivada em condições de baixo Pi; (3) RNA da linhagem selvagem cultivada em condições de alto Pi. As bandas de RNA ribossomal foram mostradas para controle da quantidade de RNA colocada em cada poço. 


\section{Expressão diferencial de genes envolvidos na tradução.}

O perfil de expressão dos mRNAs do fator de iniciação eIF3d (NCU07380) obtido na SSH NUC-2 R foi validado por Northern blot. Os resultados mostraram que a linhagem mutante nuc-2A cultivada em Pi limitante apresenta um aumento nos níveis de expressão deste transcrito quando comparada à linhagem selvagem St.L.74A. Foi também observado que o gene eIF3d foi induzido na linhagem selvagem cultivada em Pi-saturante, indicando que este transcrito é regulado negativamente por NUC-2, em função da concentração do Pi no meio.

O inicio da síntese de proteínas consiste no recrutamento do complexo ribossomotRNA iniciador para o códon de iniciação do mRNA. Em procariotos, três fatores peptídicos (IF1, IF2 e IF3) são necessários para o inicio da tradução. Já em eucariotos, este é um processo complexo envolvendo interações proteína-RNA e proteína-proteína, o qual requer a participação coordenada de inúmeros fatores de iniciação (eIFs) para o correto funcionamento da maquinaria de síntese de proteínas (Pestova et al., 2001).

O fator de iniciação eIF3 (eIF3) foi primeiramente isolado e purificado como um complexo de alto peso molecular de reticulócitos de coelho (Benne e Hershey, 1976). A função do eIF3 tem sido elucidada por uma variedade de experimentos in vitro. Ele se liga diretamente à subunidade ribossomal 40S na ausência de outros componentes da iniciação da tradução e afeta a associação/dissociação dos ribossomos. Além disso, o eIF3 promove a ligação do Metionil-tRNA iniciador (Met-tRNAi) e mRNA à subunidade ribossomal 40S. Assim, o eIF3 tem um papel central na via de iniciação, organizando estruturalmente outros componentes traducionais na superfície da subunidade ribossomal 40S (Hinnebusch, 2006). 
O eIF3 de mamíferos possui massa molecular de aproximadamente $600 \mathrm{kDa}$ sendo formado por 12 subunidades, nomeadas de acordo com a ordem decrescente de massa molecular: eIF3a, eIF3b, eIF3c, eIF3d, eIF31, eIF3e, eIF3f, eIF3g, eIF3h, eIF3i, eIF3j e eIF3k (Browning et al., 2001; Morris-Desbois et al., 2001).

Em Schizosaccharomyces pombe, foi identificado um grupo de cinco subunidades centrais componentes do eIF3. Estas subunidades são essenciais para o crescimento celular e, são ortólogas às subunidades eIF3a, eIF3b, eIF3c, eIF3g, eIF3i de mamíferos. Além destas, ainda existem as subunidades não essenciais eIF3d, eIF3e, eIF3h, as quais se associam ao complexo central do eIF3 de $S$. pombe. Foi proposto que uma combinação das subunidades essenciais com distintas subunidades não essenciais permitem a regulação específica da tradução de diferentes mRNAs em leveduras (Zhou et al., 2005). Outros dois genes identificados na SSH NUC-2 R e confirmados por Northern blot foram os transcritos que codificam as proteínas ribossomais S13 (NCU03038) e S16 (NCU08620), constituintes da subunidade 40S do ribossomo.

Assim, o aumento da expressão de eIF3d e das subunidades ribossomais 40S (S13 e S16) na linhagem mutante $n u c-2 \mathrm{~A}$ pode representar um mecanismo para regular em $N$. crassa o recrutamento de mRNAs específicos envolvidos no processo de adaptação às mudanças do meio ambiente. Desta maneira, estes transcritos também podem ser responsáveis pela regulação das fosfatases Pi-repressíveis já que os mesmos foram mais expressos na linhagem com o gene nuc-2 inativado e quando a linhagem selvagem foi cultivada na presença de concentrações suficientes de Pi (Metzenberg, 1979). Além disso, o aumento da expressão destas ESTs na linhagem nuc-2A sugere que este gene pode estar regulando direta ou indiretamente a expressão destes transcritos, em função da disponibilidade de Pi. 
Para verificar se os genes negativamente regulados pela proteína NUC-2 também respondem à disponibilidade de $\mathrm{Pi}$, foram confrontados os resultados obtidos nos ensaios de $\mathrm{SSH}$ com os de microarranjos. Conforme mencionado, nos experimentos de microarranjos foi comparado o perfil de expressão gênica da linhagem selvagem St.L.74A cultivada em condições de Pi-limitante e Pi-saturante, em meio ácido. Os resultados mostraram que $81 \%$ dos transcritos com expressão elevada na linhagem mutante $n u c-2 \mathrm{~A}$ de N. crassa (de NCU04553 até NCU07380 da Tabela 3) se apresentaram induzidos na linhagem selvagem em condições de Pi-saturante. Estes resultados coincidem com os obtidos por Northern blot, e sugerem que estes transcritos são regulados pela proteína NUC-2 em função da concentração de Pi.

\subsection{Identificação de genes expressos em resposta ao Pi e análise do envolvimento de} MAK-2 no monitoramento do Pi extracelular em Neurospora crassa

O transcrito que codifica para a MAP quinase-2 (mak-2 - NCU02393) foi identificado após experimento de $\mathrm{SSH}$, se mostrando negativamente regulado pelo gene nuc-2 (Tabela 3, Gras et al., 2007). Como pode ser observado na Figura 12, este gene também é expresso quando a linhagem selvagem é cultivada em concentrações suturantes de Pi.

As MAP quinases são enzimas altamente conservadas nos organismos eucariotos e estão envolvidas na via de sinalização intracelular. Esta via é regulada por uma cascata que envolve três componentes: a MAP quinase (MAPK), a MAP quinase quinase (MAPKK) e a MAP quinase quinase quinase (MAPKKK), através de fosforilações específicas. Assim, a MAPK é ativada por fosforilações catalisadas pela MAPKK, que por sua vez é ativada pela MAPKKK. Uma característica particular que garante que as MAP quinases sejam ativadas 
especificamente é a necessidade de fosforilação dos resíduos de treonina e tirosina separados por um único aminoácido. Quando ativas, as MAP quinases transmitem o sinal pela fosforilação de fatores de transcrição, o qual é essencial para que ocorra a ativação, ou mesmo repressão, de genes que possibilitam uma resposta adaptativa específica (Madhani e Fink, 1998; Xu, 2000; Monge et al., 2006).

Nossos resultados sugerem o envolvimento do gene mak-2 no monitoramento do Pi extracelular, e sua ligação com os outros componentes da via de sinalização para captação de fosfato. Sendo assim, com o objetivo de validar os resultados obtidos por SSH (biblioteca NUC-2 R), e com o intuito de analisar o nível transcricional de mak-2 no monitoramento do Pi extracelular, foram realizados experimentos de Northern blot utilizando RNA total das linhagens selvagem St.L.74A e mutante nuc-2A cultivadas em Pilimitante e Pi-saturante (Figura 12). Pelo fato das MAP quinases fazerem parte de uma família multigênica (Madhani e Fink, 1998; Monge et al., 2006), utilizando a sonda do gene mak-2 observamos uma hibridação cruzada com o gene MAP quinase sty1 (NCU07024).

Os resultados mostraram uma expressão induzida de mak-2 na linhagem mutante nuc-2A independente do Pi extracelular, com um aumento nos níveis de RNAm em relação àquele observado na linhagem selvagem St.L.74A crescida em Pi-limitante. Foi também observado diminuição dos níveis do transcrito mak-2 na linhagem selvagem St.L.74A em resposta à limitação de Pi. Portanto, os resultados demonstram que a expressão do gene mak-2 é regulada negativamente por $n u c-2$, em resposta à limitação do Pi. Desta maneira, com intuito de obter um melhor entendimento da funcionalidade do gene mak-2 no monitoramento do Pi extracelular foi adquirida do FGSC uma linhagem de N. crassa com este gene inativado $\left(m a k-2^{\mathrm{ko}}\right)$. Realizamos experimentos de microarranjos de 
oligonucleotídeos, comparando as linhagens selvagem e mutante $\left(m a k-2^{\mathrm{ko}}\right)$, cultivadas em diferentes concentrações de Pi (Figura 4), possibilitando assim uma melhor compreensão das vias de sinalização intracelular e regulação gênica envolvidas na captação de Pi que permitem aos fungos sobreviverem em condições adversas.

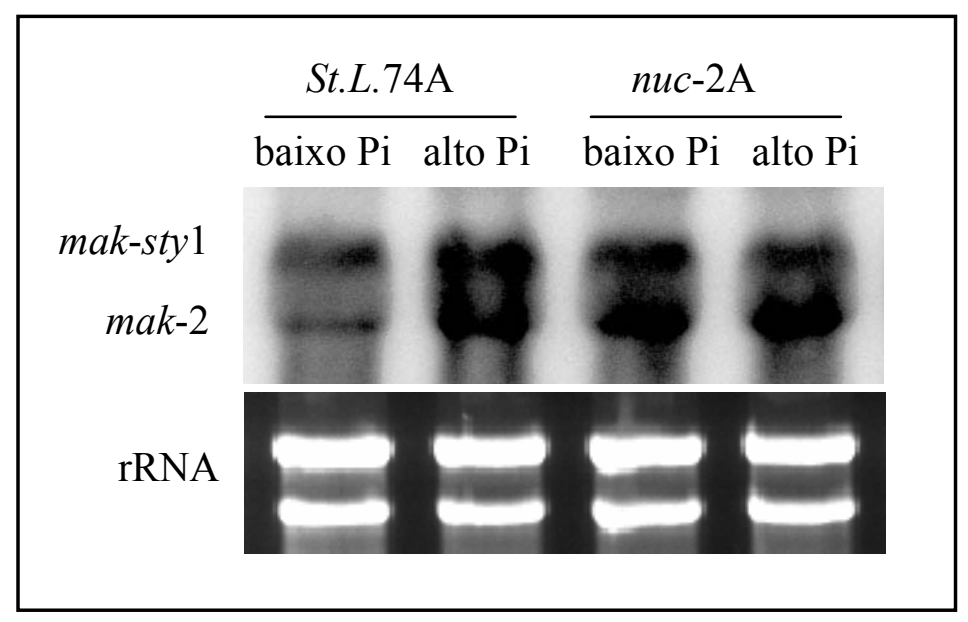

Figura 12. Análise da expressão do gene mak-2 por Northern blot. As bandas de RNA ribossomal foram mostradas para controle da quantidade de RNA colocada em cada poço.

\subsubsection{Avaliação do crescimento da linhagem mutante $m a k-2^{\mathrm{ko}}$}

O efeito da mutação $m a k-2^{\text {ko }}$ no crescimento de $N$. crassa foi avaliado através da comparação da conidiação e produção micelial entre as linhagens selvagem St.L.74A e mutante $m a k-2^{\mathrm{ko}}$. Para isso, as linhagens foram crescidas em meio sólido de Vogel por 72 horas, e posteriormente deixadas à temperatura e luz ambiente por 3 dias para favorecer a conidiação. Após esse período, podemos observar que a linhagem mutante mak-2 $2^{\text {ko }}$ apresentou um fenótipo diferente da linhagem selvagem. Quando cultivada em meio sólido, a linhagem mutante mostrou crescimento reduzido e uma produção abundante de conidióforos com morfologia macroscópica semelhante ao tipo selvagem, mas estes foram produzidos próximo à superfície devido à falta de hifas aéreas normais (Figura 13). Porém, 
a linhagem mutante produziu a mesma quantidade de conídios que a linhagem selvagem St.L.74A.

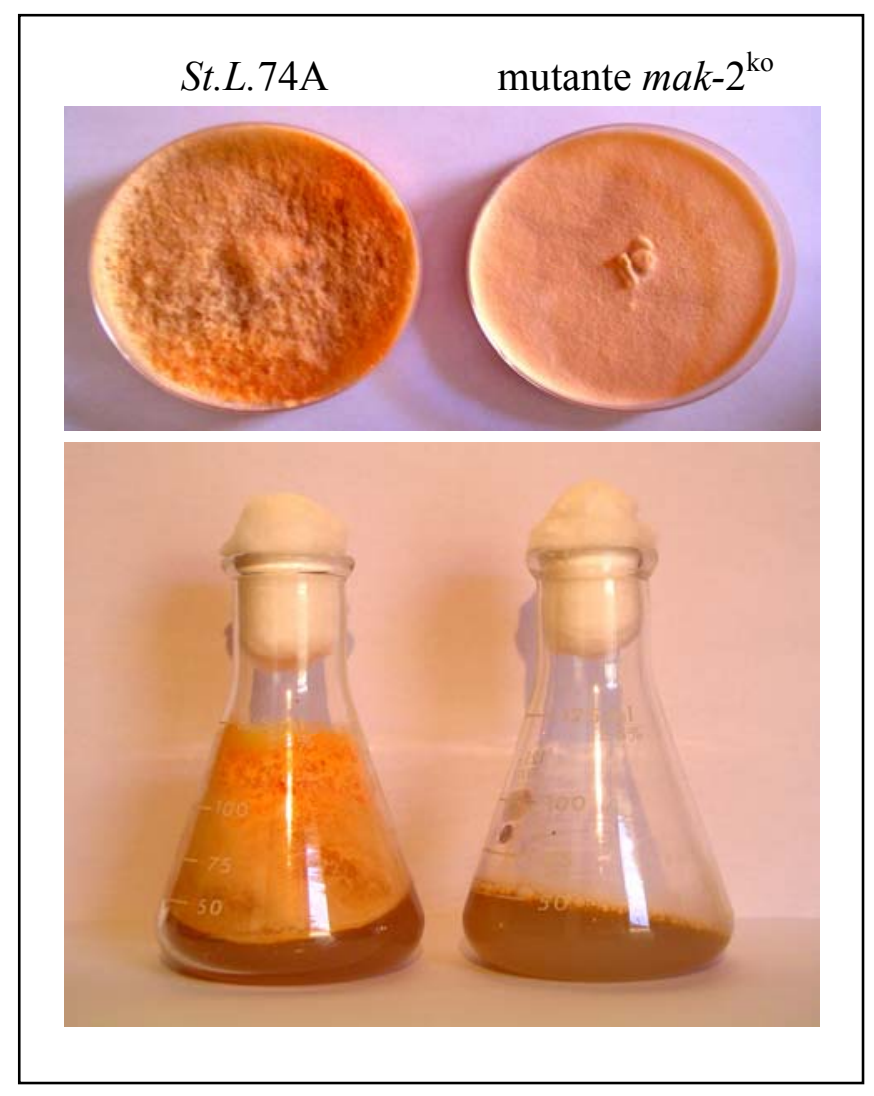

Figura 13. Fenótipos das linhagens selvagem (St.L.74A) e mutante mak-2 ${ }^{\mathrm{ko}}$ de $N$. crassa.

Com o objetivo de comparar o crescimento das linhagens selvagem e mutante conídios foram cultivados por 5 horas em meio líquido de Fries com baixa $(10 \mu \mathrm{M})$ e alta (15mM) concentração de Pi. As linhagens apresentaram diferenças macroscópicas na produção de micélio e na pigmentação. A linhagem selvagem apresentou uma maior massa micelial e coloração laranja mais intensa, enquanto que a linhagem mutante $m a k-2^{\mathrm{ko}}$ apresentou um crescimento menos vigoroso e uma coloração castanha. Por outro lado, os conídios da linhagem mutante apresentam dificuldade de germinação (Figura 14). 


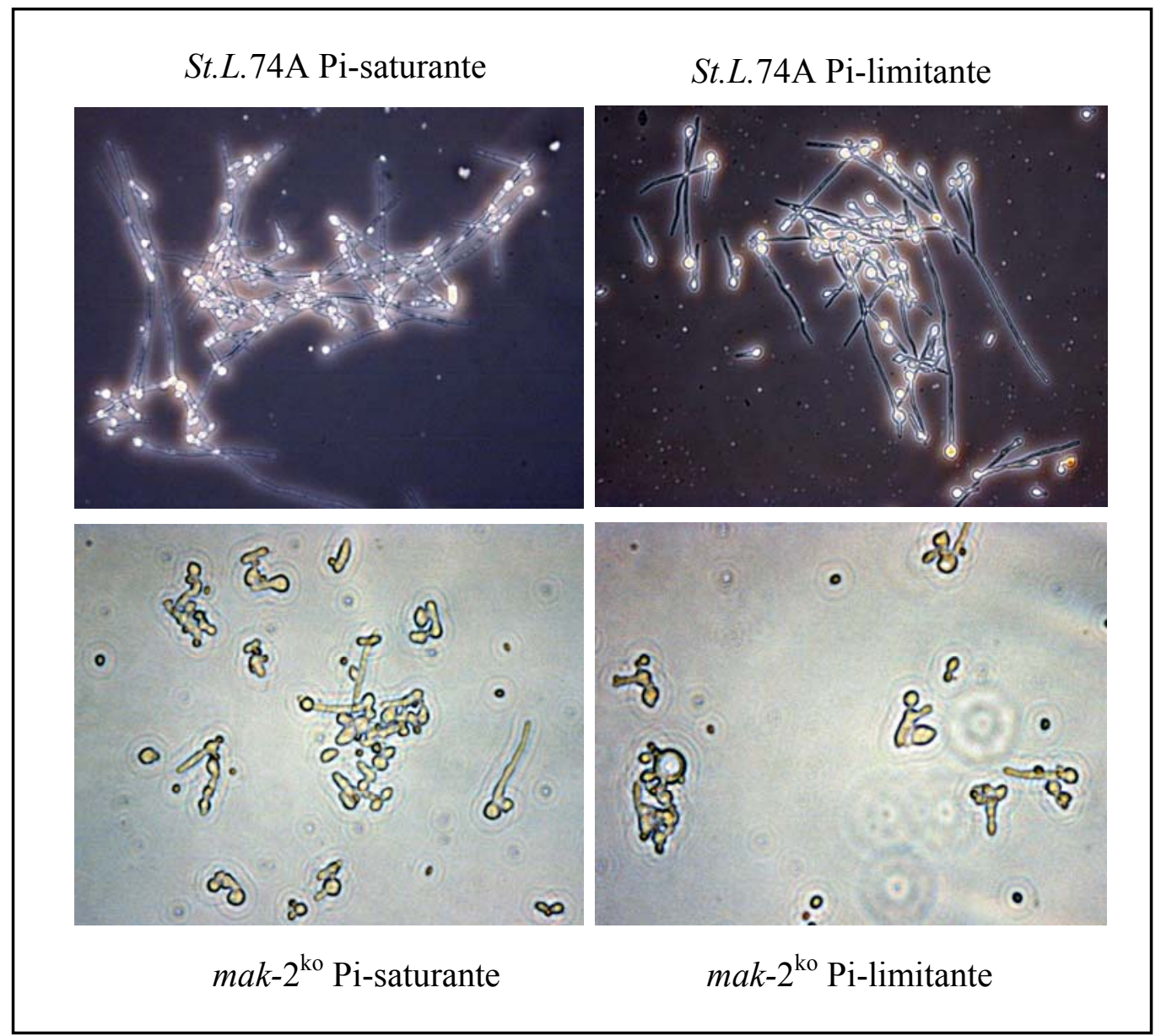

Figura 14. Cultivo das linhagens selvagem (St.L.74A) e mutante $m a k-2^{\mathrm{ko}}$ por 5 horas a $30^{\circ} \mathrm{C}$ em meio liquido de Fries.

\subsubsection{Confirmação da integridade do RNA total pela técnica Agilent (Lab-on-chip)}

Foi definido como critério de qualidade que todas as amostras de RNA utilizadas nos experimentos de microarranjos deveriam apresentar uma razão 260/280 $\geq 1,9$ e, por inspeção visual, as bandas de RNA ribossomal $28 \mathrm{~S}$ e $18 \mathrm{~S}$ deveria apresentar uma razão de intensidade próxima a 2. Das 12 amostras de RNA total obtidas, todas elas apresentaram uma razão 260/280 entre 1,9 e 2,0; e a razão de intensidade das bandas de RNA ribossomal 
28S e $18 \mathrm{~S}$ foi próxima a 2, indicando uma preparação de RNA com ausência de degradação (Figura 15).

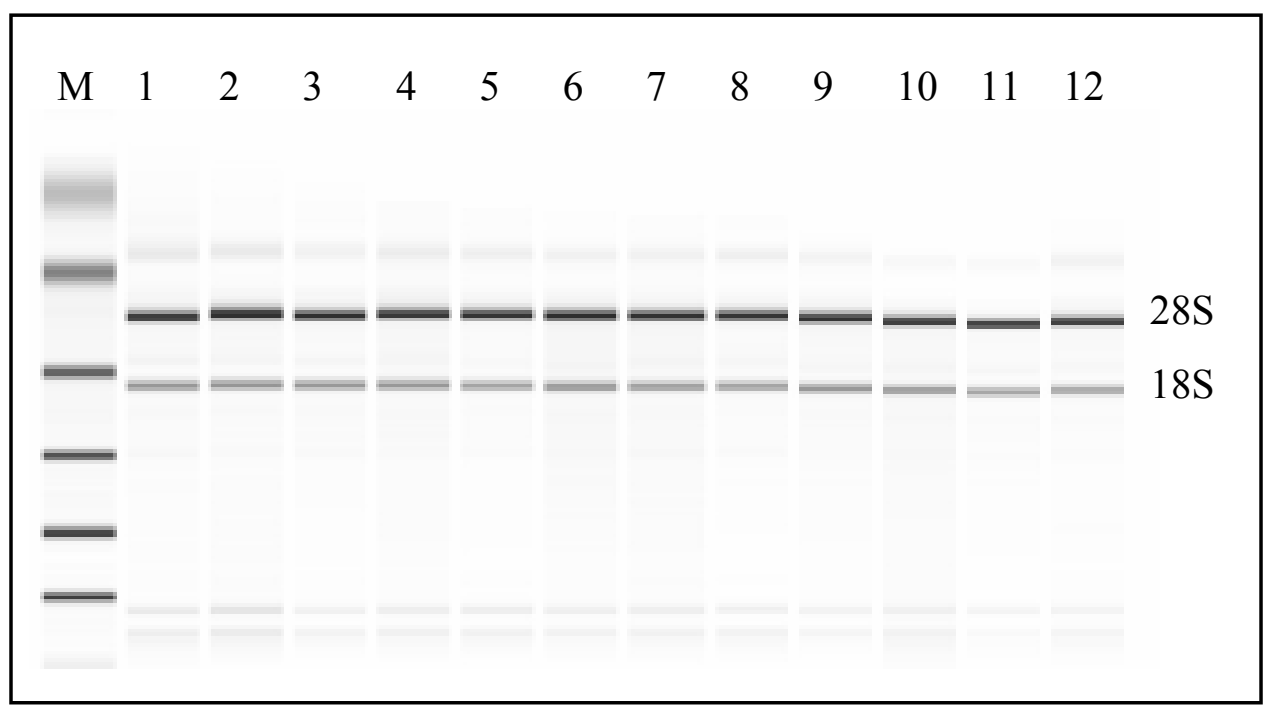

Figura 15. Eletroforese pela tecnologia Agilent mostrando o fracionamento das amostras de RNA total. (1-4) RNA da linhagem St.L.74A cultivada em condições de Pi-limitante; (5-8) RNA da linhagem St.L.74A cultivada em condições de Pi-saturante; (9-12) RNA da linhagem mutante $m a k-2^{\mathrm{ko}}$ cultivada em condições de Pi-limitante. $\mathrm{M}=$ Padrão de massa molecular.

\subsubsection{Hibridação dos microarranjos}

Após hibridação a $42^{\circ} \mathrm{C}$ por 16 horas e todas as etapas de lavagens, os sinais gerados pela hibridação competitiva das duas amostras foram lidos usando o scanner GenePix Pro 6 Microarray Image Analysis. Um resultado típico de uma hibridação está apresentado na Figura 16. 


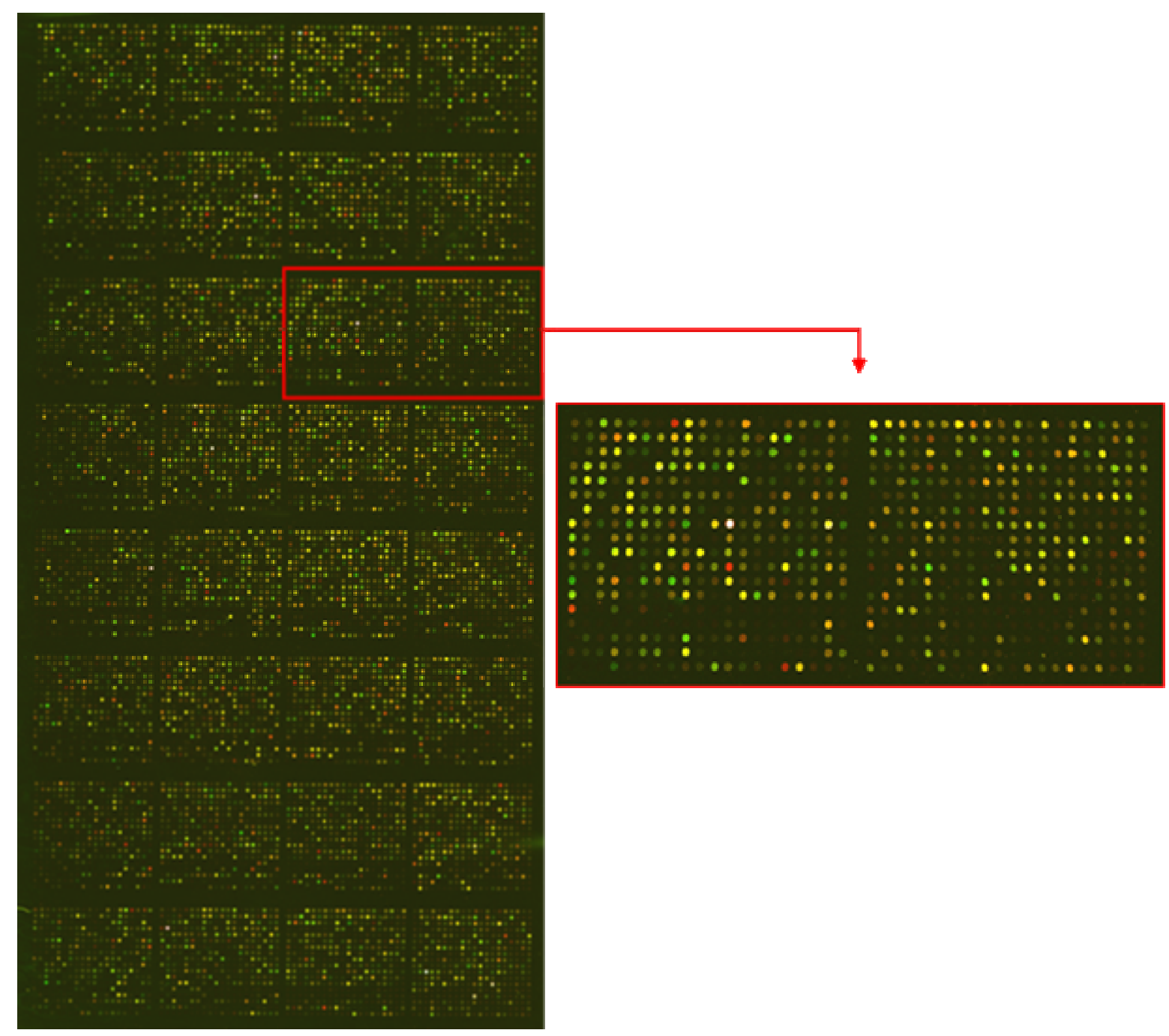

Figura 16. Imagem representativa das hibridações de microarranjos de $N$. crassa. Lâmina onde a linhagem selvagem cultivada com baixa concentração de Pi foi marcada com Cy3 dUTP (verde) e a linhagem selvagem cultivada com alta concentração de Pi foi marcada com Cy5 dUTP (vermelho).

\subsubsection{Avaliação da qualidade das hibridações}

A precisão das medidas de expressão é dada por altos coeficientes de correlação entre as réplicas das diferentes hibridações (inter-lâmina). Foi definido como critério mínimo de qualidade uma correlação inter-lâminas de 0,90. A correlação média entre as réplicas biológicas de cada experimento foi de 0,95 e a média das correlações entre medidas de 
amostras diferentes foi de 0,67 . Somente 4 microarranjos não atingiram os valores de correlação mínimos. Estas réplicas foram re-hibridadas, de modo que todas as amostras possuíssem quatro réplicas, atendendo os critérios de qualidade definidos para este estudo.

As altas correlações médias observadas entre as réplicas foram independentes da condição biológica estudada (linhagem selvagem ou mutante $m a k-2^{\mathrm{ko}}$ ), sendo a correlação média inter-lâmina das amostras igual a 0,954 para a linhagem mutante cultivada em condições de Pi-limitante; e de 0,95 e 0,965 para amostras da linhagem selvagem cultivada em Pi-limitante e saturante, respectivamente. Os altos valores de correlação observados indicam uma elevada reprodutibilidade das medidas de expressão geradas. Essa análise indicou que os dados de expressão gênica das amostras estudadas apresentavam qualidade adequada para as análises subseqüentes. As tabelas 4 e 5 mostram os valores individuais de correlação entre as amostras.

Tabela 4. Matriz de coeficiente de correlação de Pearson das medidas de intensidade de todos os experimentos marcados com Cy5. Em preto, as correlações entre réplicas biológicas, e em cinza, as correlações entre amostras diferentes.

\begin{tabular}{|c|c|c|c|c|c|c|c|c|c|c|c|c|c|c|c|c|}
\hline Cy5 & \multicolumn{4}{|c|}{ WT Baixo Pi } & \multicolumn{4}{|c|}{ WT Alto Pi } & \multicolumn{4}{|c|}{ Mutante Baixo Pi } & \multicolumn{4}{|c|}{ WT Baixo Pi } \\
\hline \multirow{4}{*}{$\begin{array}{c}\text { WT } \\
\text { Baixo Pi }\end{array}$} & 1.00 & & & & & & & & & & & & & & & \\
\hline & 0.90 & 1.00 & & & & & & & & & & & & & & \\
\hline & 0.92 & 0.97 & 1.00 & & & & & & & & & & & & & \\
\hline & 0.93 & 0.91 & 0.93 & 1.00 & & & & & & & & & & & & \\
\hline \multirow{4}{*}{$\begin{array}{l}\text { WT } \\
\text { Alto Pi }\end{array}$} & 0.63 & 0.62 & 0.60 & 0.57 & 1.00 & & & & & & & & & & & \\
\hline & 0.60 & 0.64 & 0.65 & 0.61 & 0.96 & 1.00 & & & & & & & & & & \\
\hline & 0.64 & 0.68 & 0.63 & 0.65 & 0.98 & 0.95 & 1.00 & & & & & & & & & \\
\hline & 0.61 & 0.60 & 0.63 & 0.61 & 0.94 & 0.92 & 0.93 & 1.00 & & & & & & & & \\
\hline \multirow{4}{*}{$\begin{array}{l}\text { Mutante } \\
\text { Baixo Pi }\end{array}$} & 0.65 & 0.60 & 0.60 & 0.62 & 0.83 & 0.81 & 0.85 & 0.79 & 1.00 & & & & & & & \\
\hline & 0.63 & 0.59 & 0.59 & 0.62 & 0.85 & 0.83 & 0.83 & 0.87 & 0.94 & 1.00 & & & & & & \\
\hline & 0.60 & 0.58 & 0.61 & 0.61 & 0.85 & 0.78 & 0.80 & 0.86 & 0.91 & 0.93 & 1.00 & & & & & \\
\hline & 0.61 & 0.60 & 0.62 & 0.61 & 0.82 & 0.80 & 0.78 & 0.81 & 0.92 & 0.95 & 0.96 & 1.00 & & & & \\
\hline \multirow{4}{*}{$\begin{array}{c}\text { WT } \\
\text { Baixo Pi }\end{array}$} & 0.94 & 0.93 & 0.94 & 0.94 & 0.69 & 0.65 & 0.71 & 0.67 & 0.64 & 0.60 & 0.63 & 0.59 & 1.00 & & & \\
\hline & 0.93 & 0.90 & 0.92 & 0.91 & 0.67 & 0.66 & 0.68 & 0.69 & 0.60 & 0.61 & 0.60 & 0.62 & 0.94 & 1.00 & & \\
\hline & 0.92 & 0.95 & 0.95 & 0.90 & 0.65 & 0.68 & 0.62 & 0.70 & 0.61 & 0.60 & 0.61 & 0.63 & 0.93 & 0.90 & 1.00 & \\
\hline & 0.96 & 0.96 & 0.97 & 0.92 & 0.68 & 0.67 & 0.60 & 0.6 & 0.64 & 0.59 & 0.59 & 0.58 & 0.96 & 0.94 & 0.95 & 1.00 \\
\hline
\end{tabular}


Tabela 5. Matriz de coeficiente de correlação de Pearson das medidas de intensidade de todos os experimentos marcados com $\mathrm{Cy} 3$. Em preto, as correlações entre réplicas biológicas, e em cinza, as correlações entre amostras diferentes.

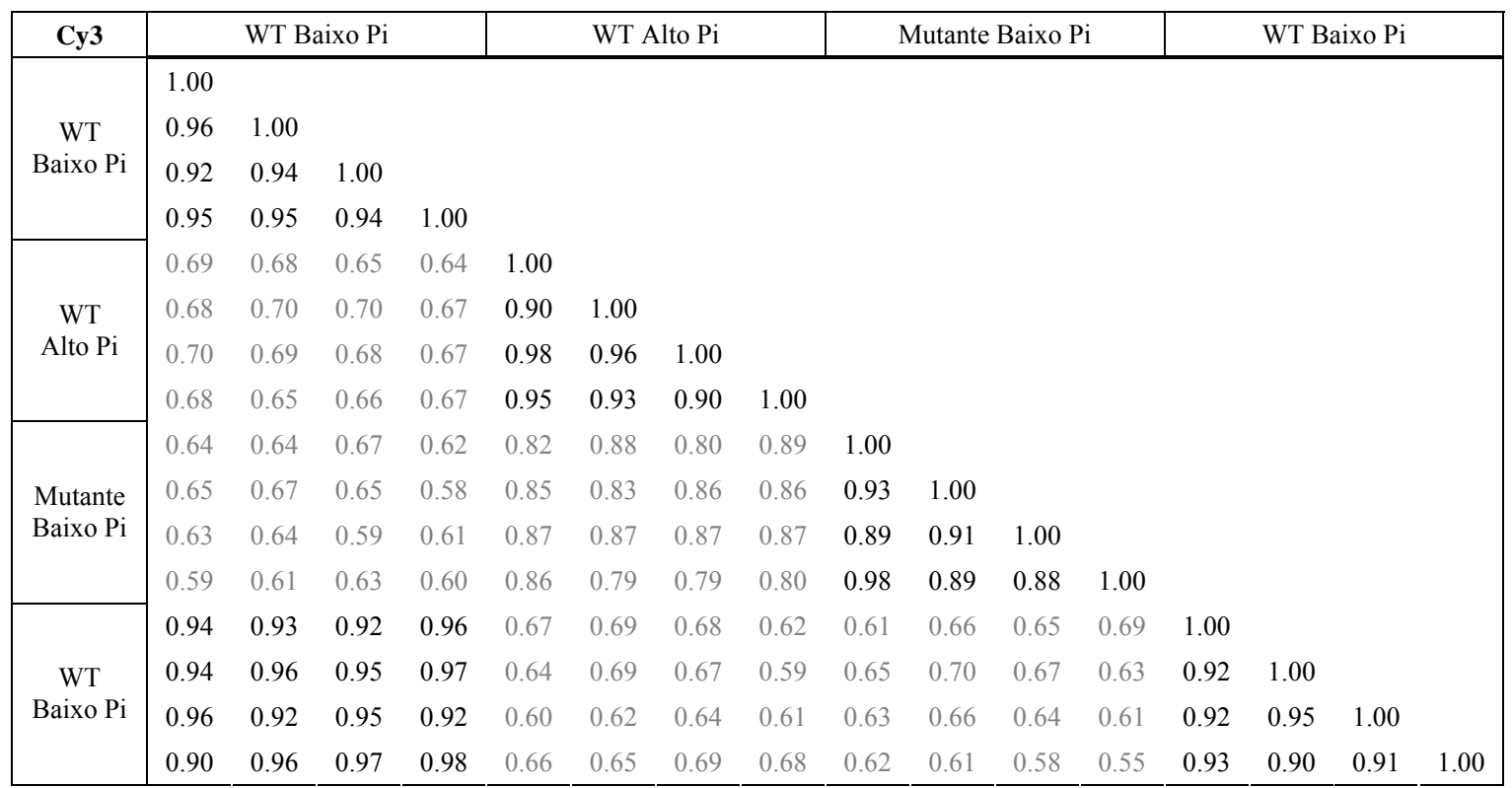

\subsubsection{Identificação de genes diferencialmente expressos}

Os perfis de expressão gênica foram avaliados usando microarranjos de oligonucleotídeos em lâminas de vidro contendo 10.526 sequências alvo as quais foram hibridadas com sondas fluorescentes Cy3 ou Cy5. A caracterização do padrão de expressão gênica foi analisada com o auxílio do programa Significance Analysis of Microarrays (SAM) (Tusher et al., 2001), após as normalizações dos dados através do algoritmo LOWESS. As figuras 17 e 18 mostram os resultados dos transcritos diferencialmente expressos identificados por SAM. Estas figuras representam gráficos de dispersão que ilustram uma comparação entre a distância relativa observada d(i) e a esperada $d_{E}(i)$ dos genes diferencialmente expressos. Os pontos localizados à direita da ordenada e acima de zero são interpretados como genes induzidos (hiperexpressos) em relação à média. Como ultrapassam o limiar $\Delta$ (distância entre as linhas oblíquas tracejadas até a linha oblíqua continua), esses foram considerados diferencialmente expressos pelo programa SAM. Da mesma forma, os pontos à esquerda da ordenada e abaixo do ponto zero, além de serem 
interpretados como genes reprimidos (hipoexpressos) em relação à média, também foram diferencialmente expressos, uma vez que ultrapassam os limites de $\Delta$.

De um total de 10.526 sequências testadas, foram identificados 3.174 transcritos modulados pela concentração de Pi no meio, sendo que 1.525 genes foram induzidos em condições de Pi-limitante, e 1.649 foram reprimidos nesta condição com uma taxa de falso positivo de 5\% (Figura 17). Por outro lado, foram identificados 4.214 transcritos diferencialmente expressos na linhagem mutante $m a k-2^{\mathrm{ko}}$ de $N$. crassa, sendo que 2.306 genes foram hiperexpressos e 1.908 genes hipoexpressos com uma taxa de falso positivo de $5 \%$ (Figura 18).

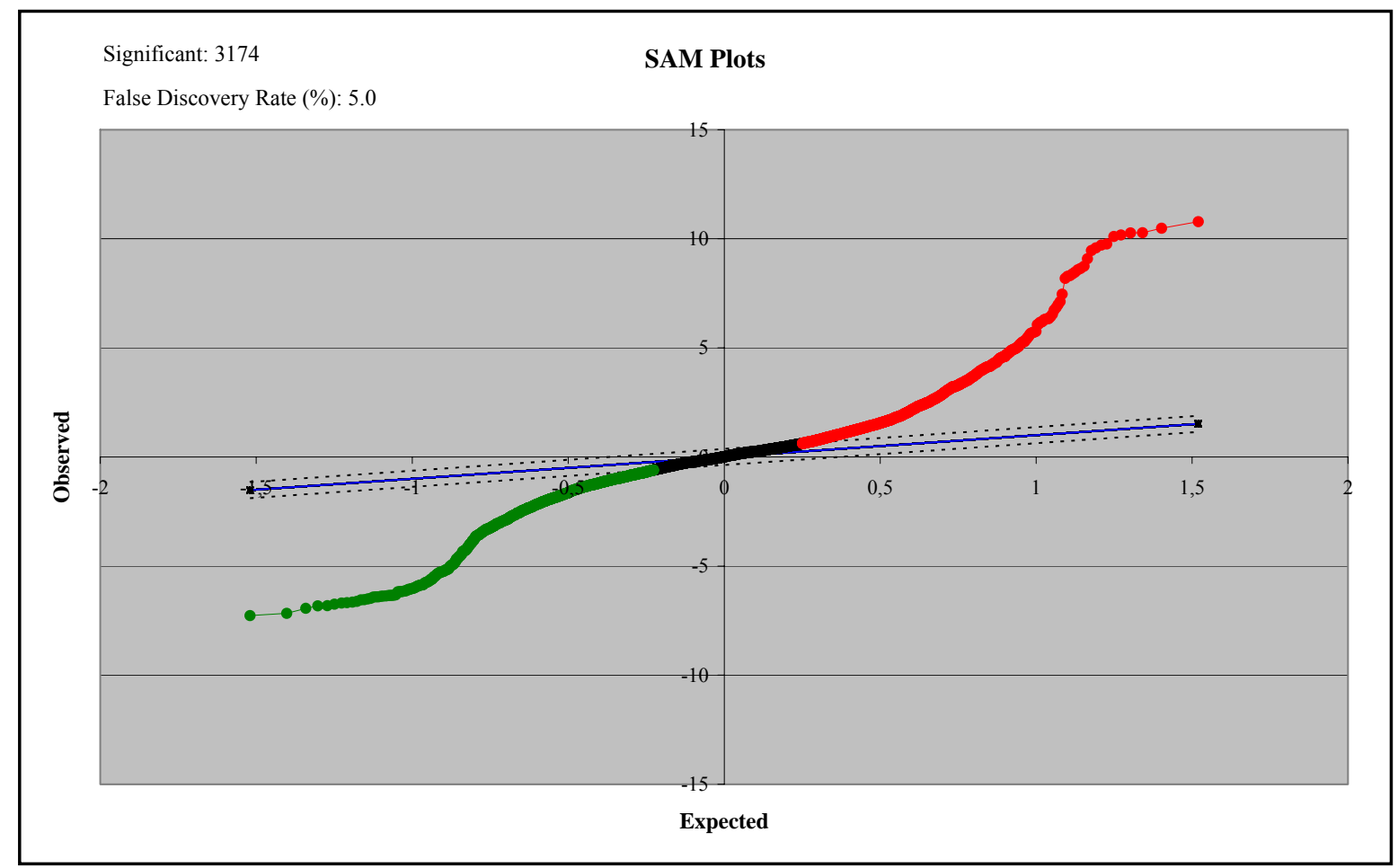

Figura 17. Genes diferencialmente expressos como mostrado pelo programa SAM. Resultados das comparações entre a distância observada d(i) e esperada $d_{E}(i)$ dos dados referentes aos experimentos de microarranjos da linhagem St.L.74A cultivada em condições de Pi-limitante (10 $\mu \mathrm{M})$ ou Pi-saturante $(15 \mathrm{mM})$. A linha azul contínua indica a região onde $\mathrm{d}(\mathrm{i})=\mathrm{d}_{\mathrm{E}}(\mathrm{i})$. As linhas tracejadas são cortes a uma distância $\Delta$ da linha contínua. Os pontos verdes representam genes que se afastam da linha $\mathrm{d}(\mathrm{i})=\mathrm{d}_{\mathrm{E}}(\mathrm{i})$ a uma distância $<\Delta$; já os pontos vermelhos representam genes que se afastam da linha $\mathrm{d}(\mathrm{i})=\mathrm{d}_{\mathrm{E}}(\mathrm{i})$, mas a uma distancia $>\Delta$. 


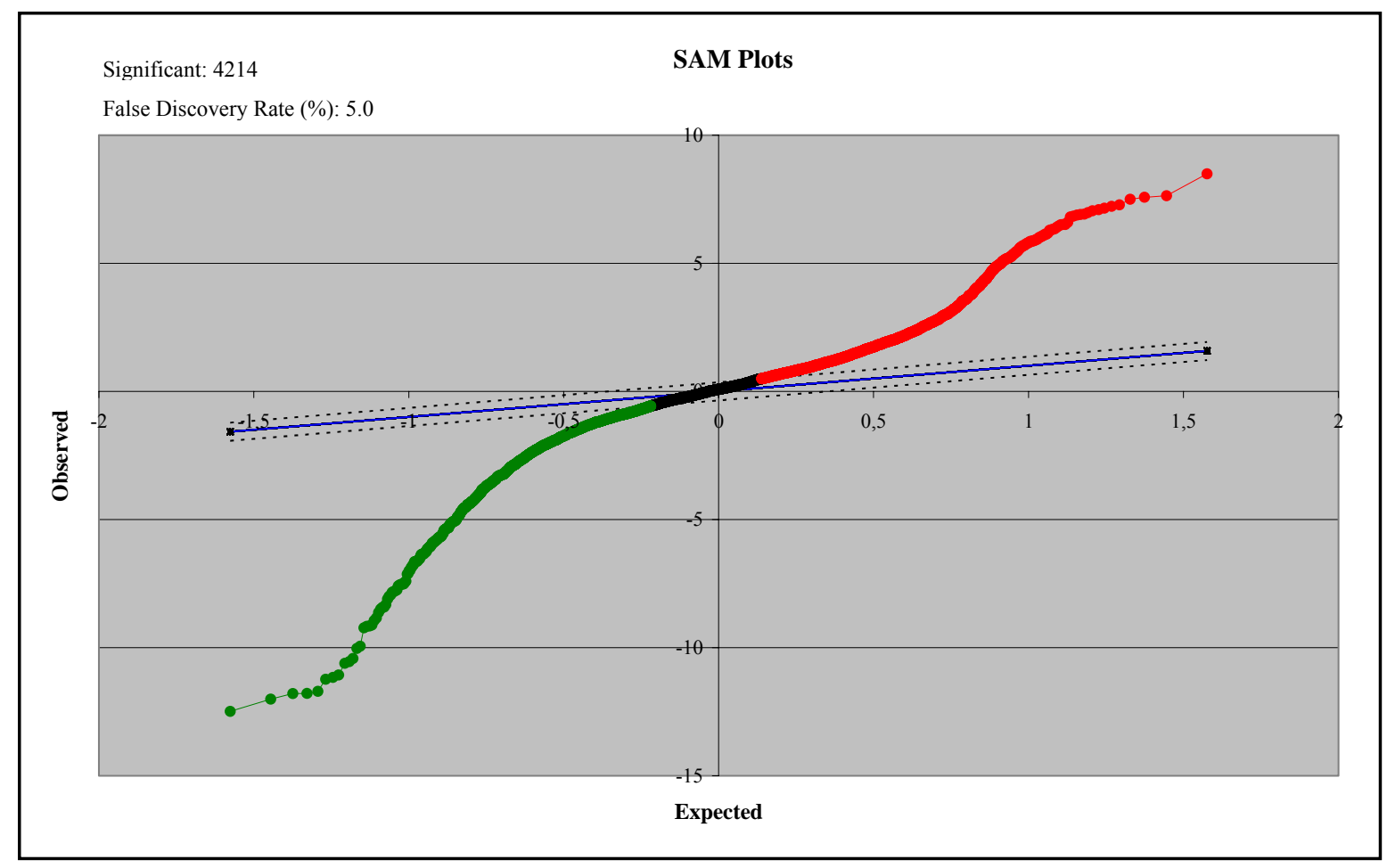

Figura 18. Genes diferencialmente expressos como mostrado pelo programa SAM. Resultados das comparações entre a distância observada d(i) e esperada $d_{E}(i)$ dos dados referentes aos experimentos de microarranjos entre as linhagens selvagem e mutante mak$2^{\mathrm{ko}}$ cultivadas em condições de Pi-limitante $(10 \mu \mathrm{M})$ e $\mathrm{pH}$ ácido $(5,4)$. A linha azul contínua indica a região onde $\mathrm{d}(\mathrm{i})=\mathrm{d}_{\mathrm{E}}(\mathrm{i})$. As linhas tracejadas são cortes a uma distância $\Delta$ da linha contínua. Os pontos verdes representam genes que se afastam da linha $d(i)=d_{E}(i)$ a uma distância $<\Delta$; já os pontos vermelhos representam genes que se afastam da linha d(i) $=\mathrm{d}_{\mathrm{E}}(\mathrm{i})$, mas a uma distancia $>\Delta$.

Vários genes já foram identificados evidenciando seus respectivos papéis durante a resposta adaptativa à disponibilidade de Pi exógeno em $N$. crassa tais como, fosfatases, nucleases e fosfato permeases (Metzenberg, 1979; Kang e Metzenberg, 1993; Peleg et al., 1996a). No presente trabalho, os genes que codificam para a fosfatase alcalina (NCU01376) e a fosfatase ácida (NCU08643) apresentam um aumento nos níveis de expressão em condições de Pi-limitante $(10 \mu \mathrm{M})$ e pH ácido $(5,4)$. 
$N$. crassa e outros organismos monitoram o $\mathrm{pH}$ extracelular para que sejam sintetizadas e secretadas enzimas que efetivamente funcionem no meio externo, como por exemplo, fosfatase ácida em meio ácido e a fosfatase alcalina em meio alcalino (Nahas et al., 1982; Nozawa et al., 2002b). Em N. crassa, a síntese e secreção da fosfatase alcalina Pi-repressível não é reprimida em $\mathrm{pH}$ ácido, porém ocorre uma perda na atividade enzimática dessa enzima nesse $\mathrm{pH}$. Foi visto que a fosfatase alcalina Pi-repressível secretada em $\mathrm{pH}$ alcalino difere daquela secretada em $\mathrm{pH}$ ácido quanto ao nível de glicosilação, sendo que essa última apresenta $13 \%$ de açúcar contra $21 \%$ encontrado na primeira. Esses estudos demonstraram que a síntese de fosfatase alcalina Pi-repressível em N. crassa não depende do pH ambiente, mas determina a glicosilação da enzima secretada (Palma et al., 1989; Han et al., 1994; Nozawa et al., 2003). Portanto, o monitoramento do pH extracelular é determinante na secreção seletiva, mas não na síntese dessa enzima em N. crassa.

Nossos resultados também mostraram que os genes que codificam para os transportadores de fosfato inorgânico PHO84 (NCU08325) e PHO87 (NCU01540), e para a fosfato permease Pi-repressível PHO5 (NCU09564) tiveram expressão induzida em condições de Pi-limitante $(10 \mu \mathrm{M})$ e pH ácido $(5,4)$. O transporte de Pi em $N$. crassa é realizado por dois sistemas metabolicamente regulados pelos níveis de fosfato intracelular. O sistema I apresenta baixa afinidade por Pi e é constitutivo. O sistema II possui alta afinidade por Pi e é reprimido na presença de Pi (Lowendorf e Slayman., 1975; Mann et al., 1989; Versaw, 1995).

A proteína PHO84 de S. cerevisiae, composta por 587 aminoácidos, constitui um dos transportadores de alta afinidade mais caracterizado. A síntese e a atividade desta proteína são positivamente moduladas em condições de Pi-limitante, sendo ativada em 
resposta a concentrações de Pi inferiores a $100 \mu \mathrm{M}$ (Fristedt et al., 1999). PHO84 é responsável pela maior absorção de Pi na célula, enquanto os recentemente caracterizados PHO87, PHO90 e PHO91 parecem desempenhar um papel menos significativo (Giots et al., 2003). A captação de Pi catalisada pelos transportadores de alta afinidade PHO84 e PHO89 apresentam uma forte dependência do pH extracelular. Em pH 5,0 o transportador PHO84 tem atividade ótima, e PHO89 permanece inativo. Em contrapartida, o transportador PHO89 está ativo em meio alcalino com atividade máxima em pH 9,5 (Martinez e Persson, 1998).

Analisamos ainda, o nível de expressão dos genes que codificam as fosfatases ácida e alcalina, PHO84, PHO87 e PHO05 na linhagem mutante mak-2 $2^{\mathrm{ko}}$. Os resultados de microarranjos mostraram que os níveis de expressão desses transcritos estão reduzidos na linhagem mutante $m a k-2^{\mathrm{ko}}$, sugerindo que este gene pode estar regulando positivamente a expressão dos genes envolvidos na captação de $\mathrm{Pi}$, em condições limitantes deste nutriente.

Outro importante transcrito induzido em concentrações de Pi-limitante foi o que codifica o transportador vacuolar (vacuolar transporter chaperone 1 - Vtc1p, NCU03883). Em leveduras, o gene Vtclp é essencial na síntese de polifosfato inorgânico (Poli-P). O Poli-P é uma molécula muito abundante na natureza, sendo encontrada em uma ampla variedade de organismos, desde bactérias a mamíferos. Esta molécula é um polímero linear de dezenas a centenas de resíduos de fosfato ligados por uniões de alta energia (Kornberg et al., 1999). Várias funções biológicas têm sido sugeridas para o Poli-P, incluindo reservatório de energia e de fosfato inorgânico, desintoxicação e canal para a entrada de DNA na célula. Em S. cerevisiae, a biossíntese e o acúmulo de grandes quantidades de Poli-P em condições de Pi-saturante constituem uma estratégia de sobrevivência utilizada frente à carência deste nutriente no meio (Harold, 1966). Porém, Ogawa et al. (2000) 
reportaram que um aumento na capacidade da célula em converter Pi em Poli-P em resposta a limitações de fosfato é necessário para uma ótima aquisição deste nutriente. Uma síntese relativamente baixa de Poli $\mathrm{P}$ em condições de Pi-limitante possivelmente induz um aumento transitório dos níveis de Pi no citosol. Isto pode, por sua vez, conduzir a um feedback negativo sobre a atividade do transportador PHO84. Desta maneira, a síntese de Poli-P desempenha um papel significativo na adaptação das células em condições desfavoráveis do ambiente, promovendo a absorção e o acúmulo de Pi, em longo prazo (Ogawa et. al, 2000; Persson et al., 2003).

De acordo com o modelo proposto para regulação da expressão gênica pelo Pi ambiente em N. crassa, a ação do complexo PREG-PGOV é antagonizada pelo produto do gene nuc-2 (Metzenberg, 1979; Peleg et al., 1996 a,b). Conforme descrito na literatura, e de acordo com nossos experimentos de microarranjos, o gene preg (NCU01738) não é transcricionalmente regulado em função do Pi (Kang e Metzenberg, 1993). Entretanto, este gene teve expressão elevada na linhagem mak-2, como observado nos ensaios de microarranjos, no qual foi comparado o padrão de expressão gênica das linhagens selvagem St.L.74A e mutante mak-2 cultivadas em condições de Pi-limitante. Portanto, os resultados obtidos neste estudo propõem que mak-2 regula negativamente preg, sendo mak-2 regulado negativamente por nuc-2 em função da disponibilidade de fosfato.

Neste trabalho identificamos a regulação de novos genes envolvidos na resposta à disponibilidade de Pi em N. crassa pelo componente NUC-2. Além disto, demonstramos que este componente participa, direta ou indiretamente, na regulação de genes em condições de Pi-saturante. Interessantemente, foi visto que o gene mak-2, que codifica uma importante proteína de sinalização intracelular, é regulado negativamente por nuc-2, e que sua expressão depende da limitação de Pi. Foi observado ainda que o gene mak-2 regula 
negativamente preg. Embora, análises mais detalhadas sejam necessárias para avaliar o papel do gene mak-2, os resultados obtidos sugerem a hipótese de que esse gene constitui um novo e importante componente desta via em N. crassa. Portanto, podemos concluir que ainda existem muitos aspectos a serem descobertos em relação à adaptabilidade de $N$. crassa às oscilações de Pi extracelular, e dos componentes envolvidos neste processo fisiológico. 
CONCLUSÕES 


\section{C O N CLUSÕ E S}

O presente trabalho avaliou a regulação da expressão gênica pelo fosfato no fungo filamentoso Neurospora crassa, contribuindo para uma maior compreensão dos eventos moleculares envolvidos na adaptação à disponibilidade de Pi extracelular. Através de estudos de SSH e microarranjos, os seguintes resultados foram obtidos:

- Novos genes envolvidos na resposta à disponibilidade de Pi em N. crassa, regulados ou não por NUC-2 foram descritos.

- O gene mak-2, que codifica uma proteína de sinalização intracelular, foi encontrado entre os transcritos regulados negativamente por nuc-2, em resposta à limitação de Pi.

- Foi identificado que o gene preg, que codifica uma ciclina envolvida na regulação do fator de transcrição NUC-1, é regulado negativamente por mak-2.

- Outros genes modulados por mak-2, em função da limitação de Pi, também foram identificados.

Portanto, podemos concluir que o gene mak-2 constitui um novo e importante componente da via de sinalização e monitoramento de fosfato em $N$. crassa, regulando preg, e sendo regulado por nuc-2. Este trabalho abre novas perspectivas de estudo para elucidar o papel funcional dos genes identificados, como regulados por nuc-2, mak-2 e/ou disponibilidade de Pi. A possibilidade de se obter linhagens com genes inativados em $N$. crassa, no Fungal Genetics Stock Center, e a realização de experimentos de genômica funcional e análises fenotípicas representam valiosas ferramentas para compreender tanto as respostas adaptativas ao ambiente quanto os circuitos regulatórios que governam a aquisição de fosfato em fungos. 


\section{REFERÊNCIAS BIBLIOGRÁFICAS}




\section{REFERÊ NCIAS B I B L IOG RÁ F I C A S.}

Andrade, M.A; Perez-Iratxeta, C; Ponting, C.P. (2001). Protein Repeats: Structures, Functions and Evolution. J Struct Biol. 134(2-3): 117-131.

Andrade, R.V; Paes, H.C; Nicola, A.M; de Carvalho, M.J; Fachin, A.L; Cardoso, R.S; Silva, S.S; Fernandes, L; Silva, S.P; Donadi, E.A; Sakamoto-Hojo, E.T; Passos, G.A; Soares, C.M; Brígido, M.M, Felipe, M.S. (2006). Cell organisation, sulphur metabolism and ion transport-related genes are differentially expressed in Paracoccidioides brasiliensis mycelium and yeast cells. BMC Genomics. 7: 208.

Andrews, B; Measday, V. (1998). The cyclin family of budding yeast: abundant use of a good idea. Trends Genet. 14(2): 66-72.

Altschul, S.F; Madden, T.L; Schaffer, A.A; Zhang, J; Zhang, Z; Miller, W; Lipman, D.J. (1997). Gapped BLAST and PSI-BLAST: a new generation of protein database search programs. Nucleic Acids Res. 25(17): 3389-3402.

Benne, R; Hershey, J.W. (1976). Purification and characterization of initiation factor IF-E3 from rabbit reticulocytes. Proc Natl Acad Sci USA. 73(9):3005-3009.

Bennett,V; Chen, L.(2001). Ankyrins and cellular targeting of diverse membrane proteins to physiological sites. Curr Opin Cell Biol. 13(1): 61-67.

Browning, K.S; Gallie, D.R; Hershey, J.W; Hinnebusch, A.G; Maitra, U; Merrick, W.C; Norbury , C. (2001). Unified nomenclature for the subunits of eukaryotic initiation factor 3. Trends Biochem Sci. 26(5): 284-285.

Chen, M; Lopes, J.M. (2007). Multiple basic helix-loop-helix proteins regulate expression of the ENO1 gene of Saccharomyces cerevisiae. Eukaryot Cell. 6(5): 786-96.

Crocken, B; Nyc, J.F. (1963). Utilization of L-a-glycerophosphorylcholine by a lecithin-deficient strain of Neurospora crassa. Can J Microbiol. 9: 689-696.

Correa, A; Lewis, Z.A; Greene, A.V; March, I.J; Gomer, R.H; Bell-Pedersen, D; (2003). Multiple oscillators regulate circadian gene expression in Neurospora. Proc Natl Acad Sci USA. 100(23): 13597-13602.

Curach, N.C; Te'o, V.S; Gibbs, M.D; Bergquist, P.L; Nevalainen, K.M. (2004). Isolation, characterization and expression of the hex-1 gene from Trichoderma reesei. Gene. 331:133-140.

Dang, C.V; Lee, W.M. (1989) Nuclear and nucleolar targeting sequences of cerb-A, c-myb, N-myc, p53, HSP70, and HIV tat proteins. J Biol Chem. 264(30): 18019-23.

Davis, R.H. (2000). Neurospora. Contributions of a Model Organism. Oxford University Press, Inc. New York. 319 pp. 
Denison, S.H. (2000). pH Regulation of gene expression in Fungi. Fungal Genet Biol. 29(2): 61-71.

Diatchenko, L; Lau, Y.F; Campbell, A.P; Chenchik, A; Moqadam, F; Huang, B.; Lukyanov, S; Lukyanov, K; Gurskaya, N; Sverdlov, E.D; Siebert, P.D. (1996). Suppression subtractive hybridization: a method for generating differentially regulated or tissue-specific cDNA probes and libraries. Proc Natl Acad Sci USA. 93(12): 6025-6030.

Dilks D.W; Ring R.H; Khawaja X.Z; Novak T.J; Aston, C. (2003). Highthroughput confirmation of differential display PCR results using reverse Northern blotting. J Neurosci Methods. 123(1): 47-54.

Ewing, B; Hillier, L; Wendl, M. C; Green, P. (1998). Base-calling of automated sequencer traces using phred. I. Accuracy assessment. Genom Res. 8(3): 175-85.

Ewing, B; Green, P. (1998). Base-calling of automated sequencer traces using phred. II. Error probabilities. Genome Res. 8(3): 186-94.

Fletcher, T.M; Hansen, J.C. (1996). The nucleosomal array: structure/function relationships. Crit Rev Eukaryot Gene Expr. 6(2-3): 49-188.

Franz, O; Bruchhaus, I; Roeder, T. (1999). Verification of differential gene transcription using virtual Northern blotting. Nucleic Acids Res. 27(11): e3.

Fristedt, U; Weinander, R; Martinsson, H.S; Persson, B.L. (1999). Characterization of purified and unidirectionally reconstituted Pho84 phosphate permease of Saccharomyces cerevisiae. FEBS Lett. 458(1): 1-5.

Furukama, K; Hasunuma, K; Shinohara, Y. (1987). Characterization of Pirepressible enzymes secreted in culture media by Neurospora crassa wild-type cells and null type mutants. J Bacteriol. 169(10): 4790-4795.

Galagan, J.E; Calvo, S.E; Borkovich, K.A; Selker, E.U; Read, N.D; Jaffe, D; FitzHugh, W; Ma, L.J; Smirnov, S; Purcell, S; Rehman, B; Elkins, T; Engels, R; Wang, S; Nielsen, C.B; Butler, J; Endrizzi, M; Qui, D; Ianakiev, P; Bell-Pedersen, D; Nelson, M.A; Werner-Washburne, M; Selitrennikoff, C.P; Kinsey, J.A; Braun, E.L; Zelter, A; Schulte, U; Kothe, G.O; Jedd, G; Mewes, W; Staben, C; Marcotte, E; Greenberg, D; Roy, A; Foley, K; Naylor, J; Stange-Thomann, N; Barrett, R; Gnerre, S; Kamal, M; Kamvysselis, M; Mauceli, E; Bielke, C; Rudd, S; Frishman, D; Krystofova, S; Rasmussen, C; Metzenberg, R.L; Perkins, D.D; Kroken, S; Cogoni, C; Macino, G; Catcheside, D; Li, W; Pratt, R.J; Osmani, S.A; DeSouza, C.P; Glass, L; Orbach, M.J; Berglund, J.A; Voelker, R; Yarden, O; Plamann, M; Seiler, S; Dunlap, J; Radford, A; Aramayo, R; Natvig, D.O; Alex, L.A; Mannhaupt, G; Ebbole, D.J; Freitag, M; Paulsen, I; Sachs, M.S; Lander, E.S; Nusbaum, C; Birren, B. (2003). The genome sequence of the filamentous fungus Neurospora crassa. Nature. 422(6934): 859-868.

Giots, F; Donaton, M.C; Thevelein, J.M. (2003). Inorganic phosphate is sensed by specific phosphate carriers and acts in concert with glucose as a nutrient signal for 
activation of the protein kinase A pathway in the yeast Saccharomyces cerevisiae. Mol Microbiol. 47(4): 1163-1181.

Gorina, S; Pavletich, N.P. (1996). Structure of the p53 tumor suppressor bound to the ankyrin and SH3 domains of 53BP2. Science. 274(5289): 1001-1005.

Gras, D.E; Silveira, H.C.S; Martinez-Rossi, N.M; Rossi, A. (2007). Identification of genes displaying differential expression in the nuc-2 mutant strain of the mold Neurospora crassa grown under phosphate starvation. FEMS Microbiol Lett. 269(2): 196200.

Grotelueschen J; Peleg, Y; Glass, N.L; Metzenberg, R.L. (1994). Cloning and characterization of the pho- $2^{+}$gene encoding a repressible alkaline phosphatase in Neurospora crassa. Gene. 144(1): 147-148.

Guo, B; Chen, X; Dang, P; Scully, B.T; Liang, X; Holbrook, C.C; Yu, J; Culbreath, A.K. (2008). Peanut gene expression profiling in developing seeds at different reproduction stages during Aspergillus parasiticus infection. BMC Dev Biol. 8: 12.

Han, M; Kim, U.J; Kayne, P; Grunstein, M. (1998). Depletion of histone H4 and nucleosomes activates the PHO5 gene in Saccharomyces cerevisiae. EMBO J. 7(7):22212228.

Han, S.W; Michelin, M.A; Barbosa, J.E; Rossi, A. (1994). Purification and constitutive excretion of acid phosphatase in Neurospora crassa. Phytochemistry. 35: 1131-1135.

Harold, F.M. (1966). Inorganic polyphosphates in biology: structure, metabolism, and function. Bacteriol Rev. 30, 772-794.

Hasunuma, K. (1983). Repressible extracellular phosphodiesrerases showing cyclic2',3'and cyclic 3',5' - nucleotide phosphodiesterases activities in Neurospora crassa. J Bacteriol. 156(1): 291-30.

Hinnebusch, A.G. (2006). eIF3: a versatile scaffold for translation initiation complexes. Trends Biochem Sci. 31(10): 553-562.

Horak, C.E; Snyder, M. (2002). Global analysis of gene expression in yeast. Funct Integr Genomics. 2 (4-5): 171-180.

Huang, X; Madan, A. (1999). CAP3: A DNA sequence assembly program. Genome Res. 9(9): 868-877.

Huang, S; Jeffery, D.A; Anthony, M.D; O'Shea, E.K. (2001). Functional analysis of the cyclin-dependent kinase inhibitor Pho81 identifies a novel inhibitory domain. Mol Cell Biol. 21(19): 6695-66705. 
Huang, X; Li, Y; Niu, Q; Zhang, K. (2007) Suppression Subtractive Hybridization (SSH) and its modifications in microbiological research. Appl Microbiol. Biotechnol. 76(4): 753-760.

Jedd, G; Chua, N.H. (2000). A new self-assembled peroxisomal vesicle required for efficient resealing of the plasma membrane. Nat Cell Biol. 2(4): 226-231.

Kang, S; Metzenberg, R.L. (1990). Molecular analysis of $n u c-1^{+}$, a gene controlling phosphorus acquisition in Neurospora crassa. Mol Cell Biol. 10(11): 58395848.

Kang, S; Metzenberg, R.L. (1993). Insertional mutagenesis in Neurospora crassa: cloning and molecular analysis of the preg $^{+}$gene controlling the activity of the transcriptional activator NUC-1. Genetics 133(2): 193-202.

Kasuga, T; Glass, N.L. (2008). Dissecting colony development of Neurospora crassa using mRNA profiling and comparative genomics approaches. Eukaryot Cell. 7(9):1549-1564.

Knight, J.P; Daly, T.M; Bergman, L.W. (2004). Regulation by phosphorylation of Pho81p, a cyclin-dependent kinase inhibitor in Saccharomyces cerevisiae. Curr Genet. 46(1): 10-19.

Kornberg, A; Rao, N.N; Ault-Riché, D. (1999). Inorganic polyphosphate: a molecule of many functions. Annu Rev Biochem. 68: 89-125.

Kozian, D.H; Kirschbaum, B.J. (1999). Comparative gene-expression analysis. Trends Biotechnol. 17(2): 73-78.

Leal, J, Squina, F.M., Martinez-Rossi, N.M; Rossi, A. (2007). The transcription of the gene for iso-orotate decarboxylase (IDCase), an enzyme of the thymidine salvage pathway, is downregulated in the preg $^{\mathrm{C}}$ mutant strain of Neurospora crassa grown under phosphate starvation. Can J Microbiol. 53(8): 1011-1015.

Lehman, J.F; Gleason, M.K; Ahlgren, S.K; Metzenberg, R.L. (1973). Regulation of phosphate metabolism in Neurospora crassa. Characterization of regulatory mutants. Genetics. 75(1): 61-73.

Liang, P; Pardee, A.B. (1992). Differential display of eukaryotic messenger RNA by means of the polymerase chain reaction. Science. 257(5072): 967-971.

Liang, P; Pardee, A.B. (2003). Analysing differential gene expression in cancer. Nat Rev Cancer. 3(11): 869-876.

Liu, C; Yang, Z; Yang, J; Xia, Z; Ao, S. (2000). Regulation of the yeast transcriptional factor PHO2 activity by phosphorylation. J Biol Chem. 275(41): 3197231978. 
Lowendorf, H.S; Slayman, C.W. (1975). Genetic regulation of phosphate transport system II in Neurospora. Biochim Biophys Acta. 413(1): 95-103.

Madhani, H.D; Fink, G.R. (1998). The riddle of MAP kinase signaling specificity. Trends Genet. 14(4): 151-155.

Mann, B.J; Bowman, B.J; Grotelueschen, J; Metzenberg, R.L. (1989). Nucleotide sequence of pho- $4^{+}$, encoding a phosphate-repressible phosphate permease of Neurospora crassa. Gene. 83(2): 281-289.

Maranhão, F.C; Paião, F.G; Martinez-Rossi, N.M. (2007). Isolation of transcripts over-expressed in human pathogen Trichophyton rubrum during growth in keratin. Microb Pathog. 43(4):166-172.

Markham, P; Collinge, A.J. (1987). Woronin bodies in filamentous fungi. FEMS Microbiol. Rev. 46: 1-11.

Martin, K.J; Pardee, A.B. (2000). Identifying expressed genes. Proc Natl Acad Sci USA. 97(8): 3789-3791.

Martinez, P; Persson, B.L. (1998). Identification, cloning and characterization of a derepressible $\mathrm{Na}^{+}$-coupled phosphate transporter in Saccharomyces cerevisiae. Mol Gen Genet. 258(6):628-638.

Maruyama, J; Juvvadi, P.R; Ishi, K; Kitamoto, K. (2005). Three-dimensional image analysis of plugging at the septal pore by Woronin body during hypotonic shock inducing hyphal tip bursting in the filamentous fungus Aspergillus oryzae. Biochem. Biophys Res Commun. 331(4): 1081-1088.

Metzenberg, R.L. (1979). Implications of some genetic control mechanisms in Neurospora. Microbiol Rev. 43(3): 361-383.

Mewes, H.W; Albermann, K; Heumann, K; Liebl, S; Pfeiffer, F. (1997). MIPS: a database for protein sequences, homology data and yeast genome information. Nucleic Acids Res. 25(1): 28-30.

Mewes, H.W; Frishman, D; Güldener, U; Mannhaupt, G; Mayer, K; Mokrejs, M; Morgenstern, B; Münsterkötter, M; Rudd, S, Weil, B. (2002). MIPS: a database for genomes and protein sequences. Nucleic Acids Res. 30(1): 31-34.

Millar, C.B; Grunstein, M. (2006). Genome-wide patterns of histone modifications in yeast. Nat Rev Mol Cell Biol. 7(9): 657-666. 8):1565-1566.

Mohler P.J; Gramolini A.O; Bennett, V. (2002). Ankyrins. J Cell Sci. 115 (Pt

Monge, R.A; Román, E; Nombela, C; Pla. J. (2006). The MAP kinase signal transduction network in Candida albicans. Microbiology. 152: 905-912. 
Morris-Desbois, C; Réty, S; Ferro, M; Garin, J; Jalinot, P. (2001) .HSPC021 interacts with Int-6 and is associated with eukaryotic translation initiation factor 3. J Biol Chem. 276(49):45988-45995.

Mosavi L.K; Cammett T.J; Desrosiers D.C; Peng, Z.Y. (2004). The ankyrin repeat as molecular architecture for protein recognition. Protein Sci. 13(6): 1435-1448.

Mouillon, J.M; Persson, B.L. (2006). New aspects on phosphate sensing and signalling in Saccharomyces cerevisiae. FEMS Yeast Res. 6(2): 171-176.

Nahas, E; Terenzi, H.F; Rossi, A. (1982). Effect of carbon source and pH on the production and secretion of acid phosphatase (EC 3.1.3.2) and alkaline phosphatase (EC 3.1.3.1) in Neurospora crassa. J Gen Microbiol. 128: 2017-2021.

Nozawa, S.R; Thedei Jr. G; Ciacaglini, P; Rossi, A. (2002a). The adaptive response to ambient $\mathrm{pH}$ in Neurospora crassa. Biochemistry and Molecular Biology Education. 30(3): 192-195.

Nozawa, S.R; Thedei Jr, G; Crott, L.S.P; Barbosa, J.E; Rossi, A. (2002b). The synthesis of Pi-repressible alkaline phosphatase do not appear to be regulated by ambient pH in filamentous mould Neurospora crassa. Braz J Microbiol. 33: 92-95.

Nozawa, S.R; May, G.S; Martinez-Rossi, N.M; Ferreira-Nozawa, M.S; CoutinhoNetto, J; Maccheroni, W.Jr; Rossi, A. (2003). Mutation in a calpain-like protease affects the posttranslational mannosylation of phosphatases in Aspergillus nidulans. Fungal Genet. Biol. 38(2): 220-227.

Ogawa, N; DeRisi, J; Brown, P.O. (2000). New components of a system for phosphate accumulation and polyphosphate metabolism in Saccharomyces cerevisiae revealed by genomic expression analysis. Mol Biol Cell. 11(12): 4309-4321.

Oshima, Y. (1991). Impact of the Douglas-Hawthorne model as a paradigm for elucidating cellular regulatory mechanisms in fungi. Genetics. 128(2): 195-201.

Paião, F.G; Segato, F; Cursino-Santos, J.R; Peres, N.T.A; Martinez-Rossi, N.M. (2007). Analysis of Trichophyton rubrum gene expression in response to cytotoxic drugs. FEMS Microbiol Lett. 271(2):180-186.

Palma, M.S; Han, S.W; Rossi, A. (1989). Dissociation and catalytic activity of phosphate-repressible alkaline phosphatase from Neurospora crassa. Phytochemystry. 28: 3281-3284.

Paytan, A; McLaughlin, K. (2007). The oceanic phosphorus cycle. Chem Rev. 107(2): 563-576.

Peleg, Y; Metzenberg, R.L. (1994). Analysis of the DNA-binding and dimerization activities of Neurospora crassa transcription factor NUC-1. Mol Cell Biol.14(12): 7816-7826. 
Peleg, Y; Aramayo, R; Kang, S; Hall, J.G; Metzenberg, R.L. (1996a). NUC-2, a component of the phosphate-regulated signal transduction pathway in Neurospora crassa, is an ankyrin repeat protein. Mol Gen Genet. 252(6): 709-716.

Peleg, Y; Addison, R; Aramayo, R; Metzenberg, R.L. (1996b). Translocation of Neurospora crassa transcription factor NUC-1 into the nucleus is induced by phosphorus limitation. Fungal Genet Biol. 20(3): 185-191.

Pestova, T.V; Kolupaeva, V.G; Lomakin, I.B; Pilipenko, E.V; Shatsky, I.N; Agol, V.I; Hellen, C.U. (2001). Molecular mechanisms of translation initiation in eukaryotes. Proc Natl Acad Sci USA. 98(13):7029-7036.

Persson, B.L; Lagerstedt, J.O; Pratt, J.R; Pattison-Granberg, J; Lundh, K; Shokrollahzadeh, S; Lundh, F. (2003). Regulation of phosphate acquisition in Saccharomyces cerevisiae. Curr Genet. 43(4):225-244

Quackenbush, J. (2002). Microarray data normalization and transformation. Nat Genet. 32 Suppl: 496-501.

Rubtsov, A.M; Lopina, O.D. (2000). Ankyrins. FEBS Lett. 482(1-2): 1-5.

Ruepp, A; Zollner, A; Maier, D; Albermann, K; Hani, J; Mokrejs, M; Tetko, I; Güldener, U; Mannhaupt, G; Münsterkötter, M; Mewes, HW. (2006). The FunCat, a functional annotation scheme for systematic classification of protein from whole genomes. Nucleotic Acids Res. 32(18): 5539-5545.

Sakamoto-Hojo, E.T; Mello, S.S; Cardoso, R.S; Passos, G.A.S (2003). Utilização de genômica funcional e proteômica em mutagêneses (Cap. 12). Mutagênese Ambiental. Ed. ULBRA. 356 pp.

Sambrook, J; Fritsch, E.F; Maniatis, T. (1989) Molecular Cloning. A Laboratory Manual. New York: Cold Spring Harbor Laboratory Press. 754 pp.

Schena, M; Shalon, D; Davis, R.W; Brown, P.O. (1995). Quantitative monitoring of gene expression patterns with a complementary DNA microarray. Science. 270(5235): 467-470.

Sedgwick, S.G; Smerdon, S.J. (1999). The ankyrin repeat: a diversity of interactions on a common structural framework. Trends Biochem Sci. 24(8): 311-316.

Segato, F; Nozawa, S.R; Rossi, A; Martinez-Rossi, N.M. (2008). Over-expression of genes coding for proline oxidase, riboflavin kinase, cytochrome c oxidase and an MFS transporter induced by acriflavin in Trichophyton rubrum. Med Mycol. 46(2):135-139.

Silva, E.M; Freitas, J.S; Gras, D.E; Squina, F.M; Leal, J; Silveira, H.C.S; Martinez-Rossi, N.M; Rossi, A. (2008). Identification of genes differentially expressed in a strain of the mold Aspergillus nidulans carrying a loss-of-function mutation in the palA gene. Can J Microbiol. 54(10): 803-811. 
Silveira, H.C.S. (2007). A capacidade de infecção do dermatófito Trichophyton rubrum está correlacionada com a sinalização do pH extracelular. Tese de Doutorado em Genética. Faculdade de Medicina de Ribeirão Preto. Universidade de São Paulo. 121 pp.

Soares, M.B. (1997). Identification and cloning of differentially expressed genes. Curr Opin Biotechnol. 8(5): 542-546.

Soundararajan, S; Jedd, G; Li, X; Ramos-Pamploña, M; Chua, N.H; Naqvi, N.I. (2004). Woronin body function in Magnaporthe grisea is essential for efficient pathogenesis and for survival during nitrogen starvation stress. Plant Cell. 16(6): 15641574.

Tenney, K; Hunt, I; Sweigard, J; Pounder, J.I; McClain, C; Bowman E.J; Bowman, B.J. (2000). Hex-1, a gene unique to filamentous fungi, encodes the major protein of the Woronin body and functions as a plug for septal pores. Fungal Genet. Biol. 31(3):205-217.

Tey, W.K; North, A.J; Reyes, J.L; Lu, Y.F; Jedd, G. (2005). Polarized gene expression determines Woronin body formation at the leading edge of the fungal colony. Mol Biol Cell.16(6): 2651-2659.

Tusher, V.G; Tibshirani, R; Chu, G. (2001). Significance analysis of microarrays applied to the ionizing radiation response. Proc Natl Acad Sci USA. 98(9): 5116-5121.

Velculescu, V.E; Zhang, L; Vogelstein, B; Kinzler, K.W. (1995). Serial analysis of gene expression. Science. 270(5235): 484-487.

Versaw, W.K. (1995). A phosphate-repressible, high-affinity phosphate permease is encoded by the pho- $5^{+}$gene of Neurospora crassa. Gene. 153(1): 135-139.

Vogel, H.J. (1956). A convenient growth medium for Neurospora crassa. Microbial Genet Bull. 13: 42-43.

Waters, N.C; Knight, J.P; Creasy, C.L; Bergman, L.W. (2004). The yeast Pho80Pho85 cyclin-CDK complex has multiple substrates. Curr Genet. 46(1): 1-9.

Wolffe, A.P; Hayes, J.J. (1999). Chromatin disruption and modification. Nucleic Acids Res. 27(3): 711-720.

Wyrick, J.J; Holstege, F.C; Jennings, E.G; Causton, H.C; Shore, D; Grunstein, M; Lander, E.S; Young, R.A. (1999). Chromosomal landscape of nucleosome-dependent gene expression and silencing in yeast. Nature. 402(6760):418-421

Wu, D; Dou, X; Hashmi, S.B; Osmani, S.A. (2004). The Pho80-like cyclin of Aspergillus nidulans regulated development independently of its role in phosphate acquisition. J Biol Chem. 279(36): 37693-37703. 

152.

Xu, J.R. (2000). Map kinases in fungal pathogens. Fungal Genet Biol. 31(3): 137-

Zhou, C; Arslan, F; Wee, S; Krishnan, S; Ivanov, A.R; Oliva, A; Leatherwood, J; Wolf, D.A. (2005). PCI proteins eIF3e and eIF3m define distinct translation initiation factor 3 complexes. BMC Biol. 3:14. 


\title{
Identification of genes displaying differential expression in the nuc-2 mutant strain of the mold Neurospora crassa grown under phosphate starvation
}

\author{
Diana E. Gras ${ }^{1}$, Henrique C.S. Silveira ${ }^{1}$, Nilce M. Martinez-Rossi ${ }^{1}$ \& Antonio Rossi ${ }^{2}$ \\ ${ }^{1}$ Departamento de Genética, Faculdade de Medicina de Ribeirão Preto, Universidade de São Paulo, Brazil; and ²Departamento de Bioquímica e \\ Imunologia, Faculdade de Medicina de Ribeirão Preto, Universidade de São Paulo, Brazil
}

\begin{abstract}
Correspondence: Antonio Rossi, Departamento de Bioquímica e Imunologia, Faculdade de Medicina Ribeirão Preto, Universidade de São Paulo, Av Bandeirantes 3900, Ribeirão Preto 14049-900, Brazil. Tel.: +55163602 3112; fax:+55163633 6840; e-mail: anrossi@usp.br
\end{abstract}

Received 2 November 2006; revised 7 December 2006; accepted 11 December 2006. First published online 11 January 2007.

DOI:10.1111/j.1574-6968.2006.00613.x

Editor: Michel Jacquet

\section{Keywords}

Neurospora crassa; ankyrin repeat; nuc-2

gene; Pi regulation; elF3; translational control.

\begin{abstract}
Subtractive hybridization was used to isolate transcripts up-regulated in the $n u c-2$ mutant strain of Neurospora crassa grown under phosphate starvation. Following differential screening, $66 \mathrm{cDNA}$ clones of the total enriched were screened in a second round by reverse Northern hybridization. The 17 cDNA candidates displaying visual positive differential expression were sequenced, and functional grouping identified putative proteins possibly involved in diverse cellular processes as, for example, protein synthesis, signal transduction mechanisms, and transport facilitation. Four of them, confirmed by both virtual and Northern blot analyses, revealed genes involved in the initiation of mRNA translation that are significantly up-regulated in the nuc-2 mutant strain, which may be relevant to a further understanding of the molecular events involved in the phosphorus sensing in N. crassa.
\end{abstract}

\section{Introduction}

Inorganic phosphate $(\mathrm{Pi})$ is an essential growth-limiting nutrient in nature, required for the biosynthesis of nucleic acids and many other phosphorylated metabolites, including those involved in energy transduction and metabolic signaling responses. All living organisms have evolved complex signal transduction networks that enable them to sense the availability of nutrients and modulate metabolic activities for their acquisition. The filamentous mold Neurospora crassa synthesizes a number of Pi-repressible phosphatases and permeases that have the function of making more Pi available to the cell, i.e., these enzymes are synthesized and secreted in response to the signaling of phosphorus starvation (Metzenberg, 1979; Han \& Rossi, 1989). The genetic and molecular mechanisms controlling this response in $N$. crassa include four regulatory genes, nuc-2, preg, pgov, and $n u c-1$, involved in a hierarchical relationship (Metzenberg, 1979). The availability of $\mathrm{Pi}$ is sensed by the nuc-2 gene, whose transcription is regulated in response to the levels of Pi (Peleg et al., 1996a). The NUC-2 protein transmits the metabolic signal downstream the regulatory pathway, inhibiting the functioning of the PREG-PGOV complex under limiting $\mathrm{Pi}$, which allows the activation of the wide domain transcription regulator NUC-1, i.e., its translocation into the nucleus (Kang \& Metzenberg, 1990, 1993; Peleg et al., 1996b). NUC-2 is an ankyrin-like repeat protein that carries one of the most common protein sequence motifs (Peleg et al., 1996a). The ankyrin repeat proteins have been detected in organisms ranging from viruses to humans and constitute a class of proteins that regulate, for example, important biological functions of the cell cycle and of the cytoskeleton organization (Michaely \& Bennett, 1992; Cai \& Zhang, 2006). The NUC-2, PREG, PGOV, and NUC-1 proteins have homology, respectively, to PHO81, PHO80, PHO85, and PHO4 from Saccharomyces cereviseae. $\mathrm{PHO} 80$ and $\mathrm{PHO} 85$ form a cyclin-CDK complex, which phosphorylates PHO4 (Knight et al., 2004; Waters et al., 2004).

In an attempt to identify genes involved in metabolic responses to exogenous Pi sensing, a suppression subtractive hybridization (SSH) was used between RNA isolated from the wild type and $n u c-2$ mutant strains of $N$. crassa grown under Pi starvation, $\mathrm{pH}$ 5.4. This study revealed genes involved in the initiation of mRNA translation that are significantly up-regulated in the $n u c-2$ mutant strain, which 
may be relevant to a further understanding of the functioning of gene $n u c-2$ in N. crassa.

\section{Materials and methods}

\section{Strains, culture conditions, and cDNA synthesis}

The strains St.L.74A (wild type) and the nuc-2A mutant (FGSC\#1996) of N. crassa were obtained from the Fungal Genetic Stock Center, School of Biological Sciences, University of Missouri, Kansas City, Missouri, and maintained on slants of Vogel's (1956) medium (1.5\% agar). The nuc-2 mutation was induced in the St.L. 74A strain by UV light, and the mutant strain was selected for its inability to utilize RNA or DNA as its sole phosphorus source (Ishikawa et al., 1969; Peleg et al., 1996a).

Conidia from each strain (about $10^{6}$ cells $\mathrm{mL}^{-1}$ ) were grown for $5 \mathrm{~h}$ at $30^{\circ} \mathrm{C}$, in an orbital shaker $(200 \mathrm{rpm})$, in both low- and high-Pi medium (respectively, $10 \mu \mathrm{M}$ or $15 \mathrm{mM} \mathrm{Pi}$, final concentrations) adjusted to $\mathrm{pH} 5.4$ (buffered with $50 \mathrm{mM}$ sodium citrate), supplemented with $44 \mathrm{mM}$ sucrose as the carbon source, and prepared as previously described (Nyc et al., 1966; Rodrigues \& Rossi, 1985). One microgram of total RNA, extracted from mycelia with the NucleoSpin ${ }^{\circledR}$ RNA Plant Kit (BD Biosciences Clontech, Palo Alto, CA), was used for the synthesis of double-stranded cDNAs with the BD SMART ${ }^{\mathrm{TM}}$ PCR cDNA Synthesis Kit (BD Biosciences Clontech, Palo Alto, CA). The manufacturer's recommendations were used throughout the cDNA synthesis procedure.

\section{SSH and screening of subtracted cDNA clones}

The SSH (Diatchenko et al., 1996) was performed between the driver and the tester cDNAs obtained, respectively, from mycelium of the wild type and nuc-2 mutant strains, using the Clontech PCR-Select ${ }^{\mathrm{TM}}$ cDNA Subtraction Kit as recommended (BD Biosciences Clontech, Palo Alto). The PCR product of subtraction was cloned into pGEM-T Easy Vector Systems (Promega), and the plasmids were transformed into competent cells of Escherichia coli grown on Luria-Bertani (LB)-agar medium supplemented with ampicillin $\left(50 \mu \mathrm{g} \mathrm{mL}^{-1}\right)$ under $\mathrm{X}$-gal and isopropyl- $\beta$-D-thiogalactopyranoside (IPTG) selection. The white colonies of E. coli containing individual inserts of the differentially expressed sequences in the tester population were picked up, grown in ampicillin-LB medium for $12 \mathrm{~h}$ at $37^{\circ} \mathrm{C}$, and amplified by PCR using the nested primers 1 and $2 \mathrm{R}$ from the SSH kit and $2 \mu \mathrm{L}$ of the E. coli culture as a template. Cycling was as follows: $94^{\circ} \mathrm{C}$ for $2 \mathrm{~min}$, and then 30 cycles of $95^{\circ} \mathrm{C}$ for $30 \mathrm{~s}, 65^{\circ} \mathrm{C}$ for $30 \mathrm{~s}$, and $72{ }^{\circ} \mathrm{C}$ for $1.5 \mathrm{~min}$. After checking in a $2 \%$ agarose gel, the rest of the PCR products were denatured with equal amounts of $0.6 \mathrm{~N} \mathrm{NaOH}$ and used for differential screening. Four microliter of this mixture, for each clone, was blotted in duplicate onto nylon membranes (Hybond-N+, Amersham Pharmacia Biotech) using a vacuum blotter. To bypass the loss of low-abundance-expressed sequences, the subtracted library was hybridized with both forward- and reverse-subtrated cDNA probes, which were labeled with fluorescein using the Gene Images Random Prime Labelling Module (Amersham Biosciences). Hybridizations were performed overnight at $60^{\circ} \mathrm{C}$ under continuous agitation, the membranes washed as recommended (Amersham Biosciences), and then exposed to an X-ray film (Kodak Biomax MR film).

\section{DNA sequencing and analysis}

The plasmid from arrayed clones showing visual positive differential expression was purified and sequenced using the M13 Forward primer. Sequencing reactions were performed with the ABI Prism ${ }^{\circledR}$ BigDye Terminator Cycle Sequencing Kit and analyzed using the ABI Prism ${ }^{\circledR} 377$ DNA Sequencer (Applied Biosystems, Foster City, CA). The expressed sequence tag (EST) sequences showing high nucleotide quality were processed using the software CAP3 for contig assembly, and the corresponding ORFs were identified in the N. crassa Genome database (Galagan et al., 2003) (http://www. broad.mit.edu/annotation/genome/neurospora/Home.html), and subjected to BLASTN and BLASTX search against GenBank database (Altschul et al., 1997). The sequences were grouped into functional categories (Munich Information Center for Protein Sequences) (http://mips.gsf.de) according to their putative BLASTX identification (Mewes et al., 1997, 2002)

\section{Northern analysis}

To perform virtual Northern blots (Franz et al., 1999), the driver and the tester population of cDNAs generated by the SMART procedure were electrophoresed in a $1.2 \%$ agarose gel, denatured, and blotted ( $3 \mu \mathrm{g})$ onto Hybond-N+nylon membranes (Amersham Biosciences). Subtracted clones were amplified by PCR, purified with the GFX PCR DNA and Gel Band purification kit, and used as probes labeled with fluorescein using the Gene Images Random Prime Labelling Module (Amersham Biosciences). The $\beta$-tubulin gene $(B m l R)$ obtained from the Fungal Genetic Stock Center (plasmid pBT6) was used as the control. Hybridizations were performed overnight at $60^{\circ} \mathrm{C}$ under continuous agitation, the membranes washed as recommended (Amersham Biosciences), and then exposed to an X-ray film (Kodak Biomax MR film).

For validation of differential gene expression by Northern blot, the strains wild type and nuc-2 were cultivated as described for the construction of the subtractive suppressive cDNA library. The total RNA from each strain was extracted with TRIzol ${ }^{\circledR}$ reagent (Invitrogen), and c. $15 \mu \mathrm{g}$ was 

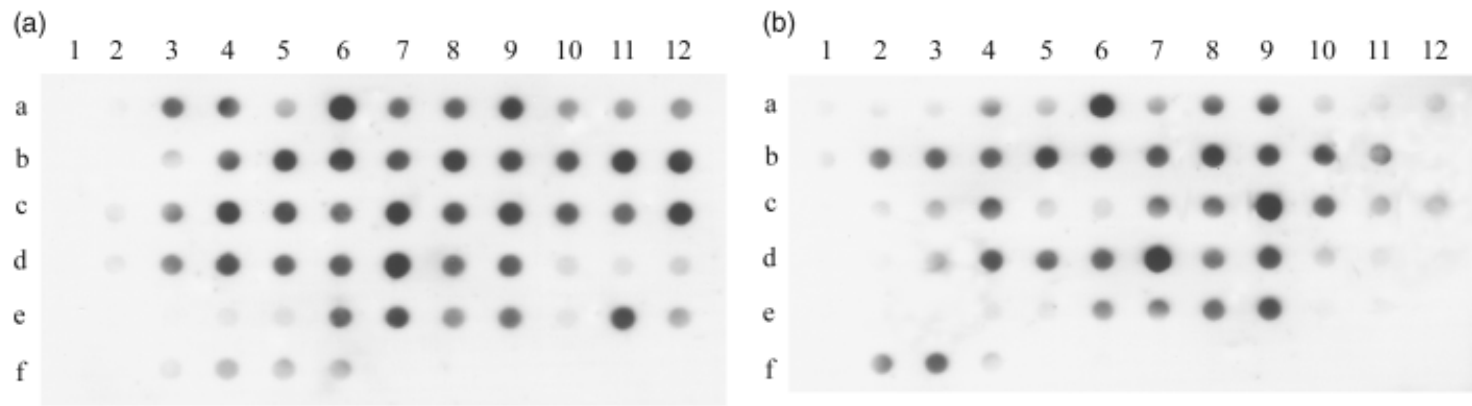

Fig. 1. Comparison of differential screening of subtracted cDNAs from Neurospora crassa nuc-2A mutant and wild type strains. Equal amounts of amplified cDNAs were arrayed onto two membranes and hybridized with two different probes. (a) Blot hybridized with forward (nuc-2A mutant strain) subtracted cDNA probe. (b) Blot hybridized with reverse (wild type strain) subtracted CDNA probe.

Table 1. Genes with elevated expression in nuc-2A mutant screened by reverse Northern hybridization

\begin{tabular}{lll}
\hline EST* $^{*}$ & Predicted ORF $^{\dagger}$ & Putative gene products/MIPS functional category \\
\hline A3 & NCU02571.3 & Acetyl-CoA acetyltransferase/Amino acid metabolism \\
A4 & NCU08964.3 & Probable 60S ribosomal protein L10, cytosolic/Protein synthesis \\
A7/F6 & NCU04553.3 & Ubiquitin-40Sribosomal protein S27a fusion protein/Protein fate \\
A9 & NCU07857.3 & 60S ribosomal protein L34/Protein synthesis \\
A10 & NCU08389.3 & 60S ribosomal protein L20/Protein synthesis \\
A11 & NCU00957.3 & Related to extracellular matrix protein precursor/Biogenesis of cellular components \\
A12 & NCU09477.3 & ADP, ATP Carrier protein (ADP/ATP translocase)/Cellular transport, transport facilitation and transport routes \\
C3 & NCU04736.3 & Hypothetical protein similar to P-type calcium ATPase/Cellular transport, transport facilitation and transport routes \\
C4 & NCU08620.3 & 40S ribosomal protein S16/Protein synthesis \\
C5 & NCU02393.3 & Mitogen-activated kinase-2/Signal transduction mechanism \\
C6 & NCU03038.3 & 40S ribosomal protein S13/Protein synthesis \\
C7 & NCU02003.3 & Elongation factor-1 alpha/Protein synthesis \\
C8 & NCU00413.3 & 60S ribosomal protein L2/Protein synthesis \\
C12 & NCU03806.3 & 60S ribosomal protein L28 (L27A)/Protein synthesis \\
D3 & NCU07380.3 & Eukaryotic translation initiation factor 3d (elF3d)/Cell cycle and DNA processing \\
E6 & NCU02853.3 & Unclassified/Hypothetical protein \\
\hline
\end{tabular}

*The identification and differential screening of the clones are shown in Fig. 1.

${ }^{\dagger}$ Genes names in database (Broad Institute).

electrophoresed on $1 \%$ agarose gel containing formaldehyde, transferred onto a Hybond-N+membrane, and hybridized with subtracted clones amplified by PCR radioactively labeled with $\left[\alpha_{-}{ }^{32} \mathrm{P}\right]-\mathrm{dCTP}$, as described previously (Sambrook et al., 1989).

\section{Results and discussion}

SSH constructed to isolate transcripts specific to or upregulated in the $n u c-2 A$ mutant strain generated a population of 362 cDNA clones. Following differential screening of these clones using both the forward-and reverse-subtracted probes, 66 cDNA candidates displaying visible positive differential expression were selected for further analysis. In order to reduce the possibility of isolating false-positive clones, these 66 candidates were screened in a second round by reverse Northern hybridization. Seventeen candidates with elevated expression in $n u c-2 A$ mutant were identified (Fig. 1), sequenced, and the results of similarity searches against the $N$. crassa database are summarized in Table 1.

The differential expression of four of these cDNA clones was confirmed by both virtual and Northern blot analyses (Fig. 2). The translation initiation factor transcript (EST D3; Table 1, Fig. 2) encodes a subunit protein of the multimeric eukaryotic translation initiation factor 3 (eIF3d; Bandyopadhyay et al., 2002), one of the largest and most complex of the eIFs for global eukaryotic mRNA translations (Hershey et al., 1996; Dong \& Zhang, 2006; Hinnebusch, 2006). In Schizosaccharomyces pombe, eIF3 has a core complex consisting of five protein subunits and several noncore subunits, including the eIF3d. Furthermore, two eIF3 subcomplexes containing different noncore proteins were also found in addition to the five core subunits each, what may confer different functions to the core complex of eIF3 and, therefore, affect the initiation of translation of more restricted mRNA species (Zhou et al., 2005). Furthermore, evidence 
(a)
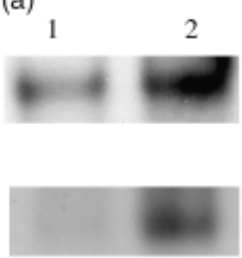

$\mathrm{C} 4$

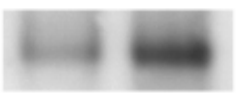

C6

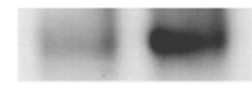

D3

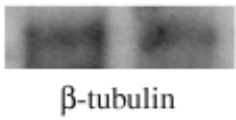

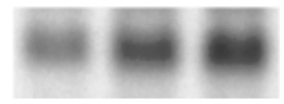
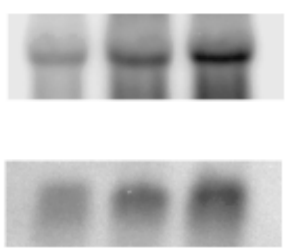

(b)
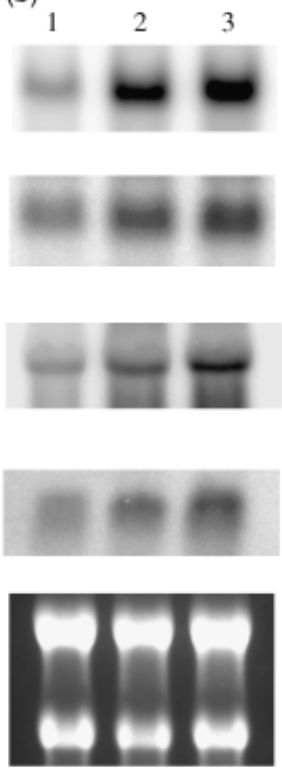

rRNA

Fig. 2. Gene expression analysis. (a) Virtual Northern analyses of cDNA clones up-regulated in the nuc-2A mutant strain. Control: $\beta$-tubulin revealing equal loading of the lanes. (b) Northern blot analyses of genes using total RNA from Neurospora crassa. Ethidium bromide-stained rRNA bands are shown for comparison of the quantities of loaded RNA. Lanes 1 and 2 represent, respectively, the wild type and nuc-2A mutant strains grown in low-Pi. Lane 3 represents the wild type strain grown in high-Pi. The identification and functional description of the clones are shown in Table 1.

now indicates that eIF3 complex influences a wide range of functions, including interactions with other eIFs and the proteasome (Chang \& Schwechheimer, 2004), assembly of the eIF2-GTP-Met-tRNA ${ }^{\text {Met }}$ ternary complex (TC), and binding of TC to the $40 \mathrm{~S}$ ribosomal subunit (Hinnebusch, 2006). The concomitant up-regulation of the $40 \mathrm{~S}$ ribosomal proteins S13, S16, and the ubiquitin-ribosomal protein S27a fusion protein (Tarawneh et al., 1994; Catic \& Ploegh, 2005) (ESTs C6, C4, and A7/F6, respectively; Table 1, Fig. 2) reinforces the proposed specificity of the interaction between the eIF3 complexes with the $40 \mathrm{~S}$ ribosomal subunit, which may result in the recruitment of the cellular translation machinery responsible for the translation initiation of a subpopulation of mRNAs. Therefore, the differential expression of these transcripts that occurs in the nuc- $2 \mathrm{~A}$ mutant or in the wild-type strains of $N$. crassa, respectively, grown in low- or high-Pi medium (Fig. 2) could account for the regulation of the Pi-repressible phosphatases (Metzenberg, 1979). In fact, these ESTs were expressed when the nuc2 gene is nonfunctional, as it occurs in this gene when the wild-type strain is grown in sufficient Pi (Fig. 2).

It can also be observed that among these ESTs enriched in the nuc-2 mutant strain grown under Pi starvation, functional grouping identified putative proteins possibly

involved in other cellular processes related or not to the regulation of protein synthesis (Table 1). Furthermore, some of these genes are now known to play essential roles in signaling transduction mechanisms controlling specific aspects of cellular differentiation in eukaryotic organisms (Wei \& Deng, 2003; Harari-Steinberg \& Chamovitz, 2004). Hence, their characterization may be relevant to a further understanding of the molecular events involved in phosphorus sensing in N. crassa.

\section{Acknowledgements}

This work was supported by grants from the Brazilian funding agencies FAPESP, CNPq, CAPES, and FAEPA. We thank A. Borghi for the English manuscript review, and P.R. Sanches, R.A. Ferreira, and M. Mazucato for technical assistance.

\section{Authors contribution}

D.E.G. and H.C.S.S. contributed equally to this work.

\section{References}

Altschul SF, Madden TL, Schaffer AA, Zhang J, Zhang Z, Miller W \& Lipman DJ (1997) Gapped BLAST and PSI-BLAST: a new generation of protein database search programs. Nucleic Acids Res 25: 3389-3402.

Bandyopadhyay A, Lakshmanan V, Matsumoto T, Chang EC \& Maitra U (2002) Moel and spInt6, the fission yeast homologues of mammalian translation initiation factor 3 subunits p66 (eIF3d) and p48 (eIF3e), respectively, are required for stable association of eIF3 subunits. J Biol Chem 277: 2360-2367.

Cai X \& Zhang Y (2006) Molecular evolution of the ankyrin gene family. Mol Biol Evol 23: 550-558.

Catic A \& Ploegh HL (2005) Ubiquitin - conserved protein or selfish gene? Trends Biochem Sci 30: 600-604.

Chang EC \& Schwechheimer C (2004) ZOMES III: the interface between signalling and proteolysis. EMBO Rep 5: 1041-1045.

Diatchenko L, Lau YF, Campbell AP et al. (1996) Suppression subtractive hybridization: a method for generating differentially regulated or tissue-specific CDNA probes and libraries. Proc Natl Acad Sci USA 93: 6025-6030.

Dong Z \& Zhang JT (2006) Initiation factor eIF3 and regulation of mRNA translation, cell growth, and cancer. Crit Rev Oncol Hematol 59: 169-180.

Franz O, Bruchhaus I \& Roeder T (1999) Verification of differential gene transcription using virtual Northern blotting. Nucleic Acids Res 27: e3.

Galagan JE, Calvo SE, Borkovich KA et al. (2003) The genome sequence of the filamentous fungus Neurospora crassa. Nature 422: 859-868. 
Han SW \& Rossi A (1989) Acid phosphatase (EC 3.1.3.2) synthesis by phosphorus regulatory mutant strains of Neurospora crassa. Braz J Med Biol Res 22: 423-431.

Harari-Steinberg O \& Chamovitz DA (2004) The COP9 signalosome: mediating between kinase signaling and protein degradation. Curr Protein Pept Sci 5: 185-189.

Hershey JW, Asano K, Naranda T, Vornlocher HP, Hanachi P \& Merrick WC (1996) Conservation and diversity in the structure of translation initiation factor eIF3 from humans and yeast. Biochimie 78: 903-907.

Hinnebusch AG (2006) eIF3: a versatile scaffold for translation initiation complexes. Trends Biochem Sci 31: 553-562.

Ishikawa T, Toh EA, Uno I \& Hasunuma K (1969) Isolation and characterization of nuclease mutants in Neurospora crassa. Genetics 63: 75-92.

Kang S \& Metzenberg RL (1990) Molecular analysis of $n u c-1^{+}$, a gene controlling phosphorus acquisition in Neurospora crassa. Mol Cell Biol 10: 5839-5848.

Kang S \& Metzenberg RL (1993) Insertional mutagenesis in Neurospora crassa: cloning and molecular analysis of the preg $^{+}$ gene controlling the activity of the transcriptional activator NUC-1. Genetics 133: 193-202.

Knight JP, Daly TM \& Bergman LW (2004) Regulation by phosphorylation of Pho81p, a cyclin-dependent kinase inhibitor in Saccharomyces cerevisiae. Curr Genet 46: 10-19.

Metzenberg RL (1979) Implications of some genetic control mechanisms in Neurospora. Microbiol Rev 43: 361-383.

Mewes HW, Albermann K, Heumann K, Liebl S \& Pfeiffer F (1997) MIPS: a database for protein sequences, homology data and yeast genome information. Nucleic Acids Res 25: 28-30.

Mewes HW, Frishman D, Guldener U, Mannhaupt G, Mayer K, Mokrejs M, Morgenstern B, Munsterkotter M, Rudd S \& Weil B (2002) MIPS: a database for genomes and protein sequences. Nucleic Acids Res 30: 31-34.
Michaely P \& Bennett V (1992) The ANK repeat: a ubiquitous motif involved in macromolecular recognition. Trends Cell Biol 2: 127-129.

Nyc JF, Kadner RJ \& Crocken BJ (1966) A repressible alkaline phosphatase in Neurospora crassa. J Biol Chem 241: 1468-1472.

Peleg Y, Aramayo R, Kang S, Hall JG \& Metzenberg RL (1996a) NUC-2, a component of the phosphate-regulated signal transduction pathway in Neurospora crassa, is an ankyrin repeat protein. Mol Gen Genet 252: 709-716.

Peleg Y, Addison R, Aramayo R \& Metzenberg RL (1996b) Translocation of Neurospora crassa transcription factor NUC-1 into the nucleus is induced by phosphorus limitation. Fungal Genet Biol 20: 185-191.

Rodrigues SA \& Rossi A (1985) Effect of phosphate levels on the synthesis of acid phosphatases (EC 3.1.3.2) in Neurospora crassa. Genet Res 45: 239-249.

Sambrook J, Fritsch EF \& Maniatis T (1989) Molecular Cloning: A Laboratory Manual, Cold Springer Harbor Laboratory Press, New York, USA.

Tarawneh KA, Anumula KR \& Free SJ (1994) The isolation and characterization of a Neurospora crassa gene (ubi::crp-6) encoding a ubiquitin-40S ribosomal protein fusion protein. Gene 147: 137-140.

Vogel HJ (1956) A convenient growth medium for Neurospora crassa. Microbial Genet Bull 13: 42-43.

Waters NC, Knight JP, Creasy CL \& Bergman LW (2004) The yeast Pho80-Pho85 cyclin-CDK complex has multiple substrates. Curr Genet 46: 1-9.

Wei N \& Deng XW (2003) The COP9 signalosome. Annu Rev Cell Dev Biol 19: 261-286.

Zhou C, Arslan F, Wee S, Krishnan S, Ivanov AR, Oliva A, Leatherwood J \& Wolf DA (2005) PCI proteins eIF3e and eIF3 $\mathrm{m}$ define distinct translation initiation factor 3 complexes. BMC Biology 3: 14. 
Elsevier Editorial System(tm) for Microbiological Research

Manuscript Draft

Manuscript Number:

Title: Transcriptional changes in the nuc-2A mutant strain of Neurospora crassa cultivated under conditions of phosphate shortage

Article Type: Research Paper

Keywords: Neurospora crassa; ankyrin repeat protein; histone, Pi sensing; woronin body

Corresponding Author: Prof Antonio Rossi, PhD

Corresponding Author's Institution: Universidade de São Paulo

First Author: Diana E. Gras

Order of Authors: Diana E. Gras; Henrique C. S. Silveira; Nalu T. A. Peres; Pablo R. Sanches; Nilce M Martinez-Rossi; Antonio Rossi, PhD

Abstract: $\quad$ The molecular mechanism that controls the response to phosphate shortage in Neurospora crassa involves four regulatory genes-nuc-2, preg, pgov, and nuc-1. Phosphate shortage is sensed by the nuc-2 gene, the product of which inhibits the functioning of the PREG-PGOV complex. This allows the translocation of the transcriptional factor NUC-1 into the nucleus, which activates the transcription of phosphate-repressible phosphatases. The nuc-2A mutant strain of $\mathrm{N}$. crassa carries a loss-of-function mutation in the nuc-2 gene, which encodes an ankyrin-like repeat protein. In this study, we identified transcripts that are downregulated in the nuc$2 \mathrm{~A}$ mutant strain. Functional grouping of these expressed sequence tags allowed the identification of genes that play essential roles in different cellular processes such as transport, transcriptional regulation, signal transduction, metabolism, protein synthesis, protein fate, and development. These results reveal novel aspects of the phosphorus-sensing network in N. crassa. 

Dr. Jürgen Wendland, Editor-in-Chief of Microbiological Research

Dear Dr. Wendland,

Please find attached the manuscript entitled "Transcriptional changes in the nuc$2 A$ mutant strain of Neurospora crassa cultivated under conditions of phosphate shortage" by Grass, Silveira, Peres, Sanches, Martinez-Rossi and myself. We would like to have it considered for publication in Microbiological Research.

Thanking you in advance and hopping to hear from you soon, I remain,

Yours Sincerely

Dr. Antonio Rossi

Dept Bioquímica e Imunologia

Faculdade de Medicina de Ribeirão Preto - USP

E-mail: anrossi@usp.br

Fax: +551636336840 
1 Transcriptional changes in the nuc-2A mutant strain of Neurospora crassa

2 cultivated under conditions of phosphate shortage

3

4 Diana E. Gras ${ }^{\mathrm{a}}$, Henrique C.S. Silveira ${ }^{\mathrm{a}}$, Nalu T.A. Peres ${ }^{\mathrm{a}}$, Pablo R. Sanches ${ }^{\mathrm{a}}$, Nilce M.

$5 \quad$ Martinez-Rossi ${ }^{\mathrm{a}}$, Antonio Rossi ${ }^{\mathrm{b}}{ }^{*}$

6

7 Departamento de Genética, Faculdade de Medicina de Ribeirão Preto, Universidade de São

8 Paulo, 14049-900, Ribeirão Preto, SP, Brazil

9

10 bepartamento de Bioquímica e Imunologia, Faculdade de Medicina de Ribeirão Preto,

11 Universidade de São Paulo, 14049-900, Ribeirão Preto, SP, Brazil

12

13 *Corresponding author. Tel.: + 55163602 3112, fax: +55 1636336840 .

14 E-mail address: anrossi@usp.br (A. Rossi)

15

16

17 Running Title: Transcriptional changes in the nuc- $2 A$ mutant strain of N. crassa

18

19

20 Keywords: ankyrin repeat protein; histone; Pi sensing; Woronin body

21

22 


\section{Summary}

The molecular mechanism that controls the response to phosphate shortage in Neurospora crassa involves four regulatory genes—nuc-2, preg, pgov, and nuc-1. Phosphate shortage is sensed by the nuc-2 gene, the product of which inhibits the functioning of the PREG-PGOV complex. This allows the translocation of the transcriptional factor NUC-1 into the nucleus, which activates the transcription of phosphate-repressible phosphatases. The $n u c-2 A$ mutant strain of $N$. crassa carries a lossof-function mutation in the $n u c-2$ gene, which encodes an ankyrin-like repeat protein. In this study, we identified transcripts that are downregulated in the $n u c-2 A$ mutant strain. Functional grouping of these expressed sequence tags allowed the identification of genes that play essential roles in different cellular processes such as transport, transcriptional regulation, signal transduction, metabolism, protein synthesis, protein fate, and development. These results reveal novel aspects of the phosphorus-sensing network in $N$. crassa.

\section{Introduction}

Phosphorus, a key element in the survival of all living organisms, is a crucial constituent of genetic information and is involved in energy transport, photosynthesis, and cellular signaling responses to environmental, developmental, or physiological modifications. In response to phosphorus shortage, most microorganisms modulate their metabolism through a complex dosage titration and hierarchical regulatory network that involves several genes that sense the availability of phosphate (Pi) and signal the derepression of the enzymes necessary for fulfilling the cell's Pi requirements. The molecular mechanism controlling this response in Neurospora crassa involves four regulatory 
genes - nuc-2, preg, pgov, and nuc-1 (Metzenberg, 1979). The nuc-2 gene encodes an ankyrin-like repeat protein (Peleg et al., 1996). The preg and pgov genes encode a cyclinlike and a mitogen-activated protein kinase, respectively, whereas the nuc- 1 gene encodes the transcription regulator NUC-1 (Peleg et al., 1996). The availability of Pi is sensed by the $n u c-2$ gene, the transcription of which is increased in response to Pi shortage (Peleg et al., 1996). The NUC-2 protein inhibits the functioning of the PREG-PGOV complex, facilitating NUC-1 translocation into the nucleus under conditions of Pi shortage. Thus, the PREG/PGOV complex is implicated in the sequestering of NUC-1 in the cytosol under conditions of sufficient Pi (Peleg et al., 1996).

Ankyrin repeat proteins have been detected in organisms ranging from viruses to humans and are involved in several physiological processes such as cytoskeletal integrity, transcriptional and translational regulation, cell signaling, development and differentiation, apoptosis, and vesicular trafficking (Bussink and Osmani, 1998; Cai and Zhang, 2006).

Loss-of-function mutations in the $N$. crassa nuc-2 gene may alter the transcriptional profile of genes other than those encoding phosphatases in response to Pi shortage (Gras et al., 2007; Wu et al., 2004). To identify transcriptional changes in the $N$. crassa nuc-2A mutant strain cultivated under conditions of Pi shortage, a suppression subtractive hybridization (SSH) library was constructed. Control and mutant cDNAs were used as the tester and driver, respectively, in order to identify genes that are downregulated in the nuc- $2 A$ mutant strain in response to Pi shortage. Functional grouping of these expressed sequence tags (ESTs) allowed the identification of genes involved in chromatin condensation, oxidative phosphorylation, and nutrient transport. The results revealed novel aspects of the functioning of the $N$. crassa nuc-2 gene. 


\section{Materials and methods}

\section{Strains and culture conditions}

The St.L.74-OR23-1VA (control strain, FGSC No. 2489) and nuc-2A mutant (FGSC No. 1996) strains of N. crassa (Ishikawa et al., 1969; Peleg et al., 1996) used in this study were obtained from the Fungal Genetic Stock Center, University of Missouri, Kansas City, Missouri (McCluskey, 2003). For the gene expression assay, conidia from each strain (approximately $10^{6}$ cells $/ \mathrm{mL}$ ) were cultivated at $30^{\circ} \mathrm{C}$ with continuous shaking at $200 \mathrm{rpm}$ for $5 \mathrm{~h}$ in a low-Pi medium (10 $\mu \mathrm{M}$ Pi, final concentration) at $\mathrm{pH} 5.4$ (buffered with $50 \mathrm{mM}$ sodium citrate) and supplemented with $44 \mathrm{mM}$ sucrose as the carbon source (Rodrigues and Rossi, 1985).

\section{RNA isolation, SSH, and screening of subtracted cDNA clones}

One microgram of total RNA was extracted from mycelia using the NucleoSpin ${ }^{\circledR}$ RNA plant kit (BD Biosciences Clontech, Palo Alto, California). This was used to synthesize double-stranded cDNAs using the BD SMART ${ }^{\mathrm{TM}}$ PCR cDNA synthesis kit (BD Biosciences Clontech). The manufacturer's instructions were followed throughout the cDNA synthesis procedure.

SSH was performed between the driver (cDNA obtained from the $n u c-2 A$ strain cultivated for $5 \mathrm{~h}$ in a low-Pi medium buffered at $\mathrm{pH}$ 5.4) and tester (cDNA obtained from the control strain cultivated under the same conditions), as described earlier (Diatchenko et al., 1996), using the Clontech PCR-Select ${ }^{\mathrm{TM}}$ cDNA subtraction kit (BD Biosciences Clontech). The PCR product of subtraction was cloned into pGEM-T Easy Vector Systems (Promega, Madison, Wisconsin), and the plasmids were transformed into competent 
Escherichia coli cells and plated onto the surface of agar solidified LB medium supplemented with ampicillin $(50 \mu \mathrm{g} / \mathrm{mL})$. Based on the manufacturer's instructions, X-gal and IPTG were added to allow screening for insert-containing colonies. The white colonies of $E$. coli that contained individual inserts of the differentially expressed sequences in the tester population were selected, grown in ampicillin-LB medium at $37^{\circ} \mathrm{C}$ for $12 \mathrm{~h}$, and amplified by PCR using the nested primers 1 and 2R from the SSH kit and $2 \mu \mathrm{L}$ of the $E$. coli culture as the template. The PCR cycle used was as follows: $94^{\circ} \mathrm{C}$ for $2 \mathrm{~min}$, followed by 30 cycles at $95^{\circ} \mathrm{C}$ for $30 \mathrm{~s}, 65^{\circ} \mathrm{C}$ for $30 \mathrm{~s}$, and $72^{\circ} \mathrm{C}$ for $1.5 \mathrm{~min}$. The PCR products were checked by electrophoresing $2 \mu \mathrm{L}$ of the product on a $2 \%$ agarose gel. Subsequently, $8 \mu \mathrm{L}$ of each reaction mixture was denatured by adding an equal volume of $0.6 \mathrm{~N} \mathrm{NaOH}$. For differential screening, $4 \mu \mathrm{L}$ of denatured DNA from each clone was spotted onto duplicate nylon membranes (Hybond-N+, GE Healthcare, Waukesha, Wisconsin) using a vacuum blotter.

Subtraction was also performed with the control strain as the driver and $n u c-2 A$ as the tester (both cultivated in a low-Pi medium, $\mathrm{pH}$ 5.4) to prepare the reverse-subtracted cDNA probe for differential screening. The arrayed clones (forward cDNA library) were hybridized with both forward- and reverse-subtracted cDNA probes, which were labeled with fluorescein using the Gene Images Random Prime labelling module (GE Healthcare, Buckinghamshire, UK). Hybridizations were performed overnight at $60^{\circ} \mathrm{C}$ under continuous agitation. Following hybridization, the membranes were incubated with an antifluorescein alkaline phosphatase conjugate and then washed. The detection reagent was applied (GE Healthcare), and the membranes were exposed to an X-ray film (Kodak Biomax MR Film, Manaus, Amazonas, Brazil). 


\section{DNA sequencing and northern blot analyses}

The plasmids from arrayed clones showing visible positive differential expression were purified and sequenced using the M13 forward primer. Sequencing was carried out with the ABI Prism BigDye Terminator Cycle sequencing kit, and the products were analyzed in an ABI Prism 377 DNA sequencer (Applied Biosystems, Foster City, California). The EST sequences showing high nucleotide quality were processed with the CAP3 software for contig assembly, and the corresponding open reading frames (ORFs) were identified in the $N$. crassa genome database (Galagan et al., 2003)

(http://www.broad.mit.edu/annotation/genome/neurospora/Home.html) and subjected to BLASTN and BLASTX search against the GenBank database

(http://www.ncbi.nlm.nih.gov). The functional catalog FunCat created by MIPS (http://mips.gsf.de/genre/proj/ncrassa/Search/Catalogs/catalog.jsp) was mined to associate functional categories with the identified N. crassa genes.

For validation of differential gene expression by northern blotting, the control and $n u c-2 A$ strains were cultivated as described to construct the subtractive suppressive cDNA library. Samples containing approximately $15 \mu \mathrm{g}$ of total RNA, extracted with the TRIzol reagent (Invitrogen, Carlsbad, California) were electrophoresed on a 1.5\% agarose gel containing formaldehyde, efficiently blotted onto Hybond-N+ membranes, and hybridized with purified cDNA probes labeled with $\left[\alpha-{ }^{32} \mathrm{P}\right] \mathrm{dCTP}$.

\section{Results}

The SSH library was constructed to isolate the transcripts that were downregulated in the $n u c-2 A$ mutant strain of $N$. crassa that had been cultivated for $5 \mathrm{~h}$ under Pi shortage 
142 at $\mathrm{pH}$ 5.4. This library generated an EST population with an average sequence length of

143650 nucleotides. Following differential screening of these cDNA clones using both the

144 forward- and reverse-subtracted probes, 96 candidates that showed visible positive

145 differential expression were selected and then subjected to a second round of screening by

146 reverse northern hybridization, which was followed by sequencing. The corresponding

147 ORFs identified in the $N$. crassa genome database revealed 52 nonredundant unigenes 148 (Table 1).

149 The differential expression of eight of these arbitrarily chosen cDNA clones that 150 encode NADP-specific glutamate dehydrogenase, hexagonal-1 peroxisome protein (HEX-

151 1), ATP synthase alpha chain, pyruvate dehydrogenase E1 component, histone H4, S-

152 adenosyl-L-homocysteine hydrolase, hexose transporter-like protein, and histone H3 was

153 confirmed by northern blot analyses. The northern blots shown in Fig. 1 are representative

154 of the results obtained from three independent experiments. It was also observed that

155 growth in a liquid medium and conidia production on a solid medium were the same in

156 both the control and $n u c-2 A$ mutant strains.

157

158 Discussion

159 Despite the progress achieved through genomic expression analysis, molecular

160 details of the metabolic responses to changes in exogenous Pi levels have not yet been fully

161 elucidated (Ogawa et al., 2000). Indeed, recent studies have shown that $N$. crassa preg and

$162 n u c-2$ genes also modulate the transcription of genes other than those encoding

163 phosphatases in response to Pi shortage (Gras et al., 2007; Leal et al., 2007).

164 The SSH methodology facilitates the cloning of ESTs that represent differentially

165 expressed genes by comparing two mRNA populations. This method combines the 
166 suppression PCR technique with the normalization and subtraction steps in a single

167 reaction, thus increasing the possibility of identifying weakly expressed genes (Diatchenko

168 et al., 1996). By using this technique, rare differentially expressed sequences can be

169 detected by suppressing the amplification of transcripts that are in abundance (Moody,

170 2001). Among the 52 unigenes that are downregulated in the N. crassa nuc-2A mutant

171 strain cultivated under conditions of Pi shortage, two showed similarity with the histones

$172 \mathrm{H} 3$ and H4 (Table 1, Fig. 1). The DNA in eukaryotic cells is packaged into highly

173 conserved nucleosome cores, which are octamers consisting of two copies of each of the

174 histone proteins $\mathrm{H} 2 \mathrm{~A}, \mathrm{H} 2 \mathrm{~B}, \mathrm{H} 3$, and $\mathrm{H} 4$. The $\mathrm{N}$-terminal tails of the core histone proteins

175 interact with the neighboring proteins and affect the chromatin structure, thus influencing

176 global gene expression in eukaryotic organisms (Millar and Grunstein, 2006). In

177 Saccharomyces cerevisiae, depletion of histone H4 and nucleosomes activates, for

178 example, the PHO5 gene (a Pi-repressible acid phosphatase gene) even under Pi-repressible

179 conditions (Han et al., 1988).

180 It was also observed that functional grouping of the downregulated ESTs in the nuc-

$1812 A$ mutant strain allowed the identification of putative proteins that are involved in diverse

182 cellular processes such as oxidative phosphorylation (ATP synthase or $\mathrm{H}^{+}$-ATPase),

183 transmethylation reactions (S-adenosyl-L-homocysteine hydrolase), dehydrogenation

184 reactions, and hexose transport (Marques et al., 2007; Thykaer et al., 2008). The $\mathrm{H}^{+}-$

185 ATPases are ion pumps that use ATP to transport cations against a concentration gradient,

186 thereby maintaining the intracellular $\mathrm{pH}$ and membrane potential. $\mathrm{H}^{+}$-ATPases also provide

187 energy for nutrient uptake and ion exchange by secondary transporters, which probably

188 allows Pi uptake in cells grown under limiting Pi conditions. In fungi, as in all other

189 eukaryotic organisms, transporter systems have an important role in essential nutrient and 
190 ion uptake, secretion of metabolic products and deleterious substances, and communication

191 between cells and the environment. Two major classes of transporters have been implicated

192 in these processes - the ATP-binding cassettes (ABC) superfamily and the major facilitator

193 superfamily (MFS). Both transporter classes are distinct in terms of their primary structure

194 and the mechanism of energy coupling (Higgins, 2007). The hexose transporter gene

195 isolated here encodes a protein belonging to the MFS superfamily. In S. cerevisiae,

196 phosphorus and nitrogen signaling in $\mathrm{Pi}$ - and nitrogen-starved cells, respectively, requires

197 the presence of glucose, suggesting that the eukaryotic cell integrates information from

198 different nutrient-sensing systems by using overlapping signal transduction pathways

199 (Giots et al., 2003). Another interesting feature is the downregulation of the hex-1 transcript 200 in the $N$. crassa nuc-2A mutant strain cultured under conditions of Pi shortage (Fig. 1); this 201 gene is unique to filamentous fungi (Tenney et al., 2000). HEX-1 is the major component 202 of the Woronin body, a septal pore-associated organelle crucial for the resealing of the 203 plasma membrane, which prevents cytoplasmic bleeding following hyphal injury (Jedd and 204 Chua, 2000; Liu et al., 2008; Maruyama et al., 2005; Tenney et al., 2000; Würtz et al., 205 2008). Woronin bodies are also regarded as being necessary for efficient pathogenesis 206 (Soundararajan et al., 2004), conidiation (Simon et al., 2005), and survival during nitrogen 207 starvation (Soundararajan et al., 2004). These organelles may function in response to 208 diverse environmental stresses (Soundararajan et al., 2004; Tey et al., 2005), including Pi 209 shortage in the N. crassa wild-type strain.

210 In conclusion, SSH was successfully used to isolate downregulated genes in the $N$.

211 crassa nuc-2A mutant strain grown under conditions of Pi shortage at acidic $\mathrm{pH}$. Functional 212 grouping of these ESTs allowed the identification of genes that play essential roles in 213 different cellular processes such as transport, transcriptional regulation, signal transduction, 
214 metabolism, protein synthesis, development, and protein fate. Another interesting result

215 was the identification of genes encoding ribosomal putative proteins that are downregulated

216 in the $n u c-2 A$ mutant strain. These genes are probably components of specific translational

217 machinery that is recruited when the $n u c-2$ gene is functional. Considering that $\mathrm{Pi}$

218 availability is probably sensed by the $n u c-2$ gene, identification of other genes modulated

219 by the NUC-2 protein reveals novel aspects of the phosphorus-sensing network,

220 emphasizing convergent but complex metabolic regulation under conditions of Pi shortage

221 in N. crassa.

223 Acknowledgements

224 This study was supported by grants from the Brazilian funding agencies FAPESP, CNPq, 225 CAPES, and FAEPA. We thank R. A. Ferreira and M. Mazucato for technical assistance.

\section{References}

Bussink HJ, Osmani SA. A cyclin-dependent kinase family member (PHOA) is required to link developmental fate to environmental conditions in Aspergillus nidulans. EMBO J 1998;17:3990-4003.

Cai X, Zhang Y. Molecular evolution of the ankyrin gene family. Mol Biol Evol 2006;23:550-558.

Diatchenko L, Lau YF, Campbell AP, et al. Suppression subtractive hybridization: a libraries. Proc Natl Acad Sci USA 1996;93:6025-6030. 
237 Galagan JE, Calvo SE, Borkovich KA, et al. The genome sequence of the filamentous fungus Neurospora crassa. Nature 2003;422:859-868.

239 Giots F, Donaton MC, Thevelein JM. Inorganic phosphate is sensed by specific phosphate carriers and acts in concert with glucose as a nutrient signal for activation of the protein kinase A pathway in the yeast Saccharomyces cerevisiae. Mol Microbiol

Gras DE, Silveira HC, Martinez-Rossi NM, Rossi A. Identification of genes displaying differential expression in the nuc-2 mutant strain of the mold Neurospora crassa grown under phosphate starvation. FEMS Microbiol Lett 2007;269:196-200.

Han M, Kim UJ, Kayne P, Grunstein M. Depletion of histone H4 and nucleosomes activates the PHO5 gene in Saccharomyces cerevisiae. EMBO J 1988;7:2221-2228.

Higgins CF. Multiple molecular mechanisms for multidrug resistance transporters. Nature 2007;446:749-757.

250 Ishikawa T, Toh EA, Uno I, Hasunuma K. Isolation and characterization of nuclease mutants in Neurospora crassa. Genetics 1969;63:75-92.

Jedd G, Chua NH. A new self-assembled peroxisomal vesicle required for efficient resealing of the plasma membrane. Nat Cell Biol 2000;2:226-231.

254 Leal J, Squina FM, Martinez-Rossi NM, Rossi A. The transcription of the gene for isoorotate decarboxylase (IDCase), an enzyme of the thymidine salvage pathway, is downregulated in the $\mathrm{preg}^{c}$ mutant strain of Neurospora crassa grown under phosphate starvation. Can J Microbiol 2007;53:1011-1015. body biogenesis by peroxisomal protein sorting. J Cell Biol 2008;180:325-339. 
260 Marques I, Dencher NA, Videira A, Krause F. Supramolecular organization of the respiratory chain in Neurospora crassa mitochondria. Eukaryot Cell 2007;6:23912405.

Maruyama J, Juvvadi PR, Ishi K, Kitamoto K. Three-dimensional image analysis of plugging at the septal pore by Woronin body during hypotonic shock inducing hyphal tip bursting in the filamentous fungus Aspergillus oryzae. Biochem Biophys Res Commun 2005;331:1081-1088.

McCluskey K. The Fungal Genetics Stock Center: from molds to molecules. Adv Appl Microbiol 2003;52:245-262.

Metzenberg RL. Implications of some genetic control mechanisms in Neurospora. Microbiol Rev 1979;43:361-383.

Millar CB, Grunstein M. Genome-wide patterns of histone modifications in yeast. Nat Rev Mol Cell Biol 2006;7:657-666.

Moody DE. Genomics techniques: an overview of methods for the study of gene expression. J Anim Sci 2001;79:E128-E135.

Ogawa N, DeRisi J, Brown PO. New components of a system for phosphate accumulation and polyphosphate metabolism in Saccharomyces cerevisiae revealed by genomic expression analysis. Mol Biol Cell 2000;11:4309-4321.

Peleg Y, Addison R, Aramayo R, Metzenberg RL. Translocation of Neurospora crassa transcription factor NUC-1 into the nucleus is induced by phosphorus limitation. Fungal Genet Biol 1996;20:185-191. phosphate-regulated signal transduction pathway in Neurospora crassa, is an ankyrin repeat protein. Mol Gen Genet 1996;252:709-716. 
284 Rodrigues SA, Rossi A. Effect of phosphate levels on the synthesis of acid phosphatases (EC 3.1.3.2) in Neurospora crassa. Genet Res 1985;45:239-249.

Simon UK, Bauer R, Rioux D, Simard M, Oberwinkler F. The vegetative life-cycle of the clover pathogen Cymadothea trifolii as revealed by transmission electron microscopy. Mycol Res 2005;109:764-778.

Soundararajan S, Jedd G, Li X, Ramos-Pamplona M, Chua NH, Naqvi NI. Woronin body function in Magnaporthe grisea is essential for efficient pathogenesis and for survival during nitrogen starvation stress. Plant Cell 2004;16:1564-1574.

Tenney K, Hunt I, Sweigard J, Pounder JI, McClain C, Bowman EJ, Bowman BJ. Hex-1, a gene unique to filamentous fungi, encodes the major protein of the Woronin body and functions as a plug for septal pores. Fungal Genet Biol 2000;31:205-217.

Tey WK, North AJ, Reyes JL, Lu YF, Jedd G. Polarized gene expression determines woronin body formation at the leading edge of the fungal colony. Mol Biol Cell $2005 ; 16: 2651-2659$.

Thykaer J, Rueksomtawin K, Noorman H, Nielsen J. NADPH-dependent glutamate dehydrogenase in Penicillium chrysogenum is involved in regulation of beta-lactam production. Microbiology 2008;154:1242-1250.

Wu D, Dou X, Hashmi SB, Osmani SA. The Pho80-like cyclin of Aspergillus nidulans regulates development independently of its role in phosphate acquisition. J Biol Chem 2004;279:37693-37703. formation of Woronin bodies in Saccharomyces cerevisiae upon heterologous expression of a single protein. FEBS J 2008;275:2932-2941. 


\section{$308 \quad$ Figure legend}

309

310 Figure 1 Gene expression analysis. Northern blot analyses of eight genes using the total

311 RNA obtained from strains of Neurospora crassa cultured for $5 \mathrm{~h}$ at $30^{\circ} \mathrm{C}$ in a low-Pi

312 liquid medium at $\mathrm{pH}$ 5.4. Lanes 1 and 2 represent the wild type and $n u c-2 A$ mutant

313 strains, respectively. The ethidium bromide-stained rRNA bands are shown for

314 comparison of the quantities of loaded RNA. Identification of the clones and their

315 functional description are shown in Table 1. The numbers associated with the bars (axes

316 of ordinates) indicate the fold differences relative to the intensity of the northern blots

317 shown by each clone expressed in the control (Bar 1) and nuc-2A (Bar 2) strains, as

318 established by densitometric analysis. 
Table 1 Genes down-regulated in the Neurospora crassa nuc- $2 A$ mutant strain identified by SSH and reverse Northern hybridization

\begin{tabular}{|c|c|c|c|}
\hline $\begin{array}{l}\text { GenBank } \\
\text { accession } \\
\text { number }\end{array}$ & $\begin{array}{l}\text { Number of } \\
\text { clones }\end{array}$ & $\begin{array}{l}\text { Predicted } \\
\text { ORF }\end{array}$ & Putative gene products/MIPS functional category \\
\hline FK707478 & 4 & NCU02509 & 60S ribosomal protein L11/Protein synthesis \\
\hline$\overline{\text { FK707482 }}$ & 2 & NCU01195 & NADP-specific glutamate dehydrogenase/Metabolism \\
\hline FK707484 & 2 & NCU08332 & HEX1_NEUCR Woronin body major protein precursor/Development \\
\hline$\underline{\text { FK707486 }}$ & 2 & NCU02707 & Hypothetical protein similar to $60 \mathrm{~S}$ ribosomal protein yL16a/Protein synthesis \\
\hline$\underline{F K 707488}$ & 2 & NCU03988 & $60 \mathrm{~S}$ ribosomal protein L18/Protein synthesis \\
\hline$\overline{\text { FK707490 }}$ & 2 & NCU10042 & Enolase/Metabolism \\
\hline FK707492 & 2 & NCU00258 & 40S ribosomal protein $\mathrm{S} 7 /$ Protein synthesis \\
\hline FK707494 & 1 & NCU04603 & Predicted protein related to rasp $\mathrm{f} 7$ allergen/Metabolism \\
\hline FK707495 & 1 & NCU02514 & ATP synthase alpha chain, mitochondrial precursor/Transport \\
\hline FK707496 & 1 & NCU03050 & ARP2/3 complex $34 \mathrm{kDa}$ subunit/Protein fate \\
\hline$\underline{\mathbf{F K 7 0 7 4 9 7}}$ & 1 & NCU08940 & Ubiquinol-cytochrome c reductase complex $14 \mathrm{kDa}$ protein/Energy \\
\hline$\underline{\overline{\text { FK707498 }}}$ & 1 & NCU07829 & 60 S ribosomal protein L7/Protein synthesis \\
\hline$\underline{\underline{\text { FK707499 }}}$ & 1 & NCU08500 & $40 \mathrm{~S}$ ribosomal protein $\mathrm{S} 8 /$ Protein synthesis \\
\hline$\underline{\overline{\text { FK707500 }}}$ & 1 & NCU01523 & GTP-binding protein ypt3/Cellular communication-Signal transduction mechanism \\
\hline$\overline{\text { FK707501 }}$ & 1 & NCU05231 & Conserved hypothetical protein/Unclassified protein \\
\hline$\underline{\overline{\text { FK707502 }}}$ & 1 & NCU03302 & Probable 60 S ribosomal protein L36/Protein synthesis \\
\hline$\overline{\text { FK707503 }}$ & 1 & NCU03565 & Probable ribosomal protein L26/Protein synthesis \\
\hline$\overline{\text { FK707504 }}$ & 1 & NCU11339 & Predicted protein/Unclassified protein \\
\hline$\overline{\text { FK707505 }}$ & 1 & NCU00212 & Histone H4/Transcription \\
\hline$\overline{\text { FK707506 }}$ & 1 & NCU01633 & Protein similar to hexose transporter/Transport \\
\hline$\overline{\text { FK707507 }}$ & 1 & NCU00147 & Hypothetical protein similar to SIPL-ARD family protein/Unclassified protein \\
\hline$\overline{\text { FK707508 }}$ & 1 & NCU01948 & Probable ribosomal protein L21.e.A, cytosolic/Protein synthesis \\
\hline$\overline{\text { FK707509 }}$ & 1 & NCU04924 & Hypothetical protein similar to phosphatidyl synthase/Metabolism \\
\hline$\overline{\text { FK707510 }}$ & 1 & NCU06043 & Hypothetical protein similar to GPR-FUN34 family protein/Metabolism \\
\hline$\overline{\text { FK707511 }}$ & 1 & NCU03004 & Pyruvate dehydrogenase E1 component/Metabolism \\
\hline$\overline{\text { FK707512 }}$ & 1 & NCU07930 & S-adenosyl-L-homocysteine hydrolase/Metabolism \\
\hline$\overline{\text { FK707513 }}$ & 1 & NCU00951 & Inorganic pyrophosphatase/Metabolism \\
\hline
\end{tabular}




\begin{tabular}{|c|c|c|c|}
\hline FK707514 & 1 & NCU01991 & Predicted protein/Unclassified protein \\
\hline$\overline{\text { FK707515 }}$ & 1 & NCU01559 & Predicted protein/Unclassified protein \\
\hline$\overline{\text { FK707516 }}$ & 1 & NCU09475 & 40s ribosomal protein $\mathrm{s} 5 /$ Protein synthesis \\
\hline$\overline{\text { FK707517 }}$ & 1 & NCU08195 & Arginyl-tRNA synthetase/Protein synthesis \\
\hline$\overline{\text { FK707518 }}$ & 1 & NCU08502 & 40 S ribosomal protein $\mathrm{S} 6 /$ Protein synthesis \\
\hline FK707519 & 1 & NCU02729 & Related to WD repeat protein IEF SSP 9502/Transcription \\
\hline$\overline{\text { FK707520 }}$ & 1 & NCU02010 & 2-isopropylmalate synthase/Metabolism \\
\hline FK707521 & 1 & NCU03827 & Related to $40 \mathrm{~S}$ ribosomal protein $\mathrm{S} 9$, mitochondrial precursor/Protein synthesis \\
\hline FK707522 & 1 & NCU01068 & Conserved hypothetical protein/Unclassified protein \\
\hline FK707523 & 1 & NCU02274 & Cytosolic serine hydroxymethyltransferase/Metabolism \\
\hline FK707524 & 1 & NCU04542 & Predicted protein/Unclassified protein \\
\hline FK707525 & 1 & NCU04552 & 40 S ribosomal protein S26E/Protein synthesis \\
\hline FK707526 & 1 & NCU01635 & Histone H3/Transcription \\
\hline FK707527 & 1 & NCU06207 & C-5 sterol desaturase/Metabolism \\
\hline FK707528 & 1 & NCU09331 & Probable BRT1 protein/Interaction with the environment \\
\hline FK707529 & 1 & NCU05667 & Predicted protein/Unclassified protein \\
\hline FK707530 & 1 & NCU02066 & Related to excision repair protein RAD4/Cell cycle and DNA processing \\
\hline FK707531 & 1 & NCU04779 & $60 \mathrm{~S}$ ribosomal protein L8/Protein synthesis \\
\hline FK707532 & 1 & NCU06090 & Related to RRP14 - involved in ribosomal RNA processing/Unclassified protein \\
\hline FK707533 & 1 & NCU02380 & Threonyl-tRNA synthetase/Protein synthesis \\
\hline FK707534 & 1 & --- & aitochondria, assembly 3 (20731-20584)/uncharacterized \\
\hline FK707535 & 1 & --- & ${ }^{\mathrm{a}}$ Contig 7 (759234-759438)/uncharacterized \\
\hline FK707536 & 1 & --- & ${ }^{\mathrm{a}}$ Contig 1 (1304801-1304929)/uncharacterized \\
\hline FK707537 & 1 & --- & ${ }^{\mathrm{a}}$ Contig 1 (1650053-1650170)/uncharacterized \\
\hline FK707538 & 1 & --- & ${ }^{\mathrm{a}}$ Contig 15 (117148-117217)/uncharacterized \\
\hline
\end{tabular}


NCU01195

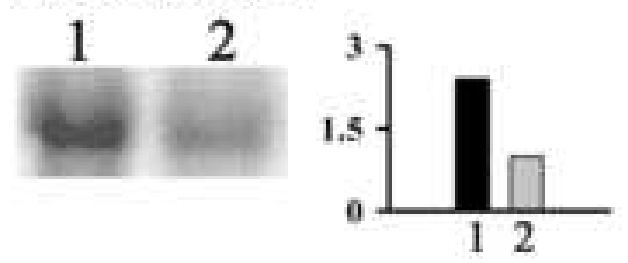

NCU02514

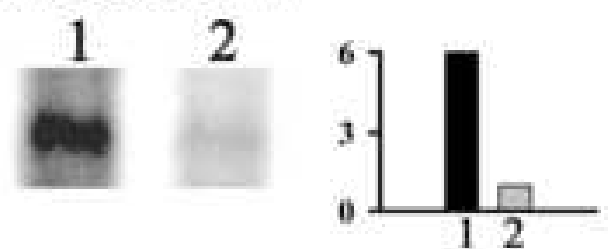

NCU00212

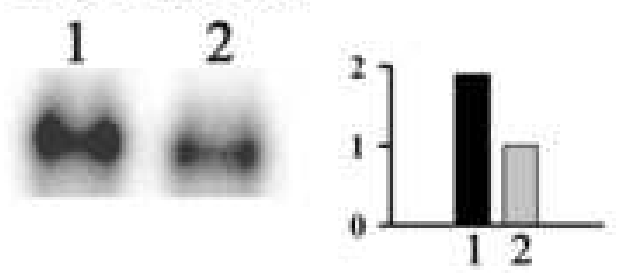

NCU01633

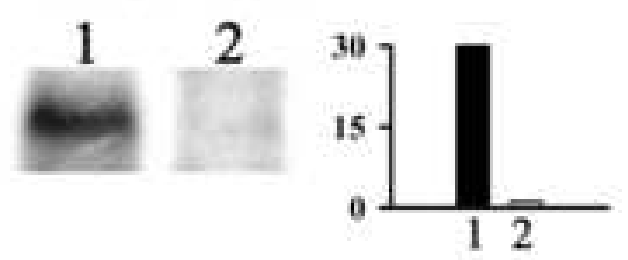

NCU08332

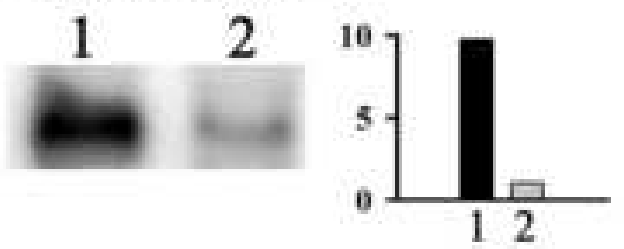

NCU03004

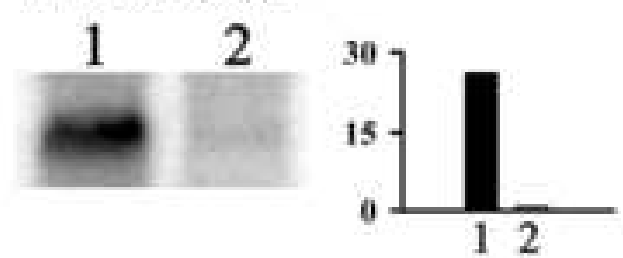

NCU07930

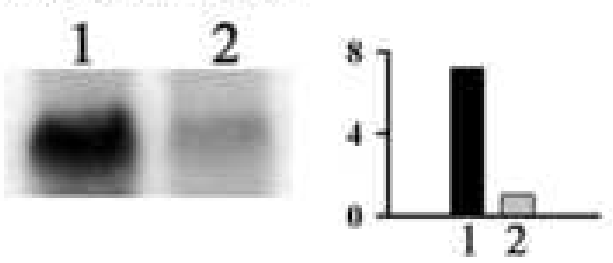

NCU01635

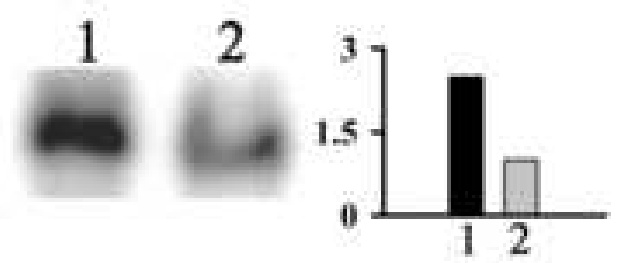

rRNA 